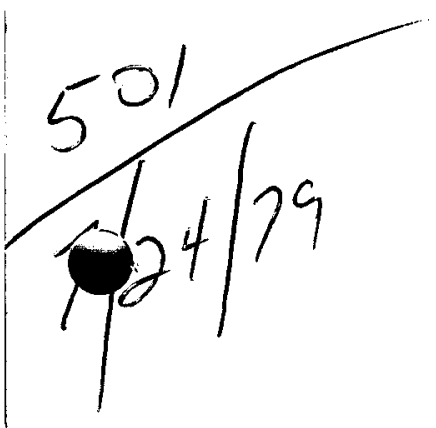

th. $7893 \begin{gathered}\text { LBL-8617 } \\ \text { GSRMP-3 } \\ \text { UC- } 660\end{gathered}$

\title{
Guidelines Manual for Surface Monitoring of Geothermal Areas
}

\author{
C. J. Van Til \\ Woodward-Clyde Consultants \\ Three Embarcadero Center \\ San Francisco, California
}



May 1979

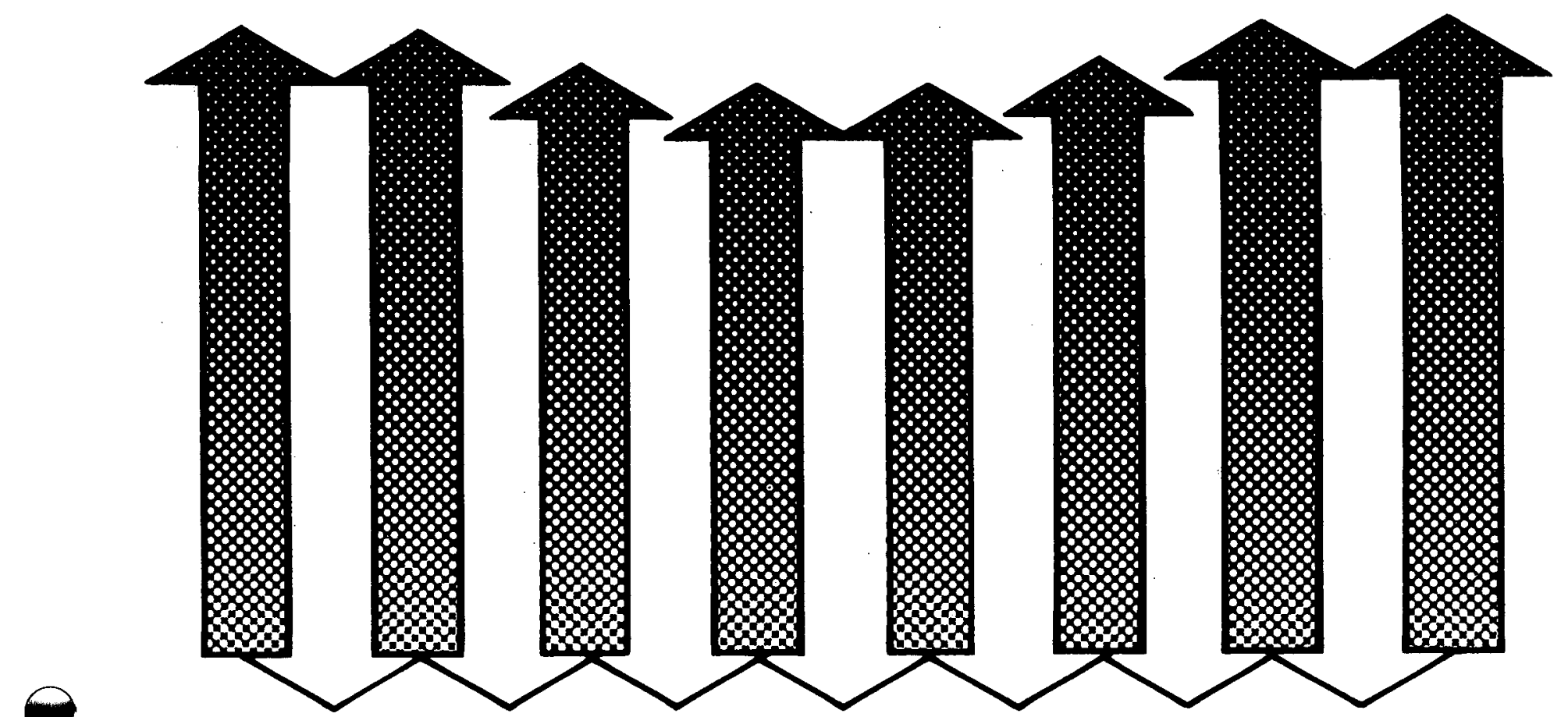

Earth Sciences Division Lawrence Berkeley Laboratory University of California 


\section{DISCLAIMER}

This report was prepared as an account of work sponsored by an agency of the United States Government. Neither the United States Government nor any agency Thereof, nor any of their employees, makes any warranty, express or implied, or assumes any legal liability or responsibility for the accuracy, completeness, or usefulness of any information, apparatus, product, or process disclosed, or represents that its use would not infringe privately owned rights. Reference herein to any specific commercial product, process, or service by trade name, trademark, manufacturer, or otherwise does not necessarily constitute or imply its endorsement, recommendation, or favoring by the United States Government or any agency thereof. The views and opinions of authors expressed herein do not necessarily state or reflect those of the United States Government or any agency thereof. 


\section{DISCLAIMER}

Portions of this document may be illegible in electronic image products. Images are produced from the best available original document. 


\section{LECAL NOTICE}

This report was prepared as an account of work sponsored by the United States Government. Neither the United States nor the United States Department of Energy, nor any of their employees, nor any of their contractors, subcontractors, or their employees, makes any warranty, express or implied, or assumes any legal liability or responsibility for the accuracy, completeness or usefulness of any information, apperatus, product or process disclosed, or represents that its use would not infringe privately owned rights.

Printed in the United States of America Available from

National Technical Information Service

U.S. Department of Commerce

5285 Port Royal Road

Springfield, VA 22161

Price Code : A07 


\section{GUIDELINES MANUAL FOR SURFACE MONITORING OF GEOTHERMAL AREAS}

Prepared for

University of California

Lawrence Berkeley Laboratory

Berkeley, California

By

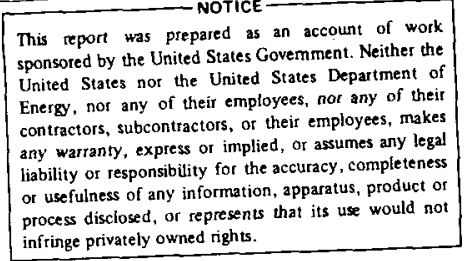

C. J. Van Til

Woodward-Clyde Consultants

Three Embarcadero Center

San Francisco, California

November, 1978

Geothermal Subsidence Research 
This report was prepared by Woodward-Clyde Consultants, Western Region, San Francisco, California, under Lawrence Berkeley Laboratory Purchase Order No. 3029902. The contract was initiated under the Geothermal Subsidence Research program, being conducted by Lawrence Berkeley Laboratory of the University of California, under the auspices of the Division of Geothermal Energy of the U.S. Department of Energy. The contract was administered under the technical direction of Dr. T. L. Simkin, Mr. W. Stromdah1, and Mr. J. Noble. The contracts officer was Mr. H. A. Todd.

This report is for work completed during the contract period of November 10, 1977 to October 31, 1978. This report was submitted by the author on August 11, 1978.

The author wishes to acknowledge the direction and review of this study by Dr. Ulrich Luscher, Woodward-Clyde Consultants' Principal-in-Charge for this project. He also wishes to thank Mr. Don Poulter, Ms. Linda 0'Donnel1, Dr. Ram Kulkarni, Mr. K. Weaver, Mr. John E. O'Rourke, and Ms. Barbara B. Ranson, all of Woodward-Clyde Consultants, for their technical assistance in the conduct of the study and constructive review during the preparation of this report. 
1.0 INTRODUCTION

1.1 Background

1.2 Monitoring Objectives and Purposes

1.3 Scope and Limitations of the Manual 4

2.0 PRELIMINARY INVESTIGATION 6

2.1 Basic Information Gathering 7

2.2 Initial Site Inspection 8

2.3 Plan for Additional Information 8

2.4 Field Investigation 9

2.5 Report of Preliminary Investigation 9

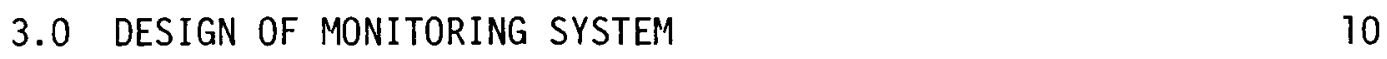

3.1 Defining the Site 10

3.2 Regional Survey Network 11

3.3 Local Survey Network 11

3.4 Special Monitoring 12

$\begin{array}{ll}4.0 \text { MONITORING OPERATIONS } & 14\end{array}$

4.1 Construction 14

4.2 Scheduling 14

4.3 Measurements 16

4.4 Data Handling 17

\section{APPENDICES}

A - CHARACTERISTICS OF NON-GEOTHERMAL SUBSIDENCE

A-1

A-1 Groundwater Withdrawal A-1

A-2 0 il or Gas Withdrawal $\quad A-6$

A-3 Tectonism A-8

A-4 Collapsing Soils (Hydrocompaction) A-8

A-5 Soil Oxidation A-10

A-6 Underground Mining A-10

A-7 Landslides A-13 
B - CHARACTERISTICS OF GEOTHERMAL SUBSIDENCE

$B-1$ Causes of Geothermal Subsidence $B-1$

$B-2$ Subsidence Potential of Geothermal Fields B-4

B-3 Ground Movements Associated with Geothermal

Subsidence B-6

B-4 Magnitudes of Subsidence $B-7$

B-5 Areal Extent of Geothermal Subsidence B-7

C - GUIDELINES FOR SPECIFICATIONS FOR MONITORING SUBSIDENCE C-

$\mathrm{C}-1$ Objective of Specifications $\mathrm{C}-1$

C-2 Useful measurements for Monitoring Subsidence $\mathrm{C}-1$

$\mathrm{C}-3$ Range and Accuracy of Measurements $\mathrm{C}-1$

C-4 Monitoring Networks C-6

D - INSTRUMENTS FOR MONITORING D-1

D-1 Surveying Instruments $D-1$

D-2 Special Monitoring Instruments D-4

D-3 Bench Marks D-17

D-4 Instrument Ratings D-19

E - FORMATS FOR DATA PRESENTATION E-1

E-1 Vertical Measurements E-1

E-2 Horizontal Measurements E-4

E-3 Additional Data E-9

F - STATISTICAL ANALYSES

$\mathrm{F}-1$ Number of Pre-Production Observations $\mathrm{F}-1$

$\mathrm{F}-2$ Averaging of Observations F-3

F-3 Analyzing Subsidence Data F-4

G - REFERENCES AND SELECTED BIBLIOGRAPHY G-1 


\subsection{INTRODUCTION}

\subsection{BACKGROUND}

In any discussion of geothermal subsidence, it is important to consider also the subsidence resulting from other sources. There are two primary reasons for such consideration. First, ground movements from one or more other sources may occur in a geothermal area. For example, at the Geysers in California, tectonism, landslides, and geothermal fluid withdrawal all contribute to ground movement. To identify the contribution of each source to the total subsidence, the characteristics of ground movements from each source must be understood. A second reason for consideration of non-geothermal sources of subsidence is that data on geothermal subsidence is scarce. Examination of subsidence processes which share some common features, particularly those involving fluid withdrawal, may provide some insight into the nature of subsidence from geothermal production.

Ground movements have been recognized as having resulted from the following non-geothermal sources: groundwater withdrawa1, oil and gas withdrawal, tectonism, collapsing soils (hydrocompaction), soil oxidation, underground mining, landslides, and slope creep. A discussion of the characteristics of the ground movements resulting from these non-geothermal sources is presented in Appendix A.

Experience has demonstrated that the subsidence in an area may be the result of two or more sources acting simultaneously. For example, in the Wheeler Ridge area of the San Joaquin Valley, California, ground movement resulted from the combination of groundwater withdrawal, extraction of $0 i 1$ and gas, tectonism, and hydrocompaction. Vapor or liquid-dominated geothermal areas are usually associated with magmatism high in the earth's crust and with tectonic plate boundaries, so tectonic movements in geothermal areas are likely. Landslides may be associated with a geothermal area of rugged topography such as the Geysers. Geopressured fields often contain valuable 
quantities of methane and are found near petro?eum producing areas; thus oil and gas withdrawal could contribute to subsidence in these areas. The other potential sources of subsidence (hydrocompaction, oxidation of organic soils, and underground mining) have not been reported as occurring in geothermal resource areas. They are associated with specific soil or rock formations and should be readily identifiable.

The major process which may cause subsidence in geothermal areas is considered to be loss of pore space due to fluid withdrawal. This process may effect both intergranular (primary) pore space and fracture (secondary) space. This process is readily explained by the theory of effective stress, which states that the effective downward stress carried by the rock or soil structure is equal to the geostatic pressure (due to the combined weight of overlying rock and interstitial water) minus the fluid pressure. Thus, a decrease in fluid pressure caused by the removal of fluids by production results in increased effective stress and leads to compaction of the layers from which the fluids were removed. The decrease in volume in the compacted layers is reflected as subsidence of the overlying strata and of the ground surface. Compaction of intergranular pore space is considered to account for the major portion of subsidence in geothermal areas, but experiments on rock core samples indicate that an increase in effective stress may also reduce the volume of fracture pore space.

Subsidence may result from thermal contraction associated with reservoir cooling; and earthquake shaking can contribute to the compaction of porous, unconsolidated materials by facilitating rearrangement of grains. Thermal contraction would probably be minor because of the low coefficients of thermal expansion of the materials involved and the small changes in average temperature which result from production. Since most geothermal areas are located near the boundaries of major crustal plates, they are more likely to experience seismic shaking than other fluid resource areas as a group. A more detailed discussion of the characteristics of geothermal subsidence is presented in Appendix $B$. 
The geothermal resources of the United States are an important potential source of energy. The production of that energy involves withdrawal of fluid from the ground. In many areas of $0 i 1$, gas, or water production, subsidence has accompanied fluid withdrawal. In New Zealand, three producing geothermal fields have all experienced subsidence. It is reasonable, therefore, to expect subsidence to result from withdrawal of geothermal fluids as U. S. geothermal resources are developed.

Surface subsidence due to all sources has caused a considerable amount of damage around the world. In excess of $\$ 100$ million in remedial work was carried out as a result of subsidence due to petroleum production at the Wilmington oil field in California. Subsidence has also hampered industrialization and development in and around subsiding areas. Because of the important economic consequences of subsidence, serious consideration must be given to establishing programs of subsidence monitoring for all geothermal fields.

\subsection{MONITORING OBJECTIVES AND PURPOSES}

The fundamental objective of a monitoring program as described in this manual is to quantify the magnitude and direction of surface movements which may occur in a geothermal reservoir area immediately prior to, during, and immediately following the removal of geothermal fluids for the production of energy.

A monitoring program may be established for one or more purposes. Several possible purposes include:

1. The satisfaction of legal requirements for monitoring instituted by governmental authorities with jurisdiction in the area.

2. The protection of environmental features, such as streams, parks, forested areas, wildlife habitat, etc., which may be adversely affected by subsidence. 
3. The protection of man-made structures, such as irrigation or drainage canals, dams, power plants, buildings, power lines, communication towers, roads, railroads, etc., which may be damaged by subsidence.

4. The collection of evidential data for enforcement purposes.

5. A check of engineering design features intended to minimize the effects of subsidence.

6. Research, for example, in the development of monitoring techniques, or in operational aspects of the geothermal field, including relation between rate of subsidence and rate of fluid withdrawal, rate of subsidence vs. rate of fluid reinjection and relationships between subsidence and temperature regime changes.

Other purposes may be considered in making the decision whether or not to establish a monitoring program. No further elaboration of purposes will be presented here, since it is assumed in preparing this manual that the decision to monitor has already been made. However, the purpose of the program is an important consideration in its design, since certain aspects of the program will be affected by the purpose to be served by the program. For example, if one of the purposes is research, a greater number or different arrangement of monuments might be used, or measurements might be taken with greater frequency. In any event, the purpose which the program is to serve should be clearly understood before the design is initiated.

\subsection{SCOPE AND LIMITATIONS OF THE MANUAL}

This manual is intended to provide guidelines for the establishment of a program for the monitoring of surface movements associated with the production of energy from a geothermal source. Included within the scope of these guidelines are: the preliminary investigations which must be made to obtain the necessary data for design of the program; the design of the monitoring program; and the operation of the program, including data handling and analysis. Not included within the scope of these guidelines are the decision making processes involved in deciding whether 
or not to monitor, and in deciding what actions, if any, are indicated by the results of the monitoring program. Also not included are subsurface monitoring, although subsurface monitoring should be considered, either as an integral part of the surface monitoring program, or as a separate program.

Since the purpose of the monitoring program, as well as the characteristics of the site, will affect its design, a standard monitoring program applicable to all sites cannot be prepared. However, subsidence monitoring programs for geothermal production sites can be described in a series of logical steps. It is the purpose of this manual to describe these logical steps, and to point out the site-specific information which is required during each step in order to arrive at an adequate program for the site. The format of this manual recognizes by major section headings the three major steps in establishing the program: Preliminary Investigation, Designing the Monitoring System, and Monitoring Operations. The guidelines are presented in brief narrative descriptions generally indicating their logical sequence of application. Where amplified descriptions and additional details are indicated, they are presented in appendices or by references. 


\subsection{PRELIMINARY INVESTIGATION}

The design and operation of a subsidence monitoring program require a competent team supervised by experienced professionals. For example, the team might be headed by a civil engineer with surveying, instrumentation, and data analysis experience, assisted by a structural geologist, preferably having been associated with pre-production investigations of the field to be monitored. The geologist supplies the interpretation of site geology required to establish such design input as: probable extent of the area of subsidence; estimates of probable order of magnitude of subsidence from each likely source; and susceptibility to lands]ides. The engineer provides the knowledge required for: design of the monitoring system, including selection of suitable instrumentation; for operation of the monitoring system; and for analysis of the monitoring data. Ideally, the preliminary investigation should be conducted under the supervision of the same professionals who will be in charge of design and operation.

Before a monitoring system can be designed, certain information regarding the site must be obtained. A considerable amount of the necessary information for most sites will be readily available. However, some limited field investigation will usually be required to supplement or to verify and update information obtained from published literature or other available sources. In the following sections, the types of information required are presented and the probable sources for obtaining such information are listed. Also presented are the reasons for obtaining the information in terms of the probable use which will be made for it in the design or operation of the monitoring system. For purposes of this discussion the Preliminary Investigation is recognized as consisting of five steps, as follows: (1) Basic Data Gathering, (2) Initial Site Inspection, (3) Plan for Additional Information, (4) Field Investigation, and (5) Report of Preliminary Investigation. Because the investigation must be tailored to the site, the lists of the types of information required are not necessarily all-inclusive, and the investigator should be alert for unusual information which may affect the design or operation of the monitoring system. 


\subsection{BASIC INFORMATION GATHERING}

Following are examples of the most important types of information which should be obtained, the major sources of such information, and the primary purposes for which the information will be used.

a. Geologic maps and reports; U. S. Geological Survey (USGS), State geologic agencies, and university geology departments; characteristics and location of geologic formations in and surrounding the reservoir area.

b. Topographic maps, recent and historical; USGS; elevations, slopes, drainage pattern, locations of roads, railroads, bridges, dams, reservoirs, canals, and other significant construction, and location of survey monuments. (Comparison of recent and historical maps may indicate whether gross changes in elevations or slopes have occurred.)

c. Aerial photographs, recent and historical; USGS National Cartographic Information Center, aerial survey companies; details of surface features not obtainable from topographic maps, e.g., vegetation, rock outcrops, smal1 streams, and structures. (Comparison of recent and historical photographs may identify landslides or other surface changes not identifiable on topographic maps.)

d. Soils maps and reports; U. S. Department of Agriculture Soil Conservation Service (Washington D.C. office, and local offices); properties of soils for use in determination of types and location of monuments.

e. Climate and weather records; U. S. Weather Service; data on frost penetration, precipitation, stream flows, floods, and high water levels for use in determination of location of monuments and scheduling of surveys. 
Much of the above information is available from university or other technical libraries. In addition to the above rather standard information, the information which might be available from local sources should not be ignored. First of 211 , a considerable amount of site-specific information will have been accumulated during studies to locate and develop the site. Also, special studies may have been made in the area for design and construction of highways, railroads, airports, canals, dams, bridges, or buildings. Interviews should be conducted with personnel likely to have pertinent information not published, for example, city, county, or state highway personnel concerned with highway design, construction, or maintenance in the area. Records of water supply well levels over the previous years may be of significant value.

\subsection{INITIAL SITE INSPECTION}

Once the major portion of the basic data has been obtained, an initial site inspection should be made. The inspection should be planned to accomplish specific purposes, such as checking or confirming information developed from the basic information, and obtaining information not included in available documents. The inspection should be made by one or more persons, selected on the basis of qualifications in regard to the type of information involved. Maps and aerial photographs should be used to plan the inspection and as guides during the conduct of the inspection. Field notes and sketches may also be made directly on maps or aerial photographs.

Typical of the information obtained from the site inspection are: for structures - type of foundation, and general structural condition; for soils - confirmation as to type and condition; and for survey monuments confirmation as to location and accessibility.

\subsection{PLAN FOR ADDITIONAL INFORMATION}

If it is determined that certain needed information is not available in the literature and cannot be obtained by the site inspection, a plan should be prepared for obtaining this information by other means. The most likely means are through a limited field investigation. For example, if needed information on soil depth or subsurface condition is not available, a field investigation might be planned to obtain the information by mechanical boring or test pits, or by hand augering. Planning for a field 
investigation should include: determining precisely what information is needed, assuring that the information cannot be better obtained by other means, and specifying the manner in which the information should be obtained in the field.

\subsection{FIELD INVESTIGATION}

This step consists of conducting the field investigation as specified in the plan.

\subsection{REPORT OF PRELIMINARY INVESTIGATION}

Following completion of the investigation a report should be prepared. If a formal report is not required by a regulatory agency or by contract agreement, an informal report should be prepared for use in design of the monitoring program. It should include at least: a tabulation of all data obtained; copies of all maps and aerial photographs; extracts of pertinent information from published reports, with complete reference to the report from which obtained; results obtained from the site visit and field investigation, including data and field notes; and explanatory notes, conclusions, and recommendations regarding any of the information obtained. 


\subsection{DESIGN OF MONITORING SYSTEM}

Guidelines for the design of the monitoring system are presented in the following sections as four basic tasks: defining the site, regional survey network, local survey network, and special monitoring.

\subsection{DEFINING THE SITE}

Before a monitoring system can be designed it is necessary to determine the area which should be covered by the system. The first step is to determine the probable extent of the geothermal reservoir, and of the area which may be subject to subsidence as a result of withdrawal of geothermal fluids from the reservoir. This information should be available from information developed during the course of the investigations which were made to locate the geothermal field and to arrive at a decision regarding its development. Any interpretations of this information should be made by a geologist with the necessary specialized background.

A second step is to arrive at decisions as to whether subsidence from non-geothermal sources is likely to occur, and, if so, the probable source, magnitude, and areal extent of such subsidence. These decisions are usually based on historical records or on indirect evidence that subsidence probably has, or has not, occurred in the recent past.

The third and finat step in this task is the actual establishment of the boundaries for the monitoring system. These boundaries will usually include only the area expected to be affected by geothermal production. However, if subsidence from another source is expected to occur in a larger area which includes some or all of the geothermal area, consideration should be given to extending the monitoring area to include at least a portion of the area expected to be affected only by the non-geotherma source. This will assist in separating geothermal movements from baseline movements, as discussed later. 


\subsection{REGIONAL SURVEY NETWORK}

The regional network is intended to be the stable base from which all determinations of movements are made. Although, in theory, one bench mark may be all that is required, it is suggested that consideration be given to the establishment of a minimum of three for additional convenience and greater reliability. The two major criteria to be considered in the selection and establishment of bench marks in the regional network are:

(1) location outside of the area assumed to be subject to movement associated with subsidence resulting either from geothermal production or from other sources; and (2) accessibility to survey tie-ins to the local network, with consideration given to distances, intervening terrain features or structures, and land use and ownership of property to be traversed.

Also required in the design of the regional network are: the determination of the specific location of any bench marks to be established; obtaining the necessary permission to place the bench marks at the selected locations, and assuring that right of entry may be obtained for placement of the bench marks and for future access for survey tie-ins; and preparation of specifications for initial surveying services for the regional survey, including the specifications for bench mark construction.

Appendix $C$ presents guidelines for the preparation of specifications for regional survey networks, including required survey accuracy. Appendix $D$ discusses the characteristics of instruments applicable to use in regional survey networks, and the requirements for survey bench marks.

\subsection{LOCAL SURVEY NETWORK}

The local survey network consists of permanent bench marks within the boundaries of the area to be monitored. This design task-includes the location of the bench marks to provide effective coverage of the area at a reasonable cost, and the selection of the type of bench mark to be used.

The location and spacing of bench marks will depend on the terrain and the purpose of the monitoring program. Where no special features or structures exist, a bench mark spacing on the order of 500 to 800 meters should be 
satisfactory. Additional bench marks, or closer spacing, should be provided where loss of a bench mark would be critical. Closer spacing might be required also where geologic structure is complicated, or where more detailed information is desired, such as for research purposes. Considerably wider spacing could be used where terrain and geologic structure are uniform or where more detailed information regarding movements is not required.

The location of bench marks should be such as to minimize the possibility of disturbance, and to be conveniently accessible to survey crews. Bench marks may be disturbed or destroyed by construction or other activities of man, or by natural forces such as landslides, soil creep, frost heave, expansive soils, or flooding.

Appendix $C$ presents further guidelines for the preparation of specifications for local survey networks, including required survey accuracy. Appendix $D$ discusses the characteristics of instruments applicable to use in local survey networks, and the requirements for survey bench marks.

\subsection{SPECIAL MONITORING}

The area-wide monitoring which is accomplished by means of the local network of bench marks may need to be supplemented by more comprehensive or precise monitoring at a point or over a limited area. Such special monitoring may be accomplished by setting additional monuments within the local network or by the use of certain special-purpose instruments. Installation of one or more additional monuments should be considered at special locations, such as at well-heads or on structures which are particularly susceptible to damage by ground movements. Special purpose instruments which have particular applications to surface monitoring are of three types: extensometers, tube profile devices, and tiltmeters.

Extensometers are used to determine the change in distance between two relatively closely-spaced points. Examples of use are for monitoring across known fault lines or surface cracks. 
Tube profile devices have applications in the monitoring of vertical. movements in inaccessible locations, such as under dams or other relatively large and heavy structures. They should also be considered for use in congested areas or other areas of inconvenient access, such as well fields, buildings, or other structures.

Tiltmeters may be used to monitor movements in local areas. One major advantage of the tiltmeter is that movement may be detected by reading of a single instrument, without tie-in to other monuments, such as would be required for survey techniques.

Special purpose instruments and guidelines for their use in monitoring are discussed in detail in Appendix $D$. 
Guidelines for the operation of a monitoring system are presented in the following sections. The following four tasks have been included as operations functions: construction, scheduling, measurements, and data handling. Construction is included here because it will be performed in connection with initial survey measurements and is difficult to separate from operations. Also, although scheduling might be considered to be a design function, it is included with operations because it is almost certain that any initial schedule would be tentative and that scheduling will be subject to changes as operations continue.

\subsection{CONSTRUCTION}

Construction of the system includes the installation of a 11 bench marks for the regional and local survey networks at the specified locations and according to the construction specifications; and the installation of all special instrumentation. Measurements in the first survey round are conducted in conjunction with construction. This survey establishes the initial elevation and horizontal position of all bench marks. Initial readings are also made on the special instruments at the time of installation.

Also established at this time are the formats for tabulation of the data from the surveys and special instruments. Formats for recording of survey data in the field and for the associated calculations to arrive at elevations and positions are adequately covered in surveying manuals and textbooks and are not repeated here. Guidelines for presentation of the results of the monitoring surveys are presented in Appendix $E$.

\subsection{SCHEDULING}

Because of the many unknowns at the beginning of the monitoring period, it is not feasible to establish a rigid monitoring schedule for the production life of the geothermal field. The rate of subsidence, the total amount of subsidence, and even whether subsidence will occur, all 
affect the monitoring schedule, but must be predicted from very limited data and little experience at this time. Predicted rates of withdrawal and of total withdrawal of geothermal fluids are almost certain to change as production proceeds, as the characteristics of the reservoir become better known, and as the demands for power from the facility fluctuate.

However, it is essential for planning purposes that a tentative schedule for monitoring be established as early as possible, with provisions for modification of the schedule as production proceeds. Information obtained in previous steps will be helpful in establishing the tentative schedule. The schedule is built around three points: (1) the earliest time at which installation of the monitoring equipment can be expected to be completed; (2) the planned initiation of substantial withdrawal of geothermal fluids (beginning of production); and (3) the end of the planned production cycle. Although each round of measurements in the monitoring program is conducted in essentially the same manner as all others, the program may be divided into three phases on the basis of the use made of the data obtained: (1) the pre-production, or base-line phase; (2) the production phase; and (3) the post-production phase.

The pre-production phase is primarily for the purpose of establishing a base-line against which later measurements will be compared. The preproduction phase may also serve the important secondary purposes of confirming the adequacy and workability of the monitoring program and equipment; training of crews in the operation of equipment and familiarizing them with procedures; and making any changes in program or equipment based on initial operations. The importance of establishing the rate of base-line movements dictates , that the pre-production period be as long as practical, although a pre-production monitoring period of more than about two years may seldom be feasible. Guidelines for scheduling of pre-production monitoring are presented in Appendix $F$, Section 1.

The production phase of monitoring is primarily for the purpose of detecting any movements which may be attributable to the withdrawal of geothermal fluids, and estimating the detrimental effects which such movements have had, or might be expected to have, on environmental or man-made features. 
(Actions which should be taken in the event of detrimental effects, or prediction of detrimental effects are outside the scope of this manual.) It is suggested that the initial measurement cycle be scheduled approximately six months after the beginning of production, and at about six-month intervals thereafter if appreciable movements are detected. If no movement is detected during the first four or five measurement cycles in the production period, it is suggested that the interval be lengthened to about 12 months. As long as no movements are detected, the 12 month cycle may be continued, but it should revert to the 6 month cycle at any time that movements are detected. A special monitoring cycle should be considered following a period of unusual seismic activity, or when there is visual evidence that accelerated movements may have occurred.

Monitoring is continued into a post-production phase because there is evidence that surface movements may lag appreciably behind the time at which the movement is generated at a subsurface source. It is suggested that the interval between measurement cycles at the end of the production phase should be continued into the post-production phase. Monitoring may be discontinued after two or three years if no movement has been detected during that period, or one year after the rate of movement at the end of the production period has essentially stopped.

This monitoring schedule is applicable only to the local survey net and to special monitoring instruments. The monuments in the regional network are assumed to be stable and frequent checks are not performed. It is suggested that they be checked against one or more established bench marks at a considerable distance at intervals of five to ten years.

\subsection{MEASUREMENTS}

This step includes performing the monitoring measurements in the field according to the tentative schedule previously established, and tabulating the data according to the established format. As discussed in the previous section, the results obtained will be used to judge whether the monitoring schedule should be changed. 
In addition to the scheduled measurements, it is recommended that a $10 \mathrm{~g}$ be kept of all events which may be of significance to rate of subsidence, such as: start of geothermal production, rates of fluid withdrawal, earthquakes, landslides, rock falls, and initiation of ground cracking or cracks in structures. Consideration should be given to installation of additional bench marks or special instrumentation to monitor unexpected movements. For instance, appearance of ground cracking might warrant installation of extensometers to monitor the rate of movement.

\subsection{DATA HANDLING}

As mentioned in a previous section, guidelines for presentation of the results of the monitoring surveys are presented in Appendix $E$. Included in Appendix $E$ are: a suggested format for use in tabulation of bench mark elevations, of the differences in elevation between successive elevation determinations, and of the total difference in elevation for the monitoring period; a simple example of how elevation differences may be used to plot subsidence "contours"; an example of a method of graphical presentation of the results of a level survey; a suggested format for tabulation of results of surveys for determination of horizontal movements; and a simplified example of a method of graphical presentation of horizontal movements. These examples are guidelines for recording the monitoring data, and for plotting to assist in visualizing the data.

To satisfy the purposes of monitoring it is necessary to determine the surface movements which have resulted from the withdrawal of geothermal fluids. If no measurable movements occur prior to geothermal production, the determination is relatively simple, since, barring any unusual occurrences, al1 movements determined after initiation of production are assumed to result from the production. If movements are measured during the pre-production period, these movements are extrapolated into the production period to form the "baseline". The movements attributable to geothermal sources are then assumed to be the total measured movements after production, minus the baseline movements. Although this approach is simple, its application may not be so simple because movements cannot be expected to be the same at all bench marks and the rate of movements will vary with time. Plotting of results (see Appendix E) may be helpful in visualizing the data, but a statistical approach will usually be indicated. 
The basic statistical approach applicable to this problem is to perform a regression analysis for the pre-production data; to use the resulting regression model to estimate the baseline movement at some time, $t$, during the production period; and to compare this base line estimate with the measured total movement at that time. The difference between the estimated base line value and the measured value is the assumed value of movement associated with geothermal production. If this difference is smal1, it is possible that the base line movements have deviated from the predicted model. A simple statistical approach may be used to determine the probability that a measured production value belongs to the family of movements recorded before production, i.e., that no increase in movement has resulted from geothermal production. The applicable statistical procedures and a numerical example are presented in Appendix F, Section 3. Also presented in this Appendix is a method for determination of the statistical correlation between measured rate of subsidence and rate of geothermal production.

Included as a data analysis function should be provision for periodic summary reports, including those which might be required by regulatory agencies, and for a final report after completion of monitoring. 
In this Appendix, the characteristics of ground movements from the following sources are briefly reviewed:

- groundwater withdrawal

- oil or gas withdrawal

- tectonism

- collapsing soils (hydrocompaction)

- soil oxidation

- underground mining

- landslides and slope creep

\section{A. 1 GROUNDWATER WITHDRAWAL}

Groundwater withdrawal has produced subsidence in the San Joaquin Valley, California; Tokyo, Japan; Venice, Italy; and many other areas around the world (Poland and Davis, 1969). Subsidence in the San Joaquin Valley, perhaps the best documented case, has affected roughly 9000 square kilometers of farmland (Lofgren, 1969). As of 1969 the maximum subsidence in the San Joaquin Valley was roughly $9 \mathrm{~m}$. This amount is equalled only by subsidence in Mexico City and at the Wilmington oil field. In groundwater subsidence areas, the areas of maximum withdrawal tend to experience the greatest downward movement, with a bowl-shaped depression forming over the area of withdrawal. The magnitude and contours of the subsidence trough are dependent on the thickness of the compressible deposits in a given location.

The deposits associated with groundwater subsidence tend to be unconsolidated to semi-consolidated clastic deposits of alluvial or lacustrine origin. They are all confined aquifers containing high permeability coarse-grained strata with low permeability fine-grained aquitards (Poland, 1969). The fine-grained compressible layers are responsible for most of the subsidence (Lofgren, 1969). 
The mechanism of groundwater subsidence is primarily consolidation of the aquitards. Lowering of the groundwater pressure by pumping causes an increase in effective stress in the aquifer and associated aquitards. This stress increase causes some small elastic compression of the coarsegrained soils. The behavior of the fine-grained soils is more complex. The aquitards will first compress as an overconsolidated soil until the preconsolidation pressure is reached. This compression is small and elastic, i.e., it can be substantially regained by unloading the soil. Any subsequent compression due to stresses greater than the preconsolidation pressure will occur as virgin compression. Most of the pore space lost during virgin compression is irrecoverable. Typical behavior of a fine-grained soil under loading and unloading is shown on Figure A-la. This behavior is reflected in field records, as shown in Figure A-1b. During an annual cycle of pumping and recovery, when the loads due to the pore pressure decline are applied for only a limited time, only a small amount of the potential consolidation occurs -- on the order of $5 \%$ to $8 \%$ (Riley, 1969). This complicates interpretation of the data and prediction of subsidence. Subsidence movements in areas of seasonal overdraft tend to show a step-like pattern (Figure A-2), with no compression or a slight rebound occurring during the rainy season. The lack of significant rebound is due primarily to the difference between the pore space lost during virgin compression and that recovered during rebound (Figure $A-1 a$ ).

Ground cracking may accompany groundwater subsidence. Fissuring or faulting has been observed associated with groundwater withdrawal in Arizona; California; Ráft River Valley, Idaho; Houston-Galveston, Texas; and Las Vegas, Nevada (Holzer, 1976). The mechanism of ground cracking is controversial. Several theories have been advanced. Ground fissures are postulated to develop from tension cracking due to bending (Lee and Shen, 1969), from differential subsidence across discontinuities or across faults in the basement rock, or from horizontal seepage stresses (Lofgren, 1969).

Data from selected groundwater subsidence areas are shown in Table A-1. 




FIGURE A-1a: IDEALIZED BEHAVIOR OF FINE-GRAINED SOIL UNDER DRAINED LOADING

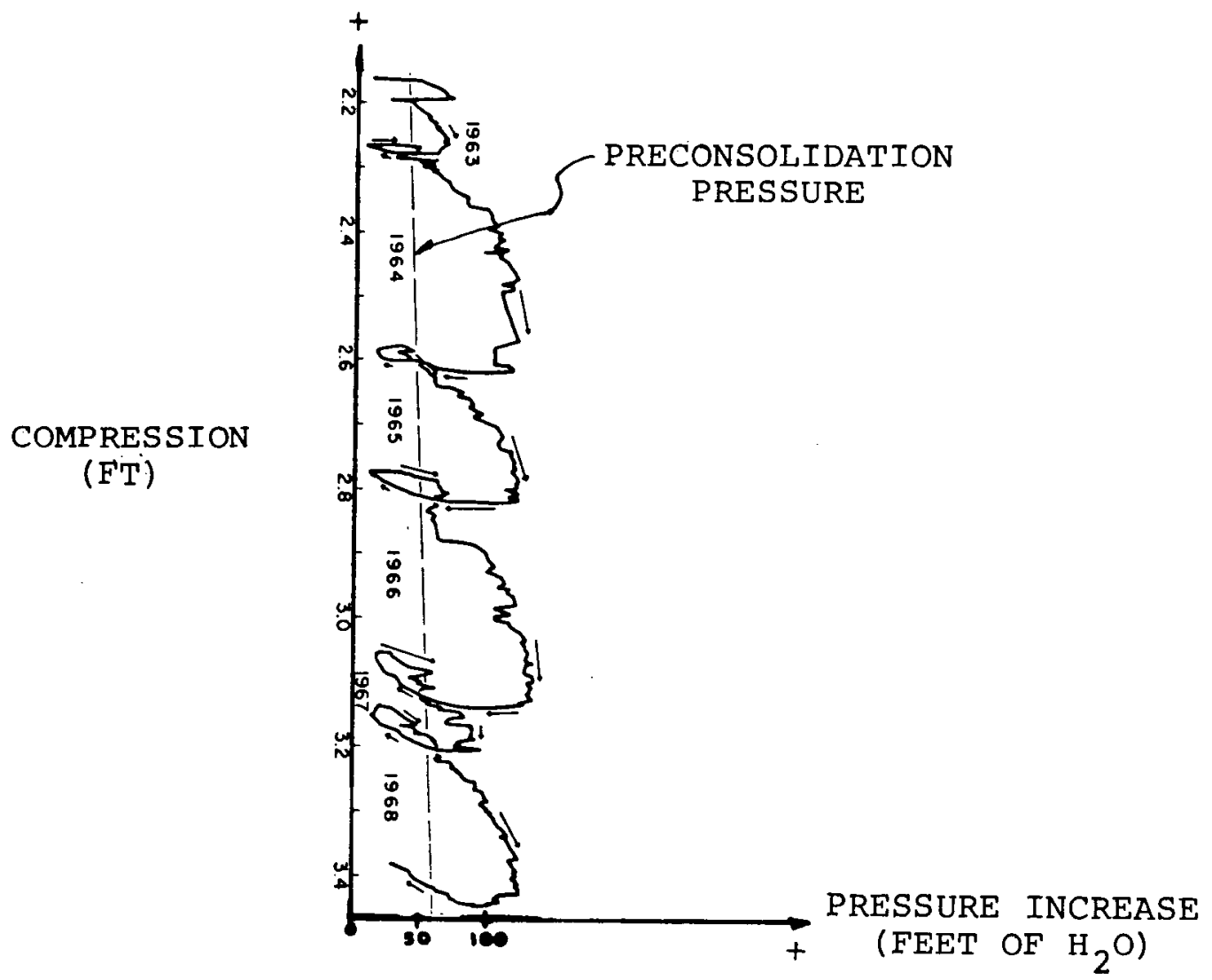

FIGURE A-1b: FIELD BEHAVIOR OF CONFINED AQUIFER SYSTEM AT PIXLEY, CALIFORNIA (Riley, 1969) 

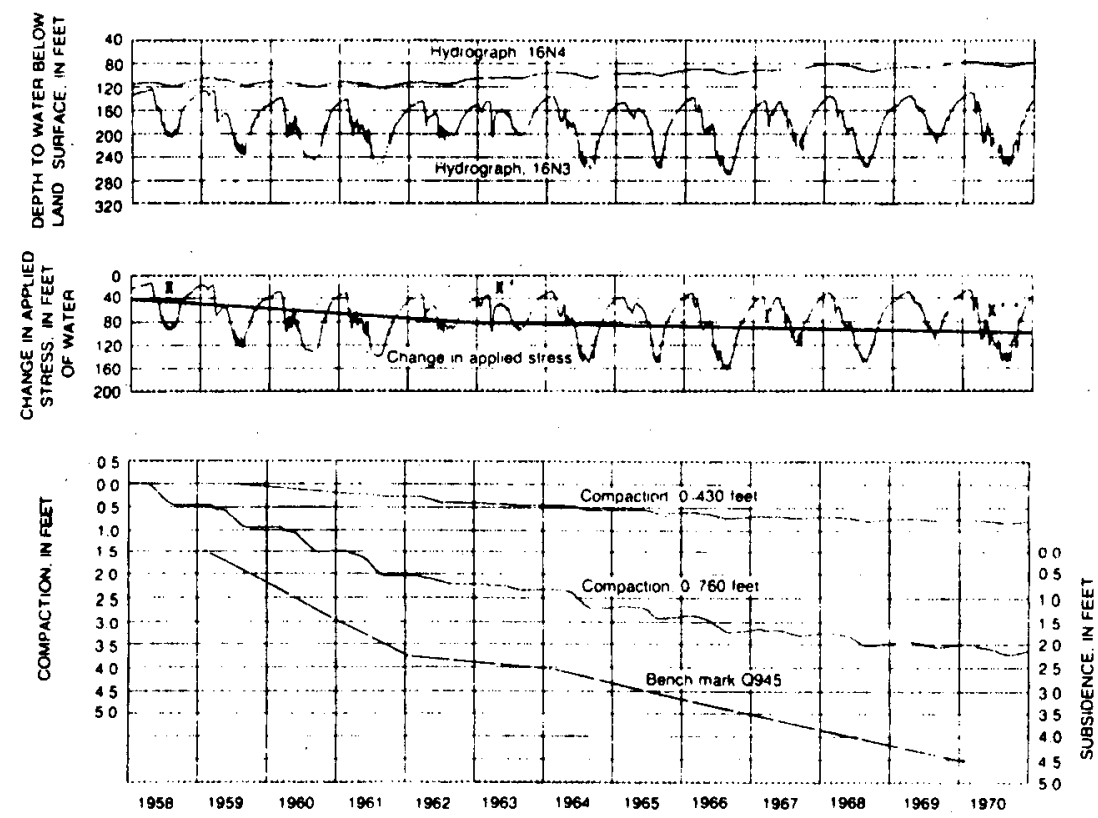

(Lofgren, 1976)

FIGURE A-2 - STEP-LIKE COMPRESSION IN CONFINED AQUIFER NEAR PIXLEY, CALIFORNIA 
TABLE A-1 - SELECTED DATA FROM GROUNDWATER SUBSIDENCE AREAS

(from Atherton et al, 1976)



- not Measured Sources: Poland, 1969; Poland and Davis, 1969 


\section{A.2 OIL OR GAS WITHDRAWAL}

Subsidence has been recorded at only a few of the many oil and gas fields world wide. Most of these are near a body of water, and subsidence has caused extensive flooding (Poland and Davis, 1969). It is likely that other fields have undergone subsidence, but it has not been measured. The areas of notable subsidence include the Wilmington oil field, California; the Goose Creek oil field, Texas; the gas fields of the Po Delta, Italy; the oil fields at Lake Maracaibo, Venezuela; and the gas fields at Niigata, Japan.

Subsidence appears to be a result of the removal of water and sand, as well as oil and gas (Poland and Davis, 1969). The mechanism of compaction due to oil or gas extraction is similar to that of groundwater withdrawal. Fracture and pore space are compressed as the effective stresses on the soil/rock skeleton are increased due to fluid pressure decline. At Wilmington, subsidence is now being controlled by maintaining the fluid pressure by water injection.

The subsiding area tends to form a bowl-shaped depression which extends slightly beyond the production area. Nine meters of subsidence were recorded at Wilmington (Yerkes and Castle, 1969) and a maximum rate of $0.71 \mathrm{~m} /$ year was recorded (Mayuga and Allen, 1969). Tension cracks were observed at the outer edges of the subsidence bowl in the Goose Creek field (Poland and Davis, 1969). The areas affected by 011 and gas subsidence vary in size: $65 \mathrm{~km}^{2}$ at Wilmington, $11 \mathrm{~km}^{2}$ at Goose Creek, and about $400 \mathrm{~km}^{2}$ in the Po Delta (Atherton et al, 1976).

Substantial horizontal movements have been observed to accompany oil field subsidence, e.g., nearly $3 \mathrm{~m}$ at Wilmington (Mayuga and Allen, 1969). Surface faulting has been observed at Goose Creek, Inglewood, Kern Front, and Mykawa field (in California and Texas), with associated differential subsidence of as much as $2.3 \mathrm{~m}$, horizontal displacement of $0.4 \mathrm{~m}$ and active movement continuing during production (Yerkes and Castle, 1969). Table A-2 presents selected data on $0 i 1$ and gas subsidence areas. 
TABLE A-2 - SELECTED DATA FROM OIL AND GAS SUBSIDENCE AREAS (from Atherton et a1, 1976)

。

\begin{tabular}{|c|c|c|c|c|c|c|c|c|}
\hline & $\begin{array}{l}\text { WILMIMGION } \\
\text { CALIFORNIA }\end{array}$ & $\begin{array}{l}\text { LONG BEACH } \\
\text { CALIFORNIA } \\
\end{array}$ & $\begin{array}{l}\text { INGLENOOO } \\
\text { CAL IFORNIA }\end{array}$ & $\begin{array}{l}\text { HUNTINGTON BEACH } \\
\text { CALIFORNIA }\end{array}$ & $\begin{array}{l}\text { COOSE CREER } \\
\text { TEXYS }\end{array}$ & $\begin{array}{l}\text { LAKE MARACA1BO } \\
\text { VENEZUELA }\end{array}$ & $\begin{array}{l}\text { PO DELTA } \\
\text { ITALY }\end{array}$ & $\begin{array}{l}\text { MIIGATA } \\
\text { JAPAN }\end{array}$ \\
\hline \multicolumn{9}{|l|}{ SURFACE DEFORMATION } \\
\hline \multicolumn{9}{|l|}{ Subs idence } \\
\hline Ared Affected & $.65 \mathrm{~km}^{2}(1970)$ & $31 \mathrm{~km}^{2}$ & $11 \mathrm{~km}^{2}$ & $37 \mathrm{~km}^{2}$ & $10 \mathrm{~km}^{2}$ & $400-700 \mathrm{~km}^{2}$ & $.400 \mathrm{~km}^{2}$ & $>800 \mathrm{~km}^{2}$ \\
\hline Maximum Subsidence & 8. $\sin (1928-1970)$ & $0.75 \mathrm{~m}(1925-1967)$ & $1.73 m(1911-1963)$ & $1.22 \mathrm{~m}(1933-1965)$ & $\ln (1918-1925)$ & $0.3-3.3 m(1926-1954$ & 54) & $0.8 m(1900-1960)$ \\
\hline Substdence Rate & $\begin{array}{l}33-77 \mathrm{~cm} / \mathrm{yr} \\
\text { (1947-1958; } \\
\text { before injection) }\end{array}$ & $\begin{array}{l}\text { avg. } 1.8 \mathrm{~cm} / \mathrm{s} r \\
(1925-196)\}\end{array}$ & $\begin{array}{l}\operatorname{avg} . \\
(1911-1963)\end{array}$ & avg. ${ }^{3} \cdot 8 \mathrm{~cm} / \mathrm{yr}$ & $\begin{array}{l}\text { avg. } 14 \mathrm{~cm} / \mathrm{yr} \\
(1918-1923)\end{array}$ & $30 \mathrm{~cm} / \mathrm{yr}\left(1930^{\circ} \mathrm{s}\right)$ & $\begin{array}{l}1-3 \mathrm{~cm} / \mathrm{yr}(1 \mathrm{g90}-195 \mathrm{u}) \\
\max 30 \mathrm{~cm} / \mathrm{yr}\end{array}$ & $40-50 \mathrm{~cm} / \mathrm{yr}$ \\
\hline \multicolumn{9}{|l|}{ Horizontsi Movement } \\
\hline Maximum Movenent & $3.7 m(1937.1970)$ & • & $0.76 \mathrm{~m}(1934-1963)$ & - & • & • & * & $*$ \\
\hline Rate & $11 \mathrm{~cm} / \mathrm{yr}(1937-1970)$ & & $\begin{array}{l}\text { svg. } 2.6 \mathrm{~cm} / \mathrm{yr} \\
(1934-1963)\end{array}$ & & & & & \\
\hline \multicolumn{9}{|l|}{ Associated Faulting } \\
\hline Type & Low angle & None & High angle, normal & None & High angle, normal & None & None & None \\
\hline Location & Central & & Perloheral & & Peripheral & & & \\
\hline Earthquake & $.6(1947-7961)$ & & & & & & & \\
\hline Magnit tude & $2.4-3.3$ & & & & & & & \\
\hline $\begin{array}{l}\text { Time of Principal } \\
\text { Oecurrence }\end{array}$ & $\begin{array}{l}1947-1958+\text { (now } \\
\text { hal ted by injection) }\end{array}$ & $1925-1967$ & $1911-1963$ & $1933-1965$ & $1917-1926$ & $1926+1954$ & $1950-1960$ & $1955-1960+$ \\
\hline \multicolumn{9}{|l|}{ RESERVOIR MATERIALS } \\
\hline $\begin{array}{l}\text { Type, Age, } \\
\text { Consolidation }\end{array}$ & $\begin{array}{l}\text { Unconsolidated to } \\
\text { semiconsolidated } \\
\text { sand with inter- } \\
\text { bedded clay and } \\
\text { shale (marine). } \\
\text { tiocene to } \\
\text { pl tocene Age }\end{array}$ & $\begin{array}{l}\text { Similar to } \\
\text { Wiimington }\end{array}$ & $\begin{array}{l}\text { Similar to } \\
\text { Wllmington }\end{array}$ & $\begin{array}{l}\text { Similar to } \\
\text { vilmington }\end{array}$ & $\begin{array}{l}\text { Unconsolidated sand } \\
\text { and clay of } \\
\text { oligocene to } \\
\text { Plfacene age }\end{array}$ & $\begin{array}{l}\text { Interbedded sand, } \\
\text { clay and stit } \\
\text { of Miocene age }\end{array}$ & $\begin{array}{l}\text { Unconsolidated } \\
\text { calcareous sands } \\
\text { with fnterbedded } \\
\text { clay (littoral } \\
\text { and lagoonal) } \\
\text { Quaternery age }\end{array}$ & $\begin{array}{l}\text { Decansolidated } \\
\text { sand, sandstone } \\
\text { and conglomerate } \\
\text { with interbedded } \\
\text { clay. Cenozoic age }\end{array}$ \\
\hline Porosity & $20-352$ & & & & & & & \\
\hline Permeability & $100-1500 \mathrm{mb}$ & & & & & & & \\
\hline Compaction Behavior & $\begin{array}{l}\text { 60\% of compaction } \\
\text { in sands, o0\% in } \\
\text { cloys and shales }\end{array}$ & & & & & $\begin{array}{l}\text { Compaction } \\
\text { roughly equal } \\
\text { in sands and } \\
\text { clays }\end{array}$ & & $\begin{array}{l}\text { Cause of some } \\
\text { subs Idence pritor } \\
\text { to development } \\
\text { is unknown }\end{array}$ \\
\hline \multicolumn{9}{|l|}{ OVEREURDEN } \\
\hline $\begin{array}{l}\text { Type, Competence } \\
\text { Deforma tion Properties }\end{array}$ & $\begin{array}{l}\text { Unconsol idated } \\
\text { shale, sand, } \\
\text { clays tone, and } \\
\text { silts tone of } \\
\text { pliocene and } \\
\text { Pleis tocene age }\end{array}$ & $\begin{array}{l}\text { Similar to } \\
\text { Wilmington }\end{array}$ & $\begin{array}{l}\text { Similar to } \\
\text { Wilmington }\end{array}$ & $\begin{array}{l}\text { Similar to } \\
\text { Wilmington }\end{array}$ & $\begin{array}{l}\text { Similar to } \\
\text { reservoir rock }\end{array}$ & & $\begin{array}{l}\text { Similar to } \\
\text { reservotr rock? }\end{array}$ & $\begin{array}{l}\text { Similar to } \\
\text { reservoir rock? }\end{array}$ \\
\hline \multicolumn{9}{|l|}{ REGIONAL GEOLOGIC STRUCTURE } \\
\hline $\begin{array}{l}\text { Folding, Faulting, } \\
\text { Regional Stress }\end{array}$ & $\begin{array}{l}\text { Broad anticline, } \\
\text { flank dips } 20-60^{\circ} \text {. } \\
\text { with numerous } \\
\text { transverse nomal } \\
\text { faults indicating } \\
\text { tensile stress }\end{array}$ & $\begin{array}{l}\text { Tightly folded } \\
\text { anticline, high- } \\
\text { angle reverse } \\
\text { falting } \\
\text { indicating } \\
\text { compressive stress }\end{array}$ & $\begin{array}{l}\text { Anticline; } \\
\text { faulting? }\end{array}$ & $\begin{array}{l}\text { Anticline } \\
\text { faulting? }\end{array}$ & $\begin{array}{l}\text { Gentle done in } \\
\text { Miocene and } \\
\text { younger sediments: } \\
\text { older deposits } \\
\text { intensely faulted }\end{array}$ & & Gently folded & \\
\hline \multicolumn{9}{|l|}{ PRODUCTION } \\
\hline Depth & $\begin{array}{l}600-2300 m \\
\text { (most } 600-1100 m)\end{array}$ & median $1690 \mathrm{~cm}$ & median $900 m$ & medion $930 \mathrm{~m}$ & $200-1400 m$ & & I(one wel1 $700 \mathrm{~m}$ ) & $1-1000 m$ \\
\hline Fluid Type & $\begin{array}{l}\text { oli, water, and } \\
\text { gas }\end{array}$ & ofl and water & $\begin{array}{l}\text { of 1: water and } \\
\text { gas? }\end{array}$ & $\begin{array}{l}\text { oil i water and } \\
\text { gas? }\end{array}$ & $\begin{array}{l}\text { oil, gas, and } \\
\text { water }\end{array}$ & oil and water (?) b & $\begin{array}{l}\text { brine with dissolved } \\
\text { methane }\end{array}$ & $\begin{array}{l}\text { brine with dissolved } \\
\text { methane }\end{array}$ \\
\hline Production Rate & O11: $11-22 \times 10^{3} \mathrm{~m}^{3} / d a y$ & & & & $\begin{array}{l}\text { avg. totel: } \\
1.8 \times 10^{6} \mathrm{~m}\end{array}$ & & $\frac{9 a s(1956) \dot{m}}{3550 \times 10^{3} m^{3} / \text { day }}$ & $\begin{array}{l}\text { gas }(1963): \\
575 \times 10^{3} \mathrm{~m} 3 / \text { day }\end{array}$ \\
\hline \multirow[t]{3}{*}{ Total Production } & $.011+$ water: & & & & $\begin{array}{l}\text { o11(plus water? } \\
1917-1926): \\
>16 \times 10^{6} \mathrm{~m}\end{array}$ & & $\begin{array}{l}\text { Total(1956), if } \\
\text { wateragas: } \\
1.7 \times 10^{6}: m^{3} \text { day }\end{array}$ & $\begin{array}{l}\text { Total (1956), if } \\
\text { waterogas } \\
1.2 \times 106 \mathrm{~m} / \text { day }\end{array}$ \\
\hline & gos: $24 \times 10^{9} \pi^{3}$ & & - & & & & & \\
\hline & total: $24 \times 10^{9} \mathrm{~m}^{3}$ & & . & & & & & \\
\hline Maximum Pressure Decline & $\sim 77 \mathrm{~kg} / \mathrm{cm}^{2}(1100 \mathrm{ps} 1)$ & & & & $\begin{array}{l}70-84 \mathrm{~kg} / \mathrm{cm}^{2} \\
(1000-1200 \mathrm{psi}) \\
(1917-1926)\end{array}$ & $\sim 70 \mathrm{~kg} / \mathrm{cm}^{2}(1000 \mathrm{psi})$ & $?\left(\begin{array}{l}\left.15 \mathrm{~kg} / \mathrm{cm}^{2} 210 \mathrm{ps} f\right) \\
(1960)\end{array}\right.$ & \\
\hline Subs Idence: Head Dectine & $\sim .01$ & & & & $\sim .001$ & & $\sim .005$ & \\
\hline Production from Compaction & $\begin{array}{c}\text { ng:(1928-1962, } \\
\text { tgnoring gas) }\end{array}$ & & $\cdot$ & & $20 \div(1917-1926)$ & & & \\
\hline
\end{tabular}

Notes:

1) Dates in parentheses indicate period of measurement or year of report

2) Densities used for conversions, at $250^{\circ} \mathrm{C}$ and 1 atm:natural $9 \mathrm{as}, 0.829 \mathrm{~kg} / \mathrm{m}^{3}$ :

of $1,858 \mathrm{~kg} / \mathrm{m}^{3}$; water, $1000 \mathrm{~kg} / \mathrm{m}^{3}$

- Not measured

Sources: Van der knaap and Van der VIis, 1967; Poland and Davis, 1969; 


\section{A. 3 TECTONISM}

Subsidence due to tectonism is a gradual or sudden movement in the earth's crust. Sources of tectonic movements typically occur at depths greater than that of other sources of subsidence discussed in this paper. The "Palmdale Bulge" in southern California is a well-documented example of gradual uplift, with roughly $0.28 \mathrm{~m}$ of uplift occurring between 1961 and 1971 (Real and Bennett, 1976). Typical rates of tectonic subsidence and uplift in the United States are 0.001 to $0.015 \mathrm{~m}$ per year (Press and Siever, 1974), and involve broad areas as shown in Figure A-3.

Rapid tectonic uplift or subsidence may accompany earthquakes. For example, the San Fernando, California earthquake of 1971 caused roughly $1 \mathrm{~m}$ of vertical movement and $1.5 \mathrm{~m}$ of horizontal movement (Green, 1973). As a result of the Alaskan earthquake of 1964, a maximum uplift of $13 \mathrm{~m}$ and maximum subsidence of $2 \mathrm{~m}$ occurred at different locations in an interval of a few minutes (Press and Siever, 1974).

Because geothermal areas are associated with magmatism high in the earth's crust and are often near plate boundaries (White, 1973), tectonic forces can be an important source of movement. In addition, there is some evidence to suggest that fluid extraction may induce faulting (Holzer, 1976). Extensive removal of fluids from a large area may cause heave of the crust.

\section{A. 4 COLLAPSING SOILS (HYDROCOMPACTION)}

Some soils collapse when wetted. These soils are typically silty sands to clays and are of high porosity, e.g., 43 to $85 \%$ in the San Joaquin Valley (Curtin, 1973). Vertical movements of up to $4 \mathrm{~m}$ have been recorded as a result of hydrocompaction (Curtin, 1973). Subsidence may extend a hundred meters or more outside the wetted zone. The edges of the depression can be steep scarps at the angle of repose of the material. The boundary of the wetted zone is often scarred with concentric cracks (Riley, 1970). 


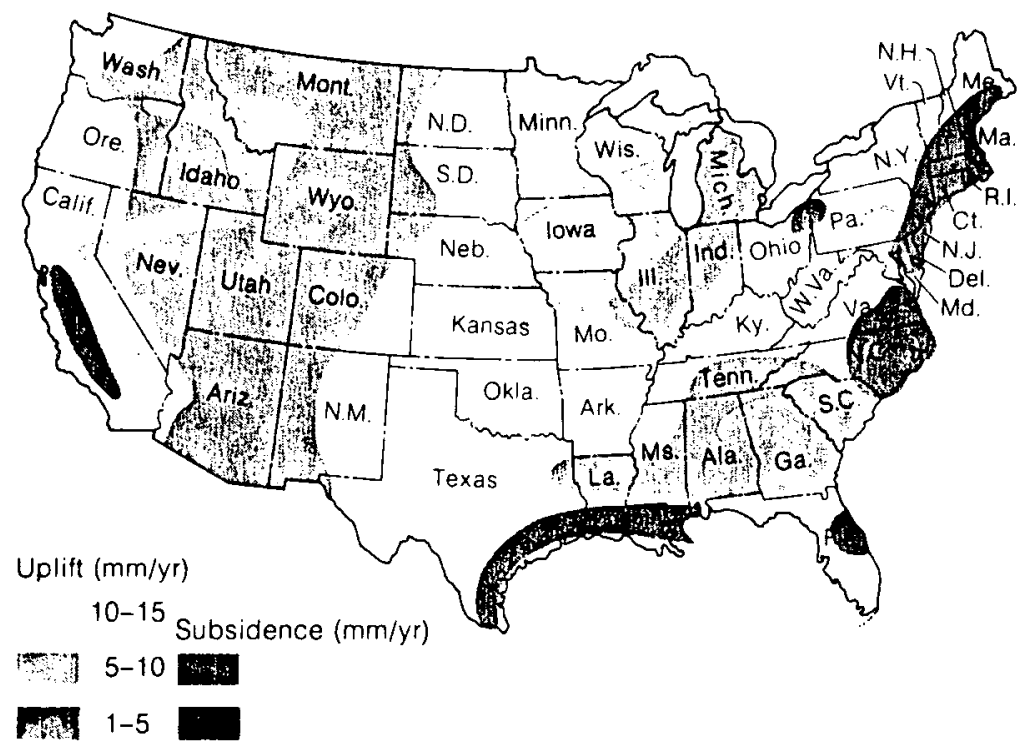

(Press and Siever, 1974)

FIGURE A-3 - CRUSTAL-MOVEMENT MAP SHOWING AREAS OF PRESENT-DAY UPLIFT AND SUBSIDENCE IN THE UNITED STATES 
Hydrocompaction is characterized by relatively rapid dramatic movement (Curtin, 1973) as also illustrated in Figure A-4. Hydrocompaction in infiltration ponds and test plots along the alignment of the California aquaduct amounted to 0.6 to $2.1 \mathrm{~m}$ (Lucas and James, 1976) and occurred rapidly. In a test plot, hydrocompaction was completed in 3 years. By intensive use of infiltration wells, it was completed in 6 months along the canal alignment (Lucas and James, 1976).

\section{A.5 SOIL OXIDATION}

Peat and organic soils, when drained and exposed to air after being submerged, tend to oxidize and lose volume. Biochemical oxidation has been responsible for 55 to $75 \%$ of the subsidence of the Everglades, Florida organic soil. Subsidence there averages $32 \mathrm{~mm}$ per year (Stephens and Stewart, 1976). Lower rates of subsidence due to oxidation occur in colder climates.

\section{A.6 UNDERGROUND MINING}

Subsidence due to underground mining has been extensively documented in Europe and to some extent in the United States. (See Figure A-5 for definitions of typical mining subsidence terminology.) When mining a relatively horizontal seam, a trough-like depression typically develops above the mine as a result of the overburden bending and collapsing into the mined-out void. Over coal mines, subsidence may vary from 0 to $90 \%$ of the extracted thickness (Warde11, 1970), depending on the amount and type of support provided at mine level and on the competency of the overburden. In the United States, maximum subsidence over a single coal seam usually does not exceed $1.2 \mathrm{~m}$ (Woodward-Clyde Consultants, 1.977a). However, over a large block caving operation for mining copper, a hundred meters of subsidence may occur (Johnson and Soule, 1963).

Significant horizontal movements may accompany underground mining. As much as $0.2 \mathrm{~m}$ of displacement has been observed over U. S. coal mines (Woodward-Clyde Consultants, 1977a), and cracks have been observed to open as much as 0.4 to $0.6 \mathrm{~m}$ (Dunrud, 1976). Horizontal movements appear 




(Lucas and James, 1976)

FIGURE A-4 - TYPICAL HYDROCOMPACTION SUBSIDENCE - TIME RELATIONSHIP 


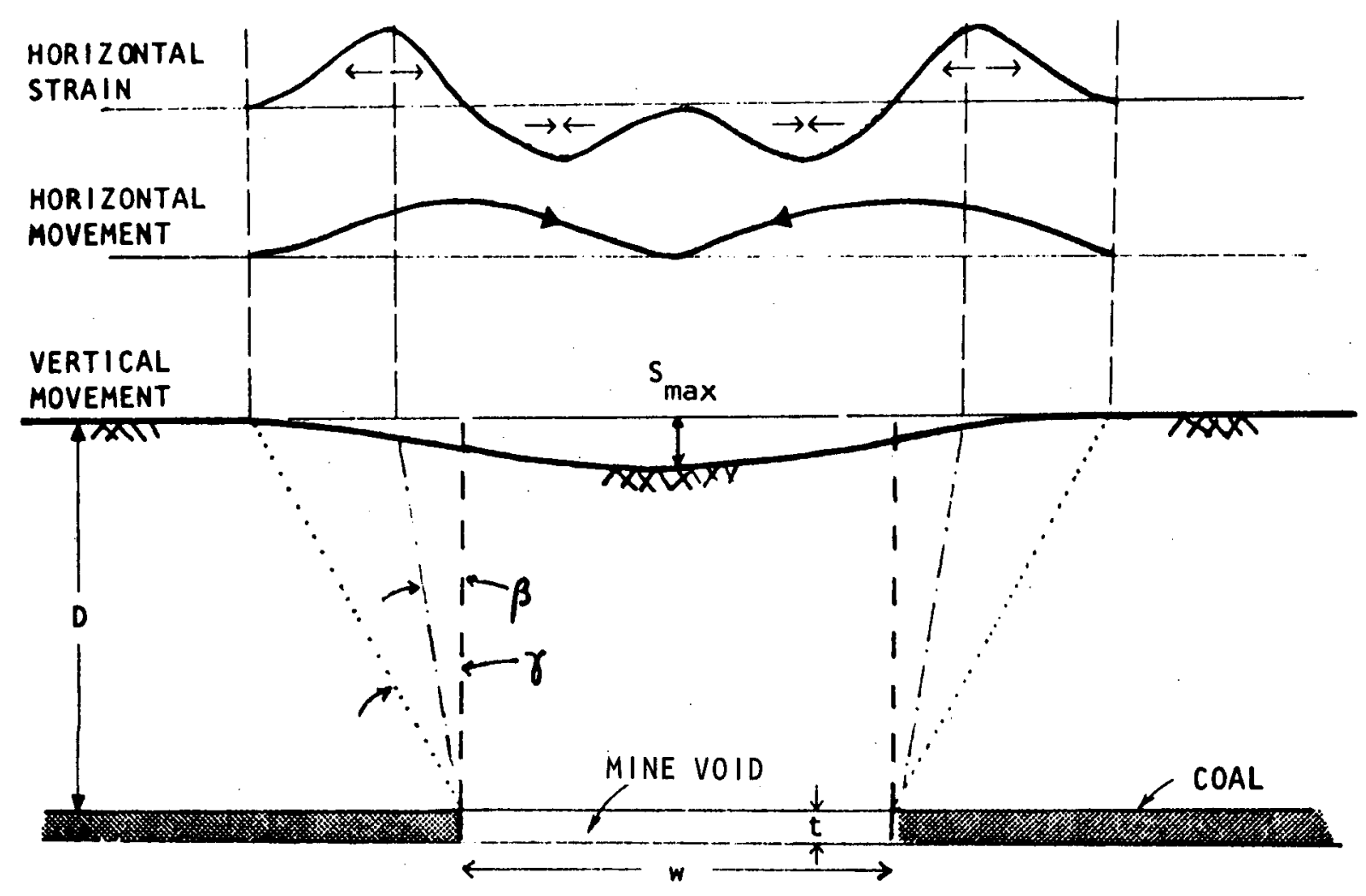

KE Y :

$$
\begin{aligned}
& S_{\max }: \begin{array}{l}
\text { Maximum possible vertical } \\
\text { subsidence given thickness } \\
\text { of extracted seam }
\end{array} \\
& t: \text { Thickness of extracted seam } \\
& D: \text { Depth to coal seam from surface } \\
& w: \text { Width of mine void } \\
& \gamma: \text { Angle of draw } \\
& \beta: \text { Angle of break }
\end{aligned}
$$

FIGURE A-5 - TWO DIMENSIONAL MODEL OF SUBSIDENCE (Shown for Mine Void of Critical Width) 
to result from the bending action of the overburden and into the minedout void. Cracks tend to open in the zone of maximum tension and buckling may occur where high compressive stresses are developed.

Subsidence movements tend to be rapid over a seam where the extraction ratio (percent of mineral removed) is high and the extraction is at least of critical width. In England most of the subsidence occurs within a few months of mining, and movement is essentially complete after two or three years (Warde11, 1970). Where support that may deteriorate with time is provided at the mine level, subsidence may take hundreds of years to develop.

The extent of mining subsidence beyond the edge of the mine is controlled by the angle of draw, and is approximately equal to the depth to the mined seam. In an extensively developed mining district with many mines, subsidence can affect tens to hundreds of square kilometers. The angle of draw (usually 30 to 60 degrees) seems to be relatively constant in a mining district and is controlled by the competency of the overburden in relation to a given mining technique.

While mining subsidence is not likely to occur in a geothermal areas, the well-developed terminology and understanding of mining subsidence mechanisms may be useful in the evaluation of geothermal subsidence.

\section{A.7 LANDSLIDES}

This phenomenon is not strictly a subsidence process. However, in at least one major geothermal area, the Geysers, it is an important source of ground movement. In fact $50 \%$ of the wells at the Geysers are sited on Quaternary landslides (Bacon, 1976), and the presence of a high water table in the area tends to encourage the development of new slides and the reactivation of old ones. In March of 1975, a reactivated landslide caused the blowout of a well at the Geysers; the slide was estimated to be $38 \mathrm{~m}$ deep (Bacon, 1976). 
Classical landslides are generally characterized by an uphill scarp and an uplifted zone at the toe, and are often marked by tilted trees, giving evidence of recent rotational or sliding movement. Geologic inspection of a geothermal area, including study of aerial photography, should reveal the potential for landslides and evidence of previous landslides.

The rate of landslide movement is variable. Slow, barely-perceptible slope creep may occur for years. Rapid movement may occur over a matter of minutes or days. Frequently a high groundwater table or substantial rainfall is associated with landsliding; therefore, a common preventive or remedial measure is to install drains. 
Some "developers contend that subsidence should be less in geothermal than in groundwater and hydrocarbon areas because the geothermal reservoir and overburden usually consist of rock types more resistant to deformation" (Woodward-Clyde Consultants, 1977b). Productive geothermal fields exist in several countries and appreciable subsidence has been measured at a number of them. The magnitude and extent of geothermal subsidence depend on the characteristics of the overburden and reservoir, and the production conditions. Table B- 1 summarizes the factors that contribute to subsidence and the factors that favor stability.

\section{B. 1 CAUSES OF GEOTHERMAL SUBSIDENCE}

This section and section B.2 discuss the principal mechanism involved and the potential for subsidence in relation to the type of geothermal reservoir being exploited. The text has been extracted from Interim Report No. 1, Geothermal Subsidence Research Category 3, Project 1, prepared by Woodward-Clyde Consu1tants, December 1977.

By analogy with hydrocarbon and groundwater subsidence areas, the major process which may cause 1 and subsidence in geothermal areas is considered to be loss of pore space due to fluid withdrawal (Atherton et al, 1976; Finnemore and Gillam, 1976). This process may affect both intergranular (primary) pore space and fracture (secondary) space. A smaller amount of reversible subsidence may result from thermal contraction associated with reservoir cooling.

\section{B.1.1 Fluid Withdrawal}

"Compaction results from a transfer of load from the pore fluid of a rock (or soil) to its solid grain framework. This transfer takes place as the pore fluid is sucked or squeezed from the rock, causing the internal pore fluid pressure to decrease. The additional load applied to the grains tends to rearrange, distort, and break them causing the rock to reduce in volume" (Atherton et al, 1976). 


\section{TABLE B- 1 - FACTORS TENDING TO INFLUENCE GEOTHERMAL SUBSIDENCE \\ (Atherton et al, 1976)}

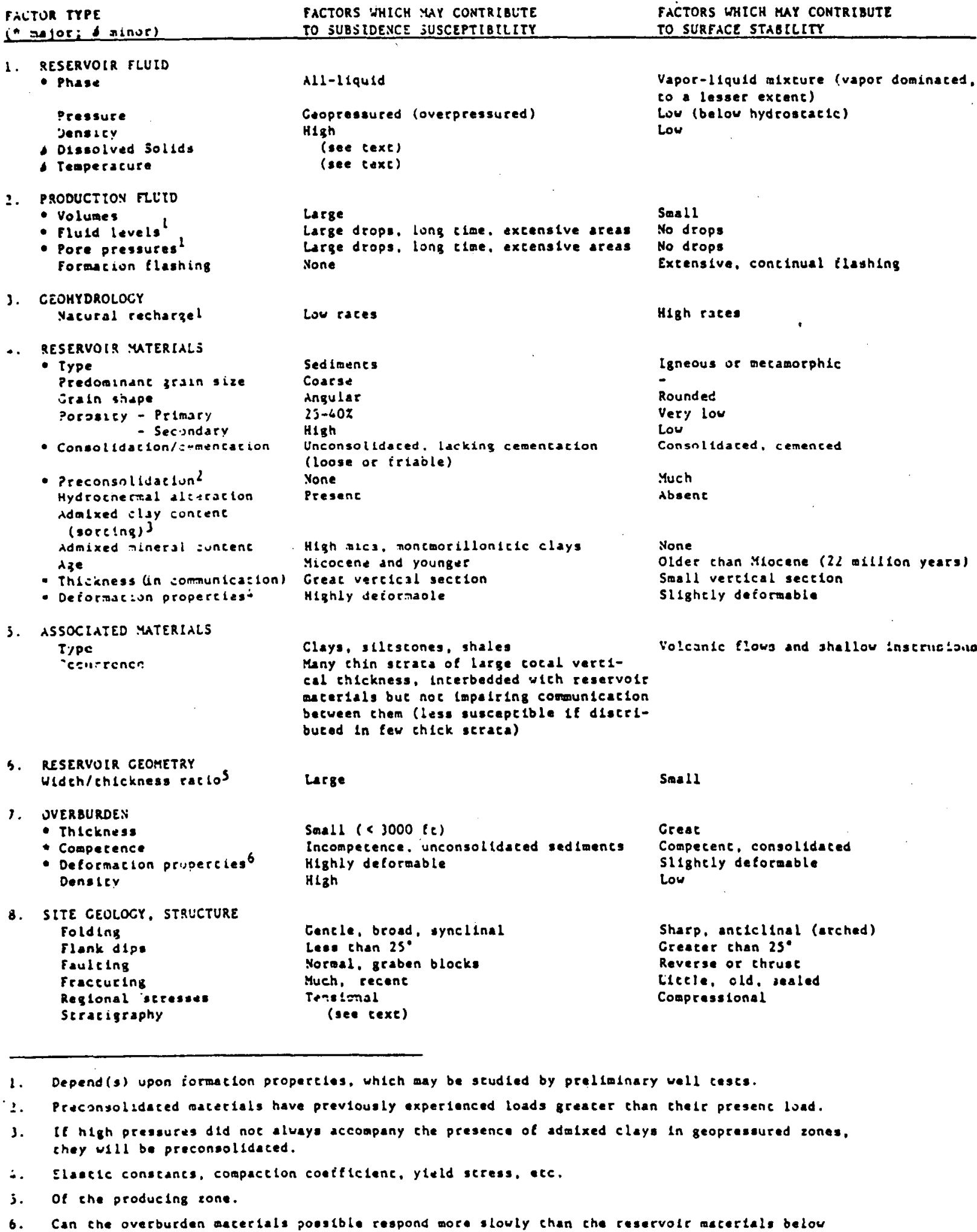

All-liquid

Goopressured (overpressured)

High

(see cexe)

(see texc)

- Olssolved sollds

- Temperacure

?. PRODUCTTON RLTD

- Volumes

- Elula levelol

- Pore pressures'

Formacion tlashing

Large

Large drops. Lung slase. excensive areas

Large drops, long idme, extensive areas None

No drops

No drops

Extensive, continual tashing

Lou races

Sedimenes

Coarse

Angular

$25-60 z$

High

Unconsolldaced. Lackins cemencacton

(loose or iriable)

Yone

Pregene

Hydroznertial altaraction

ddalxed ilsy concene

(sore!ng)

Admixed minersi suncent

Aze

- Thlikness (in somunicazion)

- Deciormacion propercies:

High alcs, nonemorillanicle clays

Yicocene and younges

Great vercical section

Mlzhly deciorinaole

3. ASSOCIATED MATERIALS

T/pe

esir-rener.

Clays, silestones, shales

Many thin strata of large cocal verti-

cal chlckness, Incerbedded wich reservolt aterials but not impalring comonication between them (bess susceptible if distributed In few chick scraca)

b. RESERVUIR CEOMETRY

Width/ehlckness raclos

Lerge

Sma11

1. JVERBURDEN

- Intekness

- Comperence

- Deformacion peipercies 6 Densiser

Srall ( $<3000 \mathrm{fe}$ )

Incompecence. unconsolidaced sed lments

Highly deformable

HLah

Grear

Compecent, consolidaced

Sightly deformable

Low

8. SITE CEOLOCY, STRUCTURE

Fold lng

rlenk dipe

rauleing

Freceuring

Reglonal screseds

Stracigraphy

Cencle, beoad, synclinal

Lees than $25^{\circ}$

Norwal, graben blocks

Much, recent

Ters!mal

(see text)

FACTORS WHICH MAY CONTRIBUTR

Vapor-1lquid alxcure (vapor dominaced, - lesser extent)

hu (belou hydroseacic)

High races

Igneous or Decamorphlc

Rounded

Very low

Lou

Consolidaced, cemenced

Much

Absent

None

Older chan Miocene ( $2 L$ willion years)

Small vericical section

slighely deciormable

Volesnte flows and shallow instructonto

Sharp, anciclinal (arched)

Greacer chan $25^{\circ}$

Reversa or chruat

Clecle, old, sasled

Compressional

1. Depend(s) upon iormation propertles, which may be seudled by prellminary well teses.

2. Preconsolidaced racerials have previously experienced loads greacer chan thele presenc luad.

3. If high pressures did not luays accompany the presence of adrixed clays in geopraseured zones, chey will be preconsolidated.

- Slaecle conscancs, compaction coetfletenc, yteld scress, ece.

j. Of the producing zone.

6. Can the overburden acterlals possble respond more slowly chan che reservolt matertals belou 
The principles causing this type of compaction, and associated horizontal movements, have been stated in terms of seepage stresses resulting from the viscous drag of moving water on rock grains (Lofgren, 1968); however, the concept of effective stress (Terzaghi and Peck, 1967) applicable to vertical stresses and movements, is more easily related to fluid pressure. This theory states that the effective downward stress carried by the rock or soil structure equals the geostatic pressure (due to the combined weight of overlying rock and interstitial water) minus the fluid pressure. Thus, a decrease in fluid pressure caused by pumping results in an increased effective stress and leads to compaction.

Compaction of intergranular pore space is considered the most important process causing subsidence in geothermal areas, but experiments on core samples show that increased effective stress may also reduce the volume of fracture pore space (Batzle and Simmons, 1976). Using this data, Atherton et al (1976) predict a maximum compaction of $5 \mathrm{~cm}$ due to microfracture closing in a reservoir $1.5 \mathrm{~km}$ thick which experiences a uniform change in fluid pressure of $100 \mathrm{~kg} / \mathrm{cm}^{2}$. A lesser vertical strain is likely in most geothermal areas.

\section{B.1.2 Thermal Contraction}

"The contribution of thermal contraction to total subsidence at geothermal areas will probably be minor because of the small value of thermal expansion coefficients (typically one part in $10^{5}$ or $10^{6}$ per ${ }^{0} \mathrm{C}$ ) and small changes in average temperature which result from production... . Order of magnitude calculations . . . indicate that uniformly cooling a geothermal reservoir $1 \mathrm{~km}$ thick by $20^{\circ} \mathrm{C}$ could produce $20 \mathrm{~cm}$ of shortening" (Finnemore and Gillam, 1976). Cooling may be more extreme near injection wells, but such wide-spread cooling is unlikely.

\section{B.1.3 Earthquake Shaking}

"Earthquake shaking can contribute to the compaction of porous, unconsolidated materials by facilitating grain rearrangement. For example, at Wilmington oil field in California, the rate of ground subsidence increased temporarily by several centimeters per year (Poland and Davis, 1969) in 
response to two moderate-sized earthquakes . . Since most geothermal areas are located near the boundaries of major crustal plates, . . geothermal areas as a group are more likely to experience seismic shaking than other fluid resource areas" (Atherton et a1, 1976).

\section{B.2 SUBSIDENCE POTENTIAL OF GEOTHERMAL FIELDS}

Geothermal fields have been divided into several types on the basis of the mode of heat transfer and the presence and state of water (White, 1973; White and Williams, 1975). The risk of subsidence varies at these different types of fields, primarily depending on their susceptibility to large changes in fluid pressure and thus to loss of pore space. Two types of geothermal resources, magma and hot rock, are not discussed because they contain no natural water and cannot be developed economically under current or near-current technology. The subsidence potential of various types of geothermal fields has been recently reviewed by Atherton et al (1976) and Finnemore and Gillam (1976); their assessments are summarized in Table B-2.

Researchers in subsidence and geothermics appear to have reached a general consensus on the potential for fluid-withdrawal subsidence in geothermal areas. The following summary is quoted from Atherton et al (1976).

- Vapor-dominated systems - Fluid withdrawal is expected to cause at most a few centimeters of subsidence in these areas because of the vapor phase of the geothermal fluids and the induration of the reservoir rock (White, 1973; Lofgren, 1973; Sanyal, oral communication, 1976).

- Liquid-dominated systems (normally pressured) - Subsidence is considered a definite hazard in these areas unless injection is practiced to prevent widespread reductions in fluid pressure. White (1973) considers subsidence particularly likely where the reservoirs consist in part of clay, silt, or shale which may dewater into the coarse-grained beds. Lofgren (1973) states that subsidence in the Imperial Valley is a definite hazard unless precautions are taken. 
TABLE B-2 - ESTIMATED RANGES OF EXPECTED SUBSIDENCE IN GEOTHERMAL AREAS

(after Atherton et al, 1976)

\begin{tabular}{|c|c|c|c|c|c|c|c|}
\hline $\begin{array}{c}\text { Resource } \\
\text { Type }\end{array}$ & $\begin{array}{c}\Delta \mathrm{P}^{\star} \\
\left(\mathrm{kg} / \mathrm{cm}^{2}\right)\end{array}$ & $\begin{array}{l}\Delta \mathrm{T} \\
\left({ }^{\circ} \mathrm{C}\right)\end{array}$ & $\begin{array}{c}\text { Fluid } \\
\text { Withdrawal }\end{array}$ & $\begin{array}{l}\text { Fracture } \\
\text { Closing }\end{array}$ & $\begin{array}{c}\text { Earthquake } \\
\text { Shaking }\end{array}$ & $\begin{array}{c}\text { Thermal } \\
\text { Contraction }\end{array}$ & $\begin{array}{l}\text { Tectonic } \\
\text { Movements }\end{array}$ \\
\hline Magma & --- & $\leq 300$ & $-\cdots$ & --- & --- & $x$ & Variable \\
\hline Hot Rock & --- & $\leq 200$ & --- & --- & $-\cdots$ & $x$ & Variable \\
\hline Steam & 30 & -5 & $x$ & $x$ & $x$ & $x$ & Variable \\
\hline Hot Water & $50-250$ & $10-50$ & $x x$ or $X X X$ & $x$ or $x x$ & $x$ or $x x$ & $x$ & Variable \\
\hline Geopressured & $250-400$ & $10-50$ & $x x x$ & $x$ & $x$ & $x$ & Variable \\
\hline
\end{tabular}

Key to estimated range:

$$
\begin{gathered}
x X X \text { - more than } 1 \mathrm{~m} \\
X X \text { - less than } 1 \mathrm{~m} \\
X \text { - few mm or } \mathrm{cm} \\
\text {-.- - not applicable }
\end{gathered}
$$

*Approximate maximum drawdown to minimum enthalpy input requirements of generating systems; depends on both temperature and pressure. Full flashing assumed in initially liquid reservoirs. 
- Geopressured - Subsidence over geopressured resources is considered likely (Whiting, 1973; White, oral communication, January 1976; Kreitler, oral communication, June 1976). The reservoir sands in these areas are well cemented (Kreitler, oral communication, June 1976), but significant drainage is expected from undercompacted shales (Papadopulos et al, 1975). Whiting (1973) has stated that, in the geopressured reservoirs, an economic abandonment pressure would be reached before the pressure decline was sufficient to cause subsidence, implying that a threshold pressure must be surpassed. However, because the geopressured sediments have never borne the ful1 weight of the overburden, Kreitler challenges Whiting's statement. Two studies of potential production practices have suggested disposing of waste water from geopressured reservoirs by pumping into shallow, normally pressured aquifers (Wilson et a1, 1974; House et a1, 1975), despite the fact that this procedure would not tend to mitigate subsidence. Production scenarios developed by Kreitler and Papadopulos et al (1975) predict subsidence. The latter scenario forecasts $5-7 \mathrm{~m}$ of subsidence, assuming that an initial hydrostatic head of 450 $580 \mathrm{~kg} / \mathrm{cm}^{2}$ is reduced to $140 \mathrm{~kg} / \mathrm{cm}^{2}$. Subsidence predictions such as the preceding one are considered highly tentative. The general consensus among researchers is that actual experience will be required to determine how geothermal systems respond to changes in effective stress, and that monitoring will have to continue for several years before firm conclusions can be reached.

\section{B.3 GROUND MOVEMENTS ASSOCIATED WITH GEOTHERMAL SUBSIDENCE}

In subsiding areas, three major types of ground movements may occur vertical, horizontal, and faulting. Vertical movement reflects some percentage of the reservoir compaction. Horizontal movement is associated with the induced strains as the "subsidence bowl" is formed and with the horizontal fluid pressure gradients induced by production. The faulting associated with subsidence may occur around the periphery of the "subsidence bow1" or in the center of the subsidence area. The 
peripheral faults are usually high angled and normal to the central area of subsidence, while the centrally located faults are usually lowangled and reverse (Atherton et al, 1976).

\section{B.4 MAGNITUDES OF SUBSIDENCE}

The geothermal field at Wairakei, New Zealand, subsided $4.7 \mathrm{~m}$ from 1956 to 1974, and the associated horizontal movements totaled $0.8 \mathrm{~m}$ as of early 1975 (Stilwell and others, 1975). These are the largest movements recorded at a geothermal field. Two additional fields in New Zealand, the Broadlands and Kawerau, have experienced subsidence, but not to the extent of the Wairakei field.

At the Broadlands subsidence totaled $0.18 \mathrm{~m}$ and the horizontal movement $0.12 \mathrm{~m}$ between 1969 and 1975. The subsidence at Kawerau is less, with a measured vertical movement of $0.028 \mathrm{~m}$ in one year. Horizontal movements were not measured (Stilwell and others, 1975). Table B-3 summarizes the information from the three New Zealand geothermal fields.

The only productive geothermal field in the United States is the Geysers field in California. It is a vapor-dominated field with a reservoir consisting of well-cemented sandstone (Woodward-Clyde Consultants, 1977b). A few centimeters of induced subsidence has occurred from 1972 to 1974 (Lofgren, oral communication, 1976).

\section{B.5 AREAL EXTENT OF GEOTHERMAL SUBSIDENCE}

The small areal extent of most geothermal reservoirs (typicaliy less than $100 \mathrm{~km}^{2}$ ), and the relative impermeability of faulted or hydrothermally cemented reservoir boundaries may restrict subsidence to a small area (Finnemore and Gillam, 1976). Subsidence at Wairakei covers $65 \mathrm{~km}^{2}$, and at the Broadlands geothermal field $73 \mathrm{~km}^{2}$. The Geysers subsidence area covers approximately $42 \mathrm{~km}^{2}$. These areas are small in comparison with hydrocarbon and groundwater subsidence areas, which are one to two orders of magnitude larger (Atherton et al, 1976). 
TABLE B-3 - COMPARISON OF GEOTHERMAL SUBSIOENCE AREAS

(from Atherton et a 1, 1976)

\begin{tabular}{|c|c|c|c|}
\hline & $\begin{array}{l}\text { Mairakei } \\
\text { Mew Zealand }\end{array}$ & $\begin{array}{l}\text { Broadlands } \\
\text { Men Zealand }\end{array}$ & $\begin{array}{l}\text { Kowerou } \\
\text { New Zed land }\end{array}$ \\
\hline \multicolumn{4}{|l|}{ SURFACE DEFORMATION } \\
\hline \multicolumn{4}{|l|}{ Subsidence } \\
\hline $\begin{array}{l}\text { Area Affected } \\
\text { Maximum Subsidence } \\
\text { Subsidence Rate }\end{array}$ & $\begin{array}{l}65 \mathrm{~km}^{2}(1956-1970) \\
4.7 \mathrm{~m}(1956-1974) \\
\text { Mox. } 40-45 \mathrm{~cm} / \mathrm{yr}(1967-1974)\end{array}$ & $\begin{array}{l}73 \mathrm{~km}^{2}(1969-1975) \\
0.175 \mathrm{~mm}(1969-1975) \\
7.5 \mathrm{~cm} / \mathrm{yr}(1969-1972)\end{array}$ & $\begin{array}{l}-1 \mathrm{~km}^{2} \\
0.028(1970-1971) \\
\max .2 .8 \mathrm{~cm} / \mathrm{yr}(1970-1972)\end{array}$ \\
\hline \multicolumn{4}{|l|}{ Morizontal Movement } \\
\hline $\begin{array}{l}\text { Maximum Novement } \\
\text { Rote }\end{array}$ & $\begin{array}{l}0.8 \mathrm{~m}(1956-1974) \\
\operatorname{Max} .-10 \mathrm{~cm} / \mathrm{yr}(1970)\end{array}$ & $\begin{array}{l}0.12 \mathrm{~m}(1969-1975) \\
\text { Avg. } 2 \mathrm{~cm} / \mathrm{yr}(1969-1975)\end{array}$ & Not medsured \\
\hline Associated faulting & Mone & Mone & None \\
\hline Time of Principal Oecurrence & $1953-1976+$ & $1966-1976+$ & $1956-1976+$ \\
\hline \multicolumn{4}{|l|}{ RESERYOIR MATERIALS } \\
\hline Type. Age. Consolidation & $\begin{array}{l}\text { Punice breccia with sands tone } \\
\text { and minor silts tone, medial } \\
\text { rhyolite sili. Pleis tocene }\end{array}$ & $\begin{array}{l}\text { Punice breccia and tuff, } \\
\text { Plelstocene, with mediai } \\
\text { siltstone and rhyolite } \\
\text { dquit tards, Pleistocene }\end{array}$ & $\begin{array}{l}\text { Pumice breccio and ignimorite, } \\
\text { with medial andes } 1 \text { te sills. } \\
\text { Pleistocene }\end{array}$ \\
\hline Porosity & $\begin{array}{l}\text { Extremely varlable due to } \\
\text { cementation }\end{array}$ & $\begin{array}{l}\text { 15-50: (highest in } \\
\text { punice breccta) }\end{array}$ & \\
\hline Permeablitity & $\begin{array}{l}: 1-30 \text { mo (intergranular) } \\
: 10 \text { (fracture) }\end{array}$ & Moderately high & \\
\hline Compaction Beharior & $\begin{array}{l}\text { Maximum substidence outside } \\
\text { area of greatest production. } \\
\text { Local sills of volcanic rock } \\
\text { may prevent transfer of load } \\
\text { to underiying reservoir }\end{array}$ & & \\
\hline \multicolumn{4}{|l|}{ OYERBURDEN } \\
\hline $\begin{array}{l}\text { Type, Competence. } \\
\text { Deformation Properties }\end{array}$ & $\begin{array}{l}\text { Tuffoceous shale and sand- } \\
\text { stone with incerbedded tuff } \\
\text { and conglomerace. Pleis tocene }\end{array}$ & $\begin{array}{l}\text { Chiefly silts tone, mud- } \\
\text { stone, and rhyolite with } \\
\text { minor sands tone, tuff } \\
\text { and slluvilum, Pieis tocene }\end{array}$ & $\begin{array}{l}\text { Pleistocene rhyolite flows and } \\
\text { Holocene (i) alluvium }\end{array}$ \\
\hline \multicolumn{4}{|l|}{ REGIOMLL GEOLOGIC STRUCTURE } \\
\hline $\begin{array}{l}\text { Folding, Faulting. Regiond } \\
\text { Stress }\end{array}$ & $\begin{array}{l}\text { Sediments drape-folded over } \\
\text { basement highs, normal } \\
\text { foult tho with } 3 \text { mall compo- } \\
\text { ment of right-1ateral move- } \\
\text { ment, indicates tensile } \\
\text { stress }\end{array}$ & $\begin{array}{l}\text { Mormat foulting, with } \\
\text { small component of } \\
\text { right-lateral movement, } \\
\text { indicates tensile stress }\end{array}$ & $\begin{array}{l}\text { Numerous normal foults, with amall } \\
\text { componene of right-lateral move- } \\
\text { ment. indsating tensile stress }\end{array}$ \\
\hline \multicolumn{4}{|l|}{ PROOUCTION } \\
\hline $\begin{array}{l}\text { Depth } \\
\text { Fluid Type }\end{array}$ & $\begin{array}{l}150-1360 \mathrm{~m} \\
\text { Hot water and flashed } \\
\text { steam }\end{array}$ & $\begin{array}{l}430-1200 \mathrm{~m} \\
\text { Hot water and flashed } \\
\text { steam }\end{array}$ & $\begin{array}{l}460-915 \mathrm{~m} \\
\text { Hot water and flashed stean }\end{array}$ \\
\hline Temperature & $\operatorname{Max} 1 \mathrm{mum} 260^{\circ} \mathrm{C}$ & Maximum $300^{\circ} \mathrm{C}+$ & Maximum $2700^{\circ} \mathrm{C}+$ \\
\hline Production Rate & $1.3 \times 10^{7} \mathrm{~kg} / \mathrm{doy}(1975)$ & $\underset{(1973-1975)}{2.63 \times 10^{7}} \mathrm{~kg} / \mathrm{doy}$ & $\operatorname{Max}, 1.6 \times 10^{7} \mathrm{~kg} /$ day $(1956-1970)$ \\
\hline Total Fluld Withdrawal & $930 \times 10^{9} \cdot \mathrm{kg}(1956-1974)$ & & \\
\hline Maximum Pressure Deciline & $25 \mathrm{~kg} / \mathrm{cm}^{2}(1956-1974)$ & & \\
\hline Substdence: Head Deciline & $.02(1956-1974)$ & & \\
\hline
\end{tabular}

Sources: Grindley, 1964, 1970; Sttlwell and others, 1975. 
The configuration of a subsided area is generally that of a bowl.

Figure B-1 contains three subsidence contour maps from which bow1-shaped depressions can be visualized. The deepest areas usually coincide with areas of fluid withdrawal, although this is not the case at Wairakei, as shown in Figure $B-i c$. 




Figure B-la - Wilmington 0i1 Field

(Atherton et al, 1976)

$\stackrel{p}{1}$

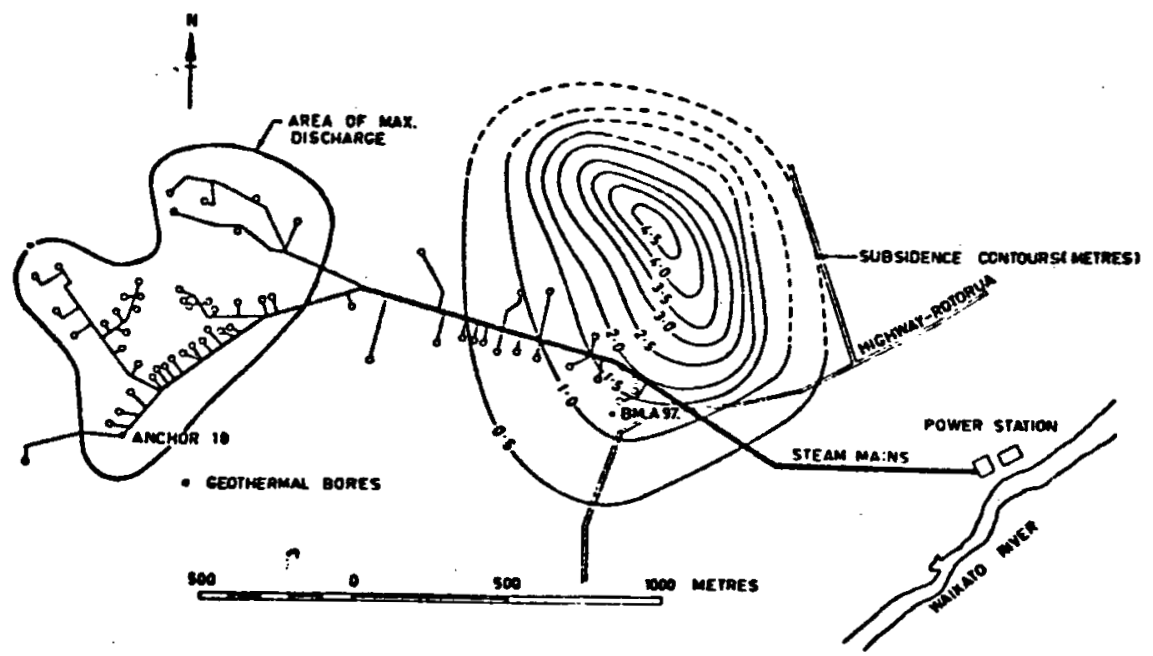

Figure B-lc - Wairakei Geothermal Field

(Stilwel1, Ha11, and Tawhai, 1975)

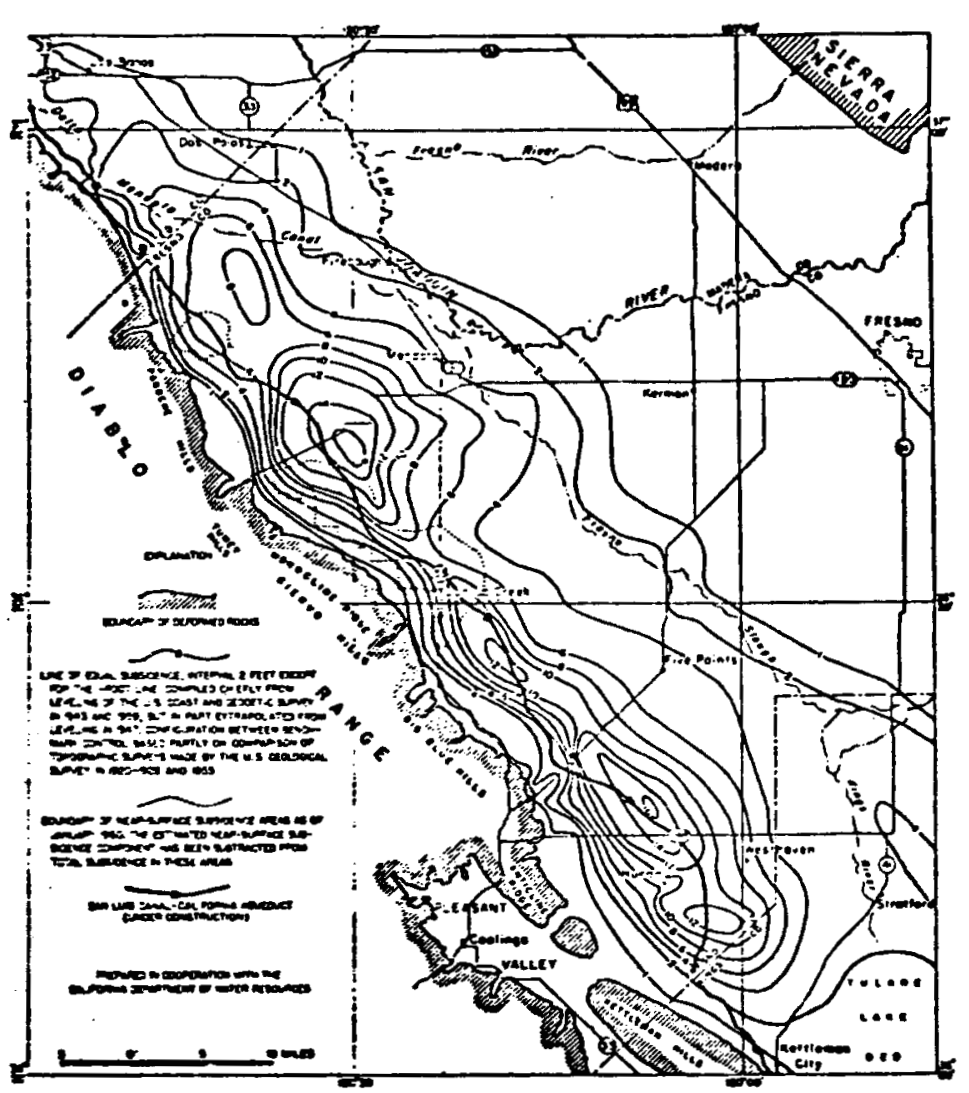

Figure B-1b - San Joaquin Valley

(Poland and Davis, 1969)

FIGURE B-1 - SUBSIDENCE CONTOURS

a) Wilmington 0il Field, California

b) San Joaquin Valley, California

c) Wairakei Geothermal Field, New Zealand 


\section{1 OBJECTIVE OF SPECIFICATIONS}

The guidelines for preparing specifications outlined in this section are based on providing minimum standards for a monitoring system to provide meaningful data. Specifications for systems for detecting damaging levels of movements, and methods for distinguishing different sources of movements are presented. Guidelines for selection of monitoring techniques and the required instrumentation are also discussed.

The specifications are based on summaries of the data and information found in the literature; with engineering judgment applied to supplement incomplete data, where necessary.

\section{C.2 USEFUL MEASUREMENTS FOR MONITORING SUBSIDENCE}

Vertical and horizontal movements are the two primary measurements that are directly recorded. Differential settlements, distortions, horizontal strains, and subsidence profiles can be determined from these measurements. Tilt can be measured directly, but it can also be determined from measurements of vertical and horizontal movements.

\section{3 RANGE AND ACCURACY OF MEASUREMENTS}

\section{C.3.1 Maximum Range of Subsidence}

The expected ranges of horizontal and vertical movements from various sources are presented in Table $\mathrm{C}-1$, which is a summary of the data on maximum and minimum movements obtained from the literature. The values of maximum movement and of maximum rate of movement presented in this table do not necessarily correspond to the same occurrence. Data on landslides are taken from Kennedy and Niermeyer (1970). 
TABLE C-1 - RANGES OF MOVEMENTS

\begin{tabular}{|c|c|c|c|c|c|c|c|c|}
\hline \multirow{2}{*}{$\begin{array}{l}\text { Type of } \\
\text { Source } \\
\text { of } \\
\text { Movemement }\end{array}$} & \multicolumn{2}{|c|}{$\begin{array}{l}\text { Vertical } \\
\text { (meters) }\end{array}$} & \multicolumn{2}{|c|}{$\begin{array}{c}\text { Vertical Rate } \\
(\mathrm{cm} / \text { year })\end{array}$} & \multicolumn{2}{|c|}{$\begin{array}{c}\text { Horizontal } \\
\text { (meters) }\end{array}$} & \multicolumn{2}{|c|}{$\begin{array}{c}\text { Horizontal Rate } \\
(\mathrm{cm} / \text { year) }\end{array}$} \\
\hline & Max. & Min. & $\operatorname{Max}$. & Min. & Max. & Min. & Max. & Min. \\
\hline $\begin{array}{l}\text { Hydrocarbon } \\
\text { Production }\end{array}$ & 8.8 & $.3-3.3$ & $33-72$ & $.1-.3$ & 3.7 & 0.76 & 11 & 2.6 \\
\hline $\begin{array}{l}\text { Ground Water } \\
\text { Production }\end{array}$ & 9.15 & 0.2 & $15-72$ & 0.4 & - & -- & -- & -- \\
\hline Tectonism & 0.911 & -- & $0.1-1.52$ & -- & 1.521 & - & -- & -- \\
\hline $\begin{array}{l}\text { Collapsing } \\
\text { Soils }\end{array}$ & 4.1 & -- & -- & $\cdots$ & -- & -- & -- & -- \\
\hline Soil Oxidation & -- & - & $0.49^{3}$ & -- & -. & -- & -- & -- \\
\hline $\begin{array}{l}\text { Underground } \\
\text { Mining }\end{array}$ & 1.214 & -- & -- & -- & $0.2^{4}$ & -- & -- & - \\
\hline Lands lides & -- & -- & $\begin{array}{l}1.3 \mathrm{~m} / \mathrm{hr} \\
19-46 \mathrm{cr}\end{array}$ & $\begin{array}{l}5 . \cdot 2-.^{5} \\
1 / \text { day }\end{array}$ & $\mathrm{cm} / \mathrm{day}$ & -- & -- & -- \\
\hline $\begin{array}{l}\text { Geothermal } \\
\text { Production }\end{array}$ & 4.7 & .028 & $40-45$ & 2.8 & 0.8 & 0.12 & 10 & 2 \\
\hline
\end{tabular}

'Subsidence caused by vibration, earthquake did not cause a line of surface rupture.

2 Typical rates involving broad areas.

${ }^{3}$ Average rate of drainage project in Florida.

4Maximum measured in U.S.

${ }^{5} 13$ minutes before failure.

${ }^{6} 1$ year prior to fallure.

71 week prior to failure. 


\section{C.3.2 Survey Accuracy}

First order methods have been most of ten used for surveying of regional vertical control networks, and second order methods have been used for establishing and monitoring the local network. An exception was at Wairakei where the rate of subsidence was so large that second-order leveling did not produce sufficiently rapid results in the production area, so a change was made to double-leveling, which resulted in a surveying production rate of $4.8 \mathrm{~km} /$ day (Holton, 1970). Horizontal control surveys are performed by means of either triangulation or trilateration. Triangulation is based on the establishment of a base line of known length and extending the survey by measurement of the angles of a series of interconnected triangles. In trilateration, the extension is by measurement of the sides of the triangles. At Imperial Valley, geodolite equipment with an accuracy of 1 in 10,000,000 was used for regional monitoring and electronic distance meters (EDM's) with an accuracy of 1 in 2,000,000 were used for monitoring smaller areas (Lofgren, 1974). At the Geysers, EDM's were used for both regional and production area measurements with accuracies of 1 in 10,000,000 regionally and 1 in 100,000 in the production area (Lofgren, 1973). Theodolites accurate to decimals of a second of arc and EDM's accurate to $5 \mathrm{~mm} \pm 1 \mathrm{~mm}$ per $\mathrm{km}$ were used at the Broadlands in New Zealand.

One of the purposes for monitoring production areas is to recognize differential movement of damaging magnitudes. Table $\mathrm{C}-2$ lists the maximum allowable settlements for various types of structures. From a review of this table, it can be seen that the accuracy required to measure potentially damaging movements is a function of the type of structure being monitored.

Preliminary values of expected maximum ranges and maximum rates of movement, and the accuracy which should be achieved in the monitoring measurements if these movements are to be detected, are presented below by source of movement. The values of range and rate of movement are based on reports of field measurements; the accuracy is interpreted from the rate of movement expected and the effects of movements on 


\section{TABLE C-2 - LIMITING SETTLEMENTS}

\begin{tabular}{|c|c|c|}
\hline Type of movernent & Limiting factor & $\begin{array}{l}\text { Maximum } \\
\text { settlement }\end{array}$ \\
\hline Differential movement. & $\begin{array}{l}\text { Drainage } \\
\text { Access } \\
\text { Probability of nonuniform settlement: } \\
\text { Masonry walled structure } \\
\text { Framed structures } \\
\text { Smokestacks, silos, mats } \\
\text { Stability against overturning } \\
\text { Tilting of smokestacks, towers } \\
\text { Rolling of trucks, etc. } \\
\text { Stacking of goods } \\
\text { Machine operation-cotton loom } \\
\text { Machine operation-turbogenerator } \\
\text { Crane rails } \\
\text { Drainage of floors } \\
\text { High continuous brick walls } \\
\text { One-story brick mill building, wall } \\
\text { cracking } \\
\text { Plaster cracking (gypsum) } \\
\text { Reinforced-concrete building frame } \\
\text { Reinforced-concrete building curtain } \\
\text { walls } \\
\text { Steel frame, continuous } \\
\text { Simple steel frame }\end{array}$ & $\begin{array}{l}6 \text { to } 12 \text { in. } \\
12 \text { to } 24 \text { in. } \\
1 \text { to } 2 \text { in. } \\
2 \text { to } 4 \text { in. } \\
3 \text { to } 12 \text { in. } \\
\text { Depends on height } \\
\text { and width } \\
0.004 b \\
0.01 L \\
0.01 L \\
0.003 L \\
0.0002 L \\
0.003 L \\
0.01 \text { to } 0.02 L \\
0.0005 \text { to } 0.001 L \\
0.001 \text { to } 0.002 L \\
\\
0.001 L \\
0.0025 \text { to } 0.004 L \\
0.003 L \\
\\
0.002 L \\
0.005 L\end{array}$ \\
\hline
\end{tabular}

Note: $L=$ distance between adjacent columns that settle different amounts, or between any two points that settle differently. Higher values are for regular settlements and more tolerant structures. 'Lower values are for irregular settlements and critical structures. 
environmental and structural features. A considerable amount of judgment was required where data were not available. The stated accuracy cannot in every case be obtained by first or second order survey methods, and more precise methods may be required if detecting the very slow rates of movement is considered significant.

1. Petroleum and Groundwater Production Areas

Range: $\quad 10 \mathrm{~m}$ vertical; $1 \mathrm{~m}$ horizontal

Rate: $\quad 0.7 \mathrm{~m} /$ year vertical; $0.1 \mathrm{~m} /$ year horizontal

Accuracy: $\pm 3 \mathrm{~mm}$ vertical; $\pm 1.5 \mathrm{~mm}$ horizontal

2. Geothermal Production Areas

Liquid-Dominated

Range: $\quad 5 \mathrm{~m}$ vertica 1; $1 \mathrm{~m}$ horizontal

Rate: $\quad 0.25 \mathrm{~m} /$ year vertical; $0.05 \mathrm{~m} /$ year horizontal

Accuracy: $\pm 1.0 \mathrm{~mm}$ vertical; $\pm 0.5 \mathrm{~mm}$ horizontal

Steam-Dominated

Range: $\quad 0.25 \mathrm{~m}$ vertical; $0.05 \mathrm{~m}$ horizontal

Rate: $\quad 20 \mathrm{~mm} /$ year vertical; $10 \mathrm{~mm} /$ year horizontal

Accuracy: $\pm 0.5 \mathrm{~mm}$ vertical and horizontal

3. Tectonic Movements

Non-Earthquake Induced

Range: $\quad 2 \mathrm{~m}$ vertical and horizontal

Rate: $\quad 10 \mathrm{~mm} /$ year vertical

Accuracy: $\pm 0.5 \mathrm{~mm}$ vertical and horizontal

Earthquake Induced

Range: $\quad 13 \mathrm{~m}$ vertical; $2 \mathrm{~m}$ horizontal

Rate: Not applicable since movement is almost instantaneous to maximum range

Accuracy: $\pm 3 \mathrm{~mm}$ vertical; $\pm 1.5 \mathrm{~mm}$ horizontal

4. Collapsing Soil

Range: $\quad 5 \mathrm{~m}$ vertical; $2 \mathrm{~m}$ horizontal

Rate: $\quad 2 \mathrm{~m} /$ year vertica $1 ; 0.5 \mathrm{~m} /$ year horizontal (induced)

Accuracy: $\pm 5 \mathrm{~mm}$ vertical; $\pm 1.5 \mathrm{~mm}$ horizontal 
5. Soil Oxidation

$$
\begin{array}{ll}
\text { Range: } & 50 \% \text { of thickness of deposit vertical; } \\
& 5 \% \text { of thickness of deposit horizontal } \\
\text { Rate: } & 30 \mathrm{~mm} / \text { year vertical } \\
\text { Accuracy: } & \pm 5 \mathrm{~mm} \text { vertical; } \pm 1.5 \mathrm{~mm} \text { horizontal }
\end{array}
$$

6. Landslides, Underground Mining

$$
\begin{array}{ll}
\text { Range: } & 2 \mathrm{~m} \text { vertical and horizontal (occasionally } \\
& \text { considerably more) } \\
& 1 \mathrm{~m} / \text { year vertical and horizontal (occasionally } \\
\text { Rate: } & \text { landslide rates considerably more rapid) } \\
\text { Accuracy: } & \pm 2 \mathrm{~mm} \text { vertical and horizontal }
\end{array}
$$

7. Multiple Sources

Range: Square root of sum of squares of component ranges Rate: Square root of sum of squares of component rates Accuracy: Equal to that of most accurate of sources

\section{4 MONITORING NETWORKS}

The networks for monitoring subsidence include a regional network and a local network. The regional network provides a stable datum; and the local network monitors movements in and adjacent to the production area in relation to the regional network.

\section{C.4.1 Regional Networks}

To obtain the accuracy needed, first-order leveling should be used for vertical measurements in the regional network. A summary of some of the standards for vertical control surveys is presented in Table C-3. Since the recommended spacing for such lines is 100 to $300 \mathrm{~km}$, and a geothermal field may be on the order of only $100 \mathrm{~km}^{2}$, location and spacing of regional control network monuments is based on requirements of the monitoring operation rather than survey accuracy. If a suitable network is already established in the area and is accessible, it may not be necessary to set up additional monuments for the regional network. For example, at the Geysers in California, a level line was run between two existing first-order lines, with a loop within the production area (Figure $\mathrm{C}-1$ ). 
TABLE C-3 - SUMMARY OF STANDARDS FOR VERTICAL CONTROL SURVEYS*

(After Moffitt and Bouchard, 1975)

Survey Classification

First Order

Second Order

Third Order

Related uses

Control network;

Subsidence moni-

Supp Tementary regional tectonic toring networks subsidence movements

measurements

Ins truments

Automatic or tilting levels

with parallel

plate micrometers;

invar scale rods

Automatic, tilting, or geo-

Geodetic levels detic levels;

invar scale rods

and rods

Maximum length of
sight

Maximum closures

( $K=$ distance in kilometers)

50 meters (Cl. I);

60 meters (CI. II)

60 meters ( $\mathrm{Cl} . \mathrm{I})$

90 meters

70 meters (Cl.II)

$3 \mathrm{~mm} \sqrt{\mathrm{K}}(\mathrm{Cl}$. I);

$6 \mathrm{~mm} \sqrt{\mathrm{K}}(\mathrm{Cl} . \mathrm{I})$;

$12 \mathrm{~mm} \sqrt{\mathrm{K}}$

$5 \mathrm{~mm} \sqrt{\mathrm{K}}(\mathrm{Cl}$. II $)$

$8 \mathrm{~mm} \sqrt{\mathrm{K}}(\mathrm{CL}$. II $)$

*Standards are subject to change. Before using, check current publications. 


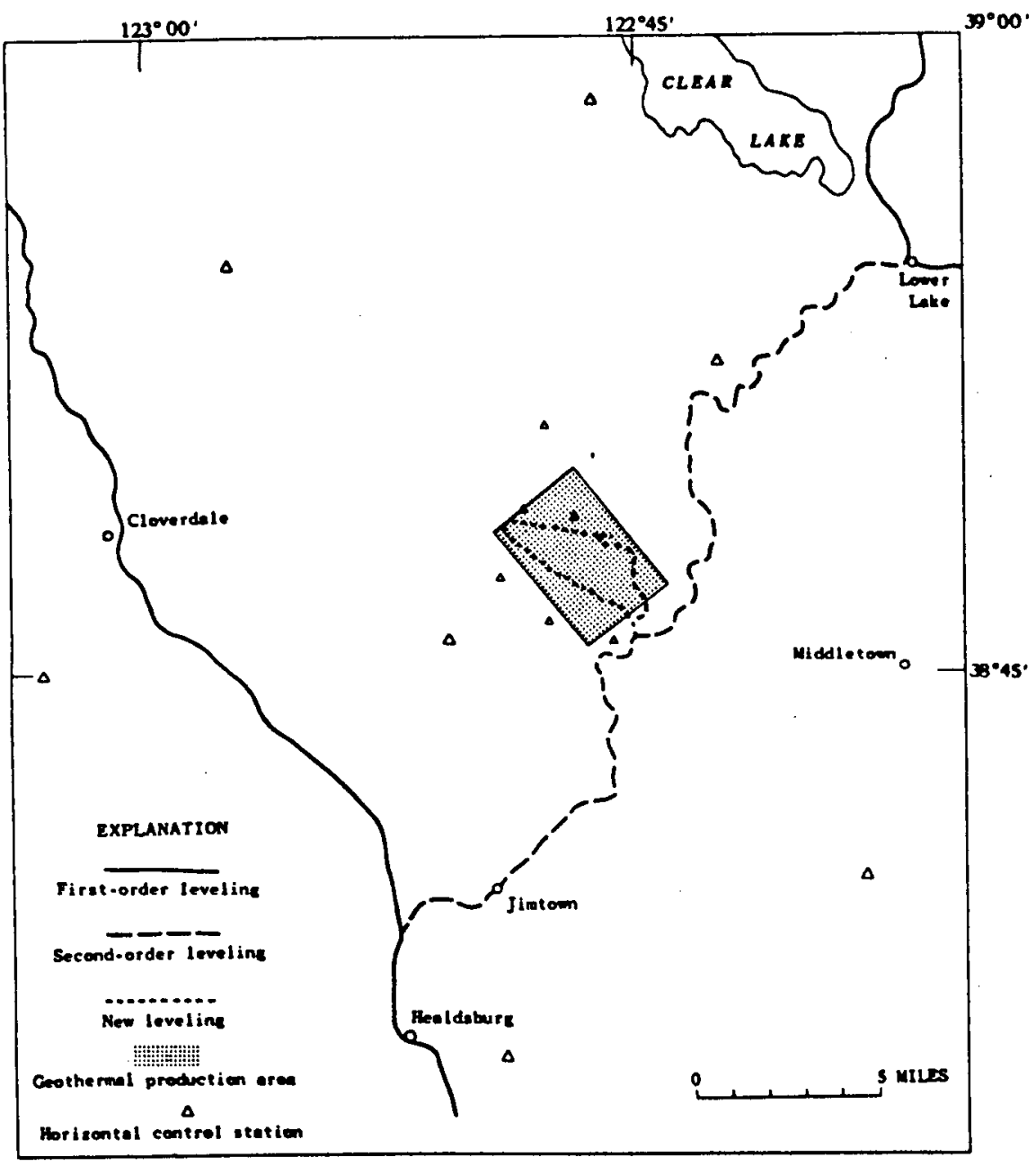

(Lofgren, 1973)

FIGURE C-1 - REGIONAL VERTICAL CONTROL NETWORK THE GEYSERS AREA, CALIFORNIA 
For horizontal control, two general types of triangulation networks are used, the arc or chain network (Figure $\mathrm{C}-2$ ) and the area network (Figure $\mathrm{C}-3)$. Although referred to as triangulation networks, trilateration or a combination of triangulation and trilateration survey methods may be used in either arc or area networks. Arc networks are generally used for establishing horizontal control on a national level or for a very large region. Area networks are normally used for smaller regions, such as county surveys, and are usually tied into an arc network (Moffitt and Brouchard, 1975). Figure C-4 shows the horizontal controls established at the Geysers, which is basically an area network tied to an arc network. Figure $\mathrm{C}-5$ shows the area network tied into an arc network used at Kawerau, New Zealand.

Because of speed and accuracy of surveying for this type, area networks are usually appropriate as the regional network for horizontal control. Arc network methods may be used to extend control to the region, to provide a base for an area network. The accuracy for such networks should be that of first-order horizontal control surveys (Tables C-4a and $C-4 b)$.

The location of vertical control bench marks and of horizontal control stations for regional networks are determined primarily by the needs of the monitoring operation. Four objectives to consider when locating bench marks and stations are 1) accessibility for monitoring surveys; 2) location such that the data obtained will be meaningful; 3) stability of mounting, e.g., in bedrock or heavy structure; and 4) minimum possibility of loss through production expansion, construction activities, landslides, or other events.

\section{C.4.2 Local Networks}

The following discussion is directed primarily to monitoring of subsidence in geotherma 1 areas, including the subsidence in such areas which may be attributable to sources other than geothermal production. Monitoring of potential landslide areas is discussed separately. 




(Moffitt and Brouchard, 1975)

FIGURE C-2 - ARC TRIANGULATION 


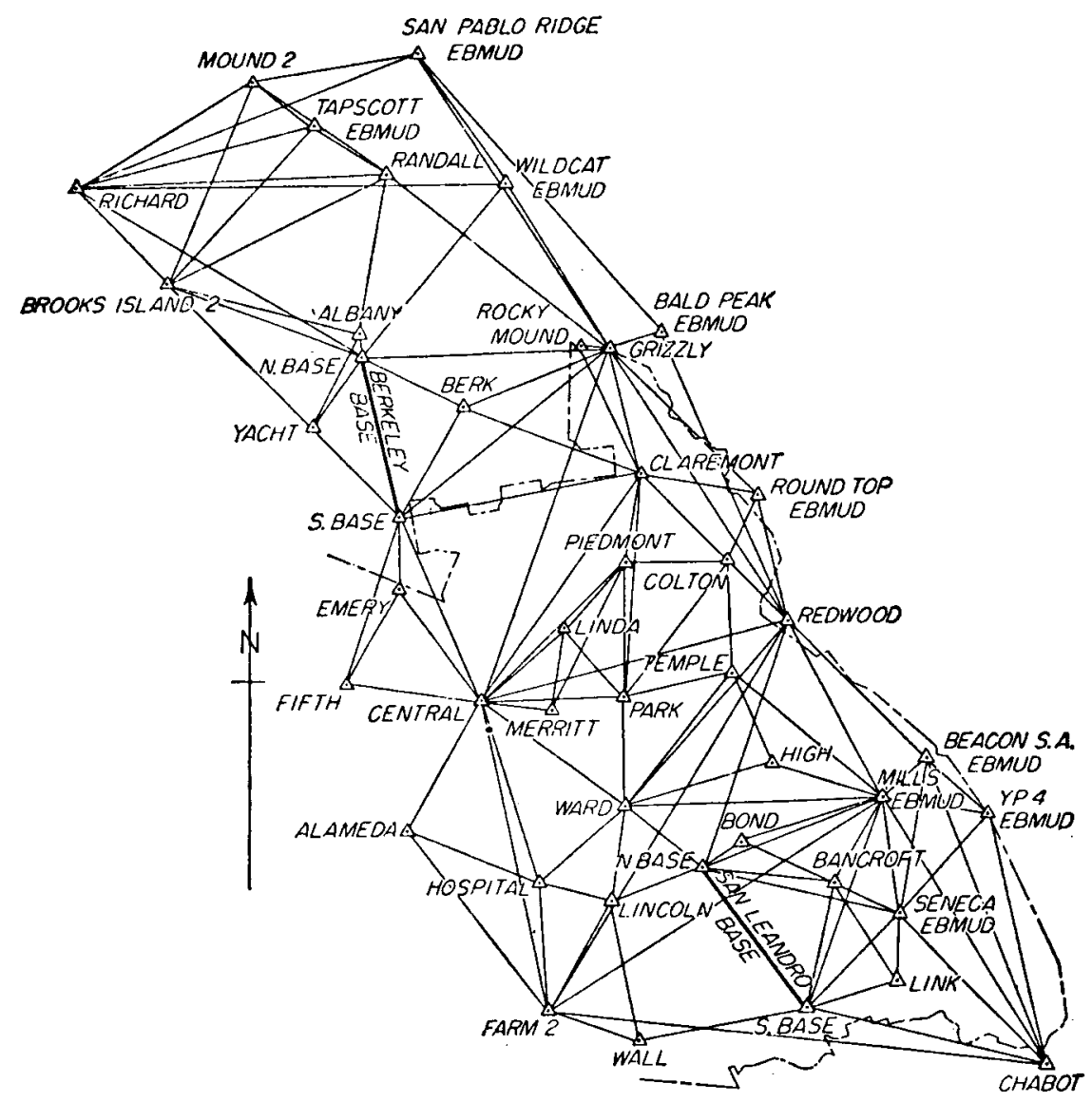

(Moffitt and Brouchard, 1975)

FIGURE C-3 - TRIANGULATION DIAGRAM OF THE CITY OF OAKLAND, CALIFORNIA 


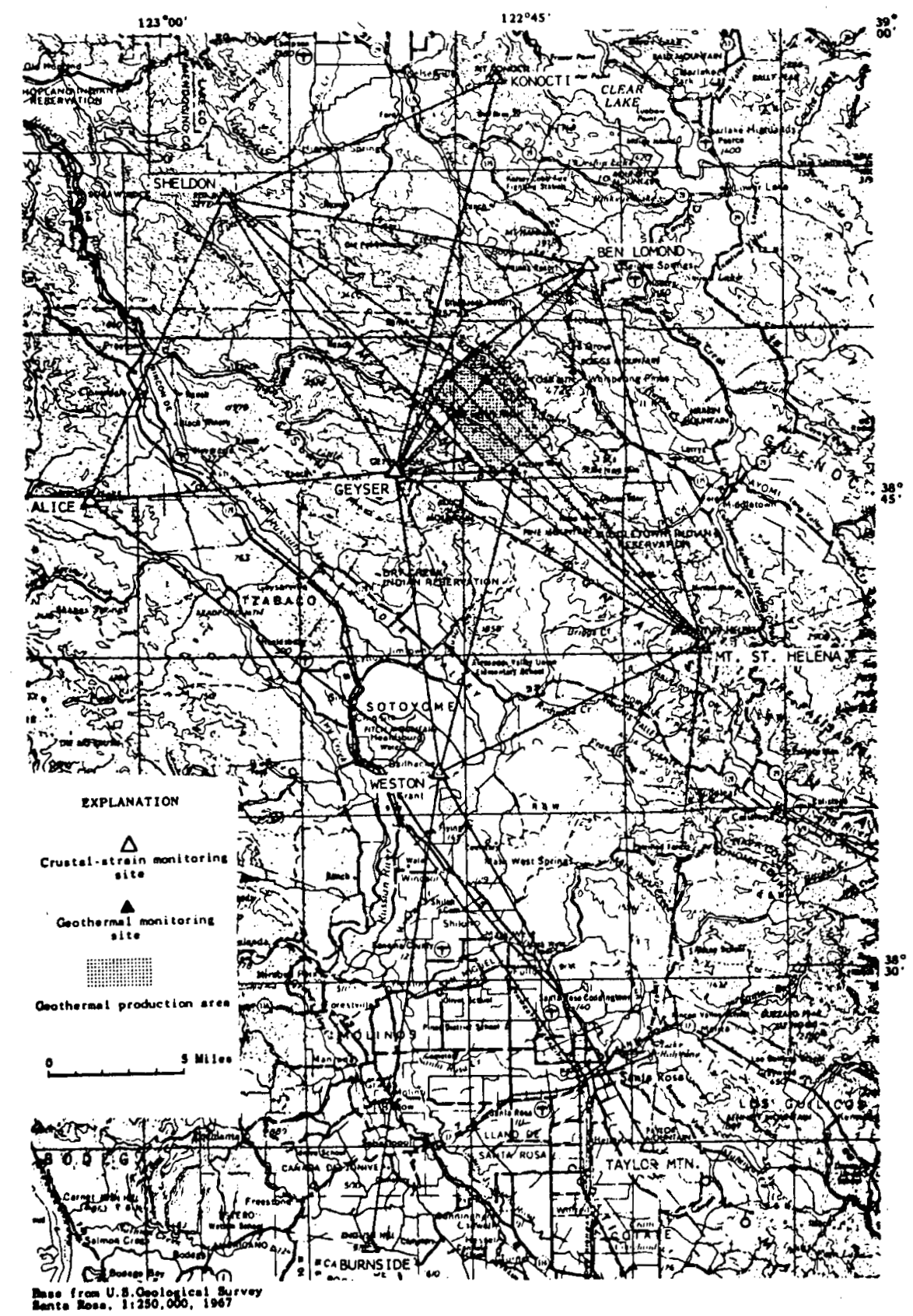

FIGURE C-4 - REGIONAL HORIZONTAL CONTROL

(Lofgren, 1973) 


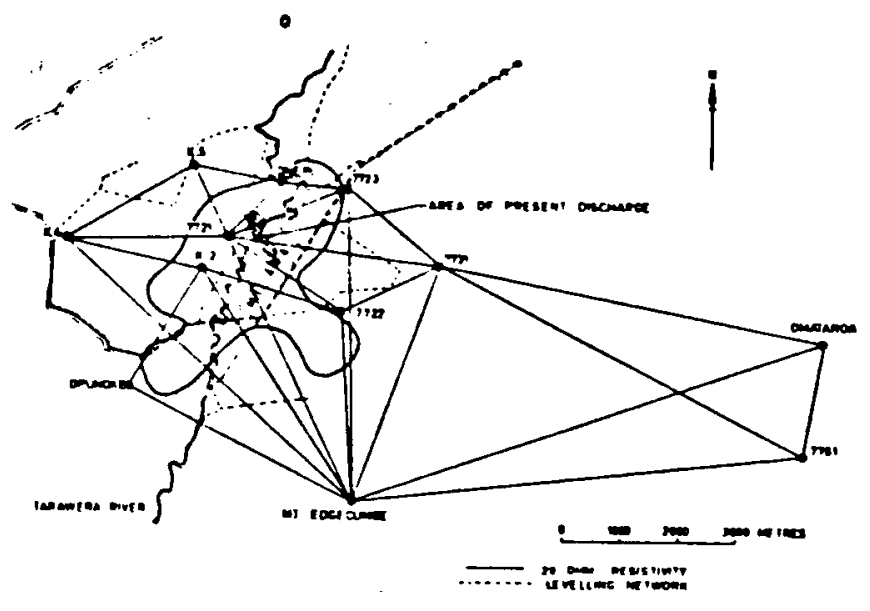

FIGURE C-5 - KAWERAU SURVEY CONTROL (Stilwell et al, 1975) 
TABLE C-4a - SUMMARY OF STANDARDS FOR HORIZONTAL CONTROL SURVEYS - TRIANGULATION

\begin{tabular}{|c|c|c|c|}
\hline Survey Classification & First Order & Second Order & Third Order \\
\hline Base Line Measurement & 1 in $1,000,000$ & $\begin{array}{l}1 \text { in } 900,000 \\
(\mathrm{Cl} . \mathrm{I})\end{array}$ & $\begin{array}{l}1 \text { in } 500,000 \\
(\mathrm{Cl} . \mathrm{I})\end{array}$ \\
\hline Standard Error & & $\begin{array}{l}1 \text { in } 800,000 \\
(\mathrm{Cl} . \mathrm{II})\end{array}$ & $\begin{array}{l}1 \text { in } 250,000 \\
(\mathrm{Cl} . \mathrm{II})\end{array}$ \\
\hline \multicolumn{4}{|l|}{ Triangle Closure } \\
\hline $\begin{array}{l}\text { Average, not to } \\
\text { exceed }\end{array}$ & $1.0^{\prime \prime}$ & $\begin{array}{l}1.2^{\prime \prime}(\mathrm{Cl} . \mathrm{I}) ; \\
2.0^{\prime \prime}(\mathrm{Cl} . \mathrm{II})\end{array}$ & $\begin{array}{l}3.0^{\prime \prime}(\mathrm{Cl} . \text { I }) ; \\
5.0^{\prime \prime}(\mathrm{Cl} . \text { II })\end{array}$ \\
\hline $\begin{array}{l}\text { Maximum, seldom to } \\
\text { exceed }\end{array}$ & $3.0^{\prime \prime}$ & $\begin{array}{l}3.0^{\prime \prime}(\mathrm{C} 1 . \text { I }) ; \\
5.0^{\prime \prime}(\mathrm{Cl} . \text { II })\end{array}$ & $\begin{array}{l}5.0^{\prime \prime}(\mathrm{Cl} . \mathrm{I}) ; \\
10.0^{\prime \prime}(\mathrm{Cl} . \mathrm{II})\end{array}$ \\
\hline Closure in length, & & - & \\
\hline \multirow[t]{2}{*}{ Should not exceed } & 1 in 100,000 & $\begin{array}{l}1 \text { in } 50,000 \\
(C 7 . I) ;\end{array}$ & $\begin{array}{l}1 \text { in 10,000 } \\
\text { (C1. I); }\end{array}$ \\
\hline & & $\begin{array}{l}1 \text { in } 20,000 \\
(\mathrm{CT} . \mathrm{II})\end{array}$ & $\begin{array}{l}1 \text { in } 5,000 \\
(\mathrm{Cl} . \mathrm{II})\end{array}$ \\
\hline
\end{tabular}

TABLE C-4b - SUMMARY OF STANDARDS FOR HORIZONTAL CONTROL SURVEYS - TRILATERATION Survey Classification First Order Second Order Third Order

Minimum Angle in
Geometric Config-
uration

Length Measurement $25^{\circ}$

1 in $1,000,000$ 
Local networks are for monitoring movements in the production area and should extend over the entire area in which movements are expected. In general, this is an area surrounding the points of withdrawal, but is not necessarily so, e.g., at the Wairakei geothermal field the maximum subsidence was some distance from the area of maximum withdrawal.

For monitoring of vertical movements, second order leveling survey procedures will usually provide the necessary accuracy. Second-order leveling should be used during the pre-production period to determine whether movement is occurring from other sources and, if so, to establish the rate of such movement. If rate of movement during production becomes relatively large, the time required to obtain second order accuracy may no longer be justified, and more rapid third order procedures may be used. Should the rate decrease, such as after withdrawal has ceased, second order procedures should be re-instated. The local network should be tied-in to pre-selected regional network monuments each time a vertical survey is made.

The location and spacing of bench marks is based primarily on existing or expected construction in the area, including the geothermal plant; the shape and areal extent of the surface which is to be monitored; and the maximum length of sight for second order vertical control surveys. A bench mark should be placed on each structure which might be damaged by subsidence; more than one should be considered on extended structures, such as long buildings or canals, where differential subsidence might be critical (Table $\mathrm{C}-2$ ). Where there are no structures, spacing of monuments at 120 meters (twice the maximum length of sight for second order leveling) would be efficient from the standpoint of surveying, but would seldom be practical because of the large number of bench marks which would be required to be placed. The shape of the monitoring area might suggest a pattern other than a simple grid. Figure $\mathrm{C}-6$ illustrates a grid pattern that has been altered to more nearly correspond to the monitoring area. 


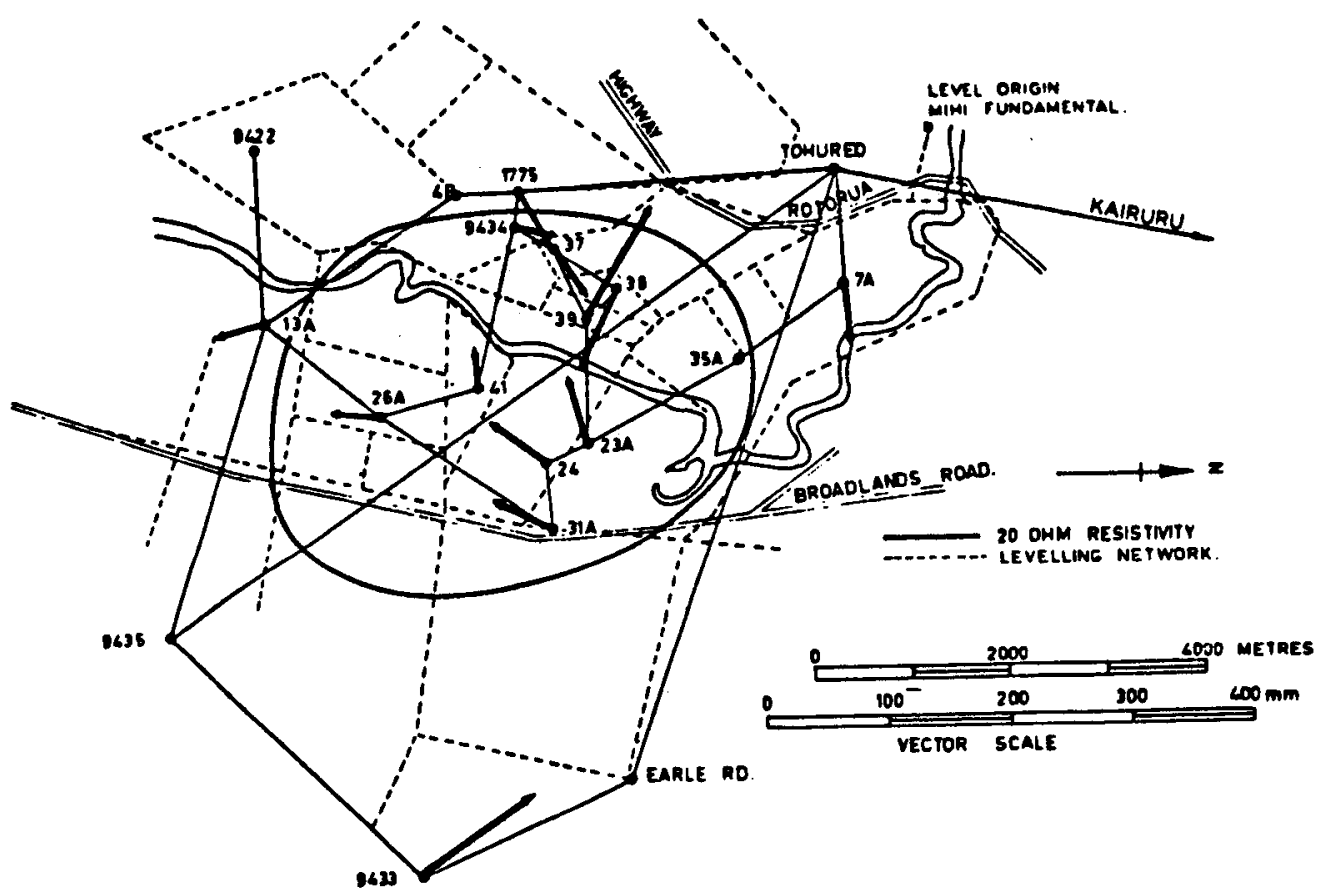

(Stilwell et al, 1975)

FIGURE C-6 - BROADLANDS SURVEY CONTROL NETWORK VECTOR MOVEMENT 1968 TO 1974 
For monitoring of horizontal movements, a second-order area triangulation (or trilateration) network should be established. Location of stations in the network is based primarily on obtaining the strength of figure required by second-order surveying procedures. In general, stations should be the vertical control bench marks. Should ground cracking or horizontal displacement of retaining walls, pipelines, or buildings develop during production, consideration should be given to establishing additional stations for closely monitoring these movements. A tie-in should be made to one or more of the stations in the network. 
APPENDIX D

INSTRUMENTS FOR MONITOR ING

\section{D.1 SURVEYING INSTRUMENTS}

\section{D.1.1 Vertical Measurements}

The engineer's level is found to be adequate and the most practical for vertical measurements required to monitor geothermal subsidence.

Basically it is a telescope with a manual or automatic line-of-sight leveling system on a horizontally-pivoting base mounted on a tripod. A number of important improvements in levels are worth mentioning. For precise leveling over the first order base line circuit, levels equipped with optical micrometers are desirable. The optical micrometer allows the level operator to read graduations on a leveling rod to $0.001 \mathrm{ft}$. Another desirable feature on a precision level is a split-bubble spirit level that may be observed through a separate eyepiece at the time of making a reading on the leveling rod. For more rapid work which does not require quite as much precision in the reading, a self-leveling or automatic compensating level can be used. With this instrument, the observor usually brings the line-of-sight into approximate level, and then an automatic air or magnetic damped compensator takes over. The compensator is an internal pendulum apparatus which maintains a level line-of-sight regardless of the direction to which the instrument is sighted. This is a valuable feature for accurately carrying out rapid work in congested areas, such as expected for the immediate geothermal production well area. For such work, readings are made on leveling rods directly to $0.01 \mathrm{ft}$. and estimated to $0.001 \mathrm{ft}$.

Level rods used in conjunction with levels can be made of wood or fiberglass, and either may have an invar face. Wood is the most durable and least expensive of the rods, fiberglass is the most lightweight. For high-precision leveling, invar rods are widely used, because they are less sensitive to the environment. Most level rods are accurate to about $\pm 0.01 \mathrm{ft}$, and when used with a target and a vernier, accuracy can be improved to about $\pm 0.001 \mathrm{ft}$. 
The elementary procedure of leveling is generally well-known. With the line-of-sight leveled, differences in elevation between two points are determined by observing the relative difference in readings on a graduated rod held vertically on the two points. Generally, a level circuit is begun on a reference elevation bench mark, and is carried sequentially through a series of control points, commonly designated temporary bench marks (TBM), in the region being monitored for vertical movements. The complete procedure for running level circuits is beyond the intended scope of this report. Successful leveling requires personnel with training and experience.

A theodolite (or transit) may be used as a level or by measurement of vertical angles, to determine differences in elevation. However, it would seldom be used for measurement of small vertical movements in subsidence monitoring, because the required accuracy would usually not be obtainable.

\section{D.1.2 Horizontal Measurements}

Monitoring of horizontal movements requires that horizontal distances between points be determined. Distances are determined in surveys either by direct measurement with tape or Electronic Distance Measurement (EDM) instruments; or indirectly by triangulation, i.e., by measurement of angles of a triangle with one side of known length and calculation of the lengths of the other sides.

Although tapes are available in almost any length, 100-foot or 300-foot tapes are commonly used in surveying. For precision work, they are always made of steel. Tapes of a special type of steel (invar) may be used to avoid the requirement for temperature correction, but they must be handled carefully because of the brittle nature of the material, and are relatively expensive. Measurement by tape is an extremely timeconsuming operation, particularly for long distances and steeply sloping terrain. Thus, before the development of the EDM, the procedure used for horizontal surveys consisted of determining the length of a relatively short base line by taping, and expanding the survey over a large area by means of triangulation. 
Although triangulation is still being used, with the development of the EDM direct measurement of distances can now be done rapidly and precisely. The position of unknown points may be determined by trilateration, in which a network of triangles are constructed from a known point or points and the length of all sides are determined directly by means of the EDM. The EDM is a portable, battery-powered apparatus which is mounted on a tripod stationed at one end of the line to be measured. It transmits a beam of light or a series of modulated microwaves to a reflector (or in the case of microwaves, a "remote") mounted on a tripod at the other end of the line. Types of light used are infrared, tungsten, mercury, and laser. The EDM computes the distance to the reflector on the basis of the wavelength of the light used and the integral number of wave lengths in the double distance. By changing the frequency of the transmitted waves, the distance can be determined to as many as four decimal places. A relatively arbitrary classification of the EDM instruments available is made on the basis of their range capabilities. Short range instruments, commonly used infrared, have a range up to $3 \mathrm{~km}$. The intermediate range instruments use tungsten, mercury, or laser light or microwaves and have a.range up to $16 \mathrm{~km}$. The longrange instruments, with a range up to $65 \mathrm{~km}$, use laser light or microwaves almost exclusively. Since air density affects the velocity of light, corrections must be made for air temperature, atmospheric pressure, and relative humidity. In most instruments, these corrections may be processed internally by means of a micro-computer. The accuracy. of measurement also depends on the distance measured. Since error for most instruments is a constant plus a percent of the distance, the percent accuracy improves with distance.

A theodolite (or transit) is an instrument whose primary use is in the measurement of horizontal angles in triangulation surveys. Basically it is a telescope with leveling tube attached to a vertically-pivoting circle, based on a horizontally-pivoting circle with a second leveling tube or bubble. The apparatus is mounted on a tripod for field operations. Both circles are subdivided in degrees of arc, in order that angular differences between successive positions of the telescope may be measured. 
As for the engineers level, the accuracy and speed with which measurements may be made are a function of the design of the instrument and of the operator's degree of skill and careful attention to detail. The accuracy which may be obtained in horizontal control surveys is given in Appendix $\mathrm{C}$, Table $\mathrm{C}-4$.

Recent developments enable the angular displacements on the theodolite to be converted directly to digital readout. The conversion is accomplished by either photoelectric, magnetic, or direct-contact pickup reading of binary codes imprinted on the circles. The signals are sorted electronically and the readings can be displayed and, if desired, stored on magnetic or perforated tape, printed in hard copy, and introduced into a computer. Digital-readout theodolites are available, but not yei widely used.

\section{D.1.3 Photogrammetry}

Photogrammetry is widely used in surveying, chiefly in the use of aerial. photographs to add contour lines and details or man-made features to prepared base maps. The precision required for most aspects of subsidence monitoring cannot be obtained by photogrammetric methods. However, aerial photographs, and maps made from aerial photographs taken several years before the start of the monitoring program, should prove helpful in determining whether or not gross changes in elevation or horizontal position have taken place. For example, fault movements or landslides which have occurred since an old photo was taken or map was made may be evident. For this purpose, the older the photographs or maps, the more likely they are to be of value.

\section{D.2 SPECIAL MONITORING INSTRUMENTS}

Area-wide monitoring may need to be supplemented by special monitoring at a point or over a limited area for which particularly comprehensive and precise data may be desired. Such monitoring may be accomplished by setting additional monuments within the local network, or it may be desirable to make use of certain special-purpose instruments. Instruments which may be applicable to such special purposes include extensometers, tube profile gages, and tiltmeters. 


\section{D.2.1 Extensometers}

Extensometers are used to determine the change in distance between two relatively closely-spaced points. Models are available for subsurface measurements (borehole extensometers) or for surface measurements, as described here. Their primary use has been where relatively high precision is required, such as in crack monitoring. Most surface extensometers are designed for distances of up to 10 to 25 feet, although tape extensometers are made for distances of up to 100 feet. As for tiltmeters, extensometers require special reference points compatible with the device used. Figure $0-1$ shows a type of reference point which consists of a permanent part and a removable part. The permanent part consists of a stainless steel cone with threaded stud which is permanently installed in the field by fastening to objects such as a rebar anchor in a concrete structure or a pipe embedded in concrete. The threaded stud should be covered for protection in situations where it might be damaged. Measurements are made with the extensometer between spherical heads of extension rods which are shaped and threaded to fit the cone and stud.

Extensometers in most common use for surface measurements are the rodtype and the tape-type. The rod type consists of a metal box beam section with plates at each end to fit the reference point used. The measurement is taken with a dial gauge, a machinists scale, or for greater accuracy, a micrometer. An example of a rod extensometer with micrometer is shown in Figure D-2a. The tape extensometer consists of a stee 1 tape attached to a sensor and to a holding device which applies a consistant tension to the tape and the sensor (Figure $D-2 b$ ). The tape extensometer has a much longer displacement range (up to $100 \mathrm{feet}$ ) than the rod type (a few inches); but the accuracy is lower - about \pm 0.01 in. versus \pm 0.0004 in. Both types are temperature sensitive, and temperature corrections must be applied.

\section{D.2.2 Tube Profile Devices}

There are many different types of tube profile gauges. Their primary use has been in the monitoring of vertical movements in inaccessible locations, such as within earth dams or under relatively large and heavy 

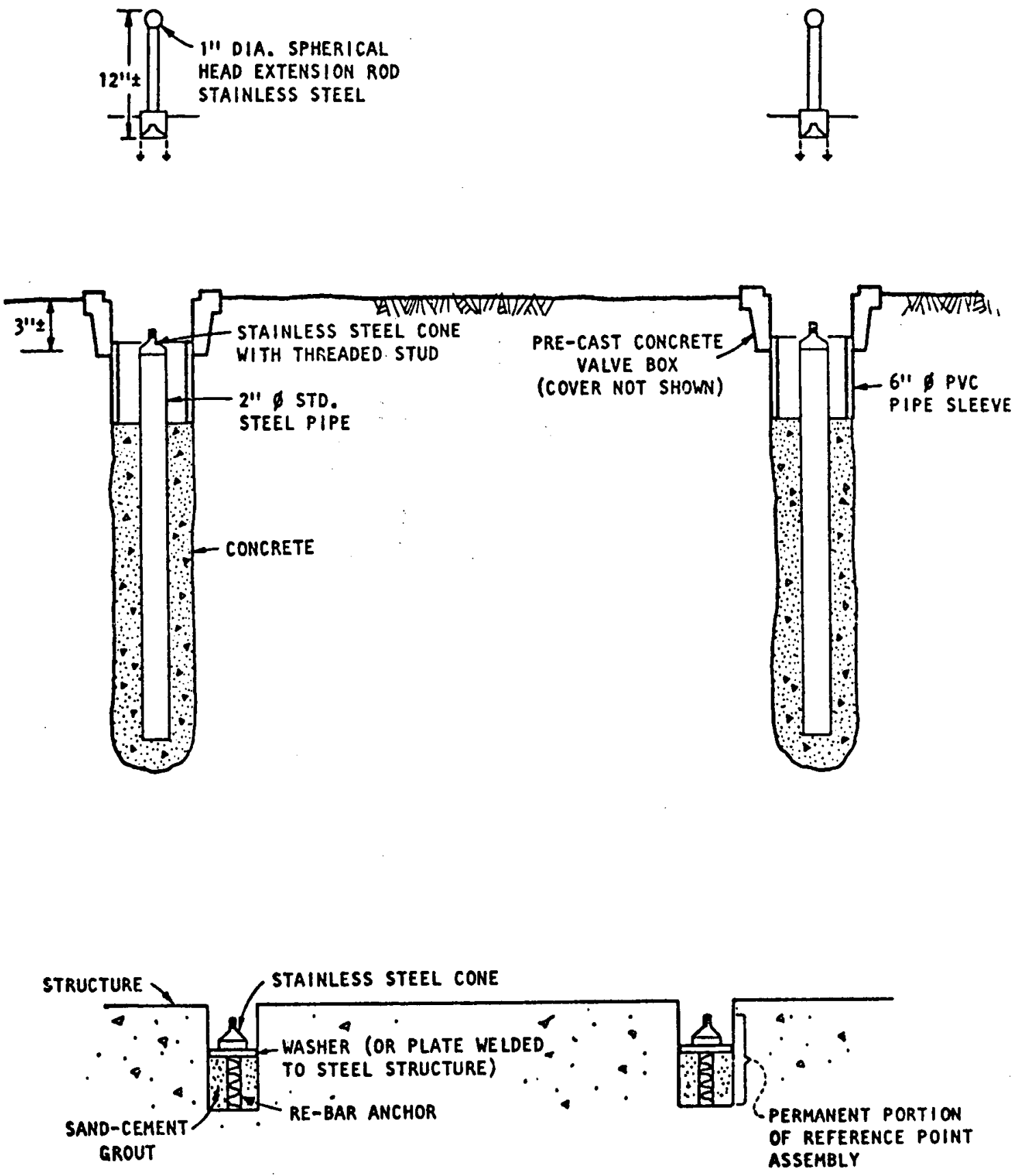

FIGURE D-1 - EXTENSOMETER REFERENCE POINTS

(WCC, 1977B) 


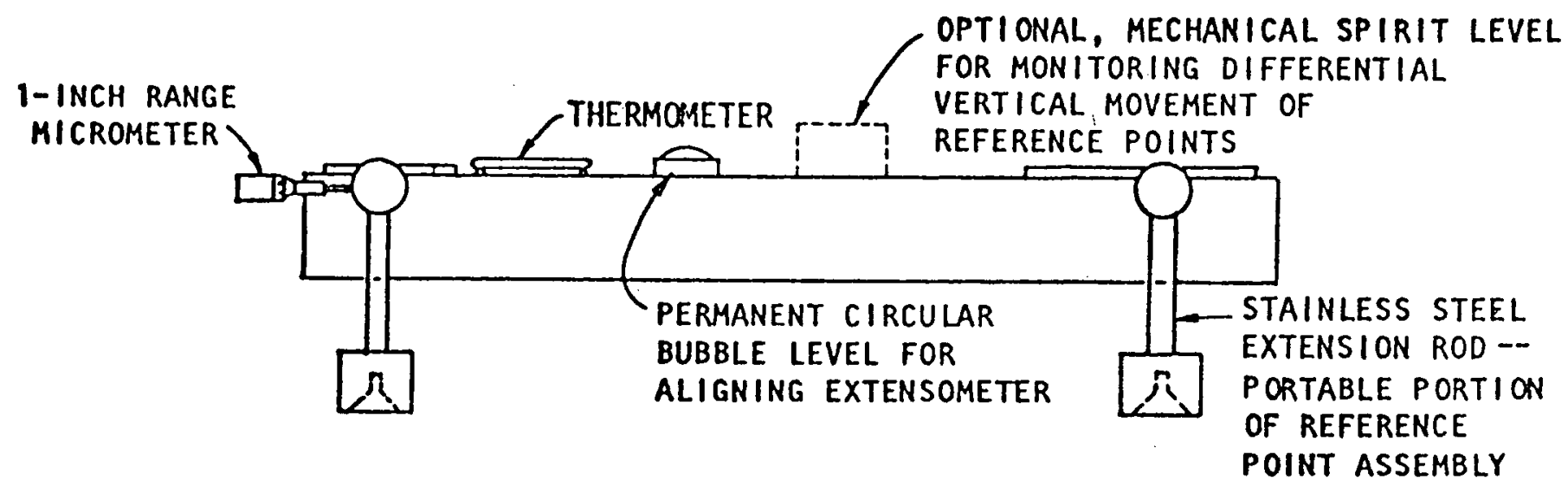

FIGURE D-2a - ROD EXTENSOMETER

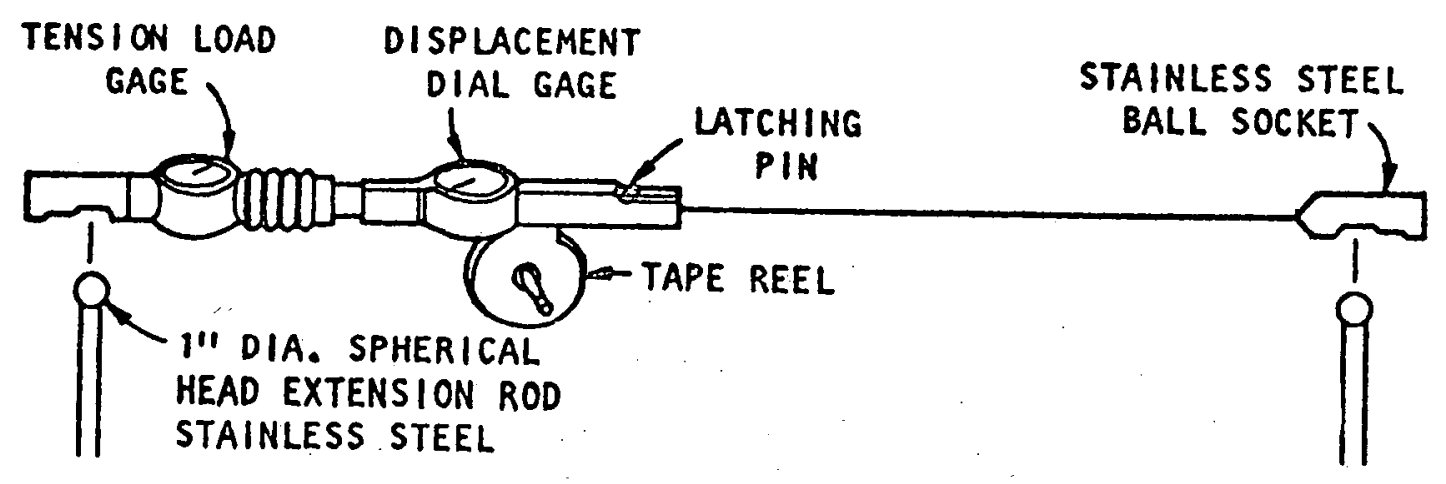

FIGURE D-2b - TAPE EXTENSOMETER

(WCC, 1977B) 
structures such as storage tanks. They may also have cost and convenience advantages for surface subsidence monitoring in congested and inconvenient locations for personnel access, such as well fields. Two of the devices of the type which require a supply of water or other liquid are shown in Figure $D-3$. In Figure $D-3 a$ is a gauge in which water is pumped through the buried tubing, and the elevation of the inaccessible point is determined from the common water level at this point and at the standpipe at the accessible end of the tube. In the device in Figure $D-3 b$, water is also pumped through the buried tubing, but with this device a pressure-sensing probe is used to determine the difference in pressure between any point in the tube and a weir at a known elevation. 0ther devices use a combination of fluids of heavy density (mercury) and of light density (water); elevation is determined by measurement of differential pressure from the fluid interface as it is forced to traverse the tube. Two devices which do not require the use of fluids are presented in Figure D-4. The horizontal movement and settlement gauge shown in Figure $\mathrm{D}-4 \mathrm{a}$ has a two part probe. The front part (settlement gauge) gives the elevation of any point along the buried tubing, while the back part (the movement probe) contains a reed switch which gives a signal as it passes each magnet. The horizontal inclinometer-profiler shown in Figure $D 4-b$ gives a continuous reading of slope as it is pulled through the tube.

Profile gauges are usually expected to function for the life of the structure being monitored. Accuracy varies considerably among the gauge types, with the hydraulic settlement gauge probably the least accurate, about 1/4-inch, and the accuracy of others being highly dependent on the readout equipment used.

\subsubsection{Tiltmeters}

Tiltmeters are single-point station tilt monitoring devices. Permanent and portable type tiltmeters are available, with the latter being more widely used. The permanent models can be either completely encased in the soil/rock mass as in Figure D-5 or mounted on the surface (Figure $D-6)$. The tiltmeter diagramed in Figures $D-5$ and $D-6$ has a vibrating wire transmitter to detect tilt. A remote receiver is used to take readings. 




FIGURE D-3a - HYDRAULIC SETTLEMENT GAUGE

(Soil Instruments Ltd., 1977)






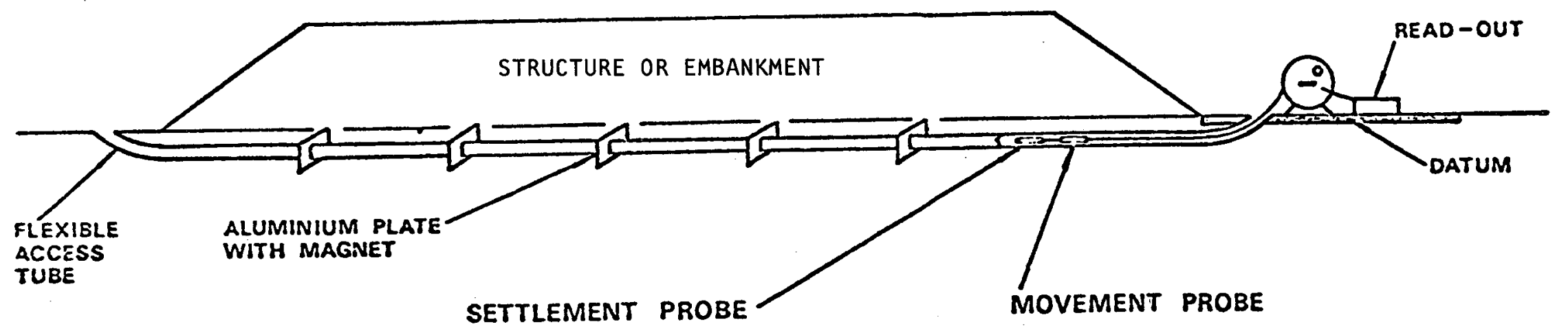

FIGURE D-4a - HORIZONTAL MOVEMENT AND SETTLEMENT GAUGE

(Soil Instruments Ltd., 1977)

$\frac{p}{0}$

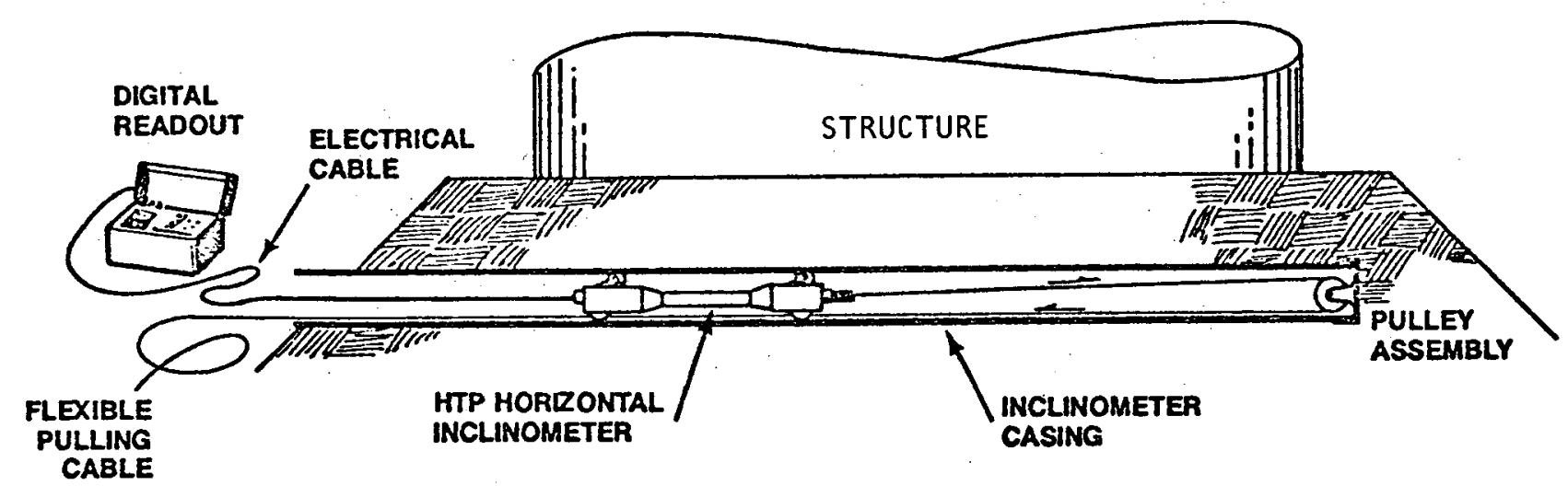

FIGURE D-4b - HORIZONTAL INCLINOMETER - PROFILER

(Terra-Technology, 1977) 


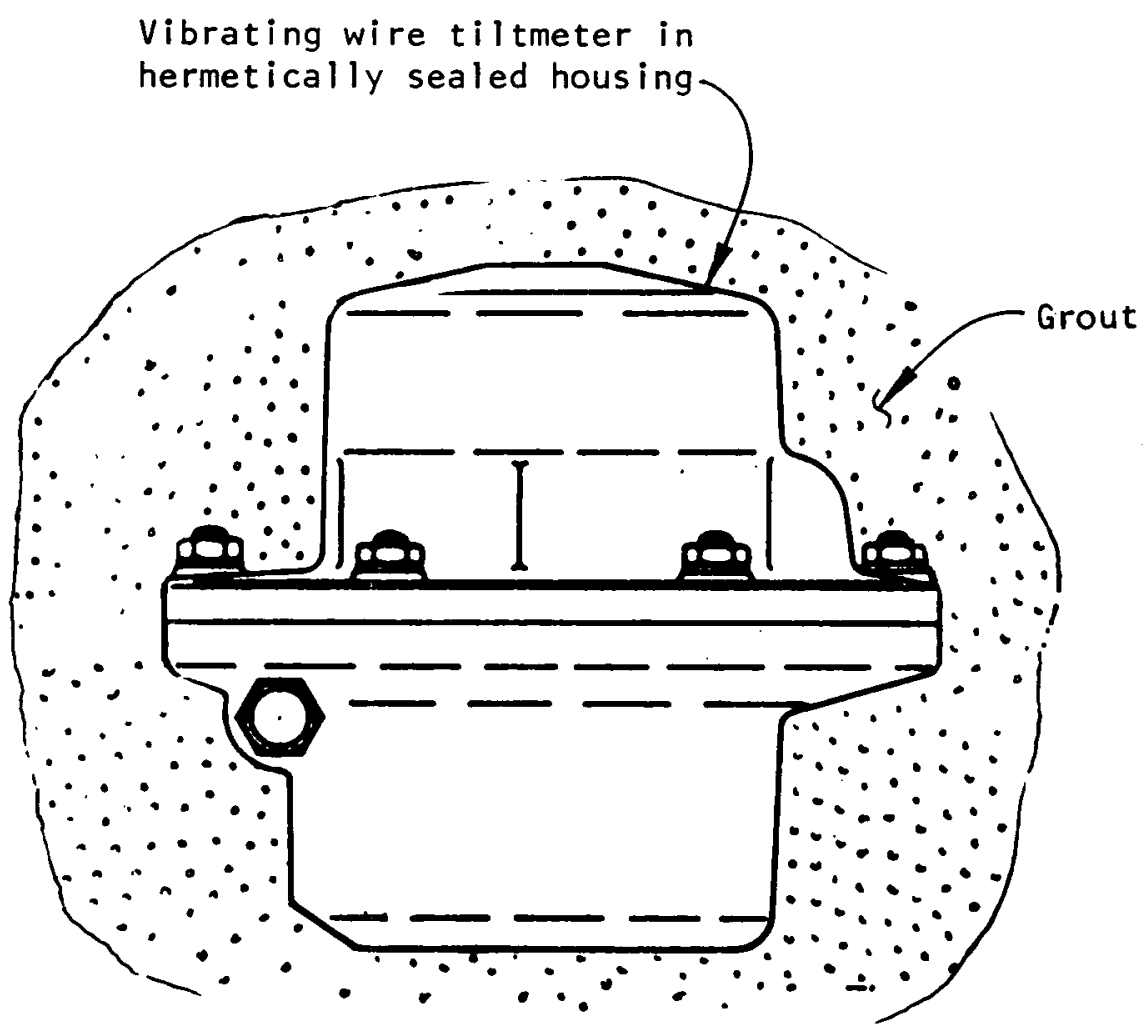

FIGURE D-5 - GROUTED-IN-PLACE TILTMETER (Maihak, 1977) 



FIGURE D-6 - LOCKED-IN-PLACE TILTMETERS (Maihak, 1977) 
Portable tiltmeters consist of a bench plate permanently fixed to a surface and a portable sensor (either mechanical or electrical).

Electrical sensors with a battery-powered readout are available as single units. Figures $D-7$ and $D-8$ are diagrams of mechanical and electrical portable tiltmeters, respectively.

The permanent bench plate can be made of either ceramic or stainless steel. The choice of material will depend on environmental conditions; corrosion of the plate may result in inaccurate readings. The plate can be either surface mounted or welded to a pipe that has been driven or drilled into the ground (see Figure D-9). It must be positioned such that the portable sensor can be consistantly aligned with a given set of grooves, notches, or pegs for a reading, and then turned $90^{\circ}$ and consistantly aligned again at the right angle position.

The range of various tiltmeters is dependent upon the type of sensor being used, while their accuracy is less dependent upon the type. The tiltmeter shown in Figures $D-5$ and $D-6$ has a range of 30 degrees and an accuracy of 10 seconds, while the tiltmeter in Figure D-8 has a range of 10 minutes and is accurate to 2 seconds, and the mechanical mode 1 shown in Figure $0-7$ has a range of 1 degree but is also accurate to 2 seconds.

Tilt at a point may not be representative of the subsidence profile because of local changes in geology and surface soils. Therefore, a certain redundancy in quantity of tilt data is appropriate to average out inevitable local anomalies. For use in special-purpose monitoring, bench plates should be set in a configuration consistent with the movement expected in the area being monitored. Periodic readings of slopes will enable determination of changes of slope at each bench plate location. Readings from a number of closely-spaced plate marks can be used to develop the trends of slope changes in an area, and may permit developing a map of isotilt contours for the area. 
PLAN VIEW OF LEVELLING

PLATE WITH COVER REMOVED



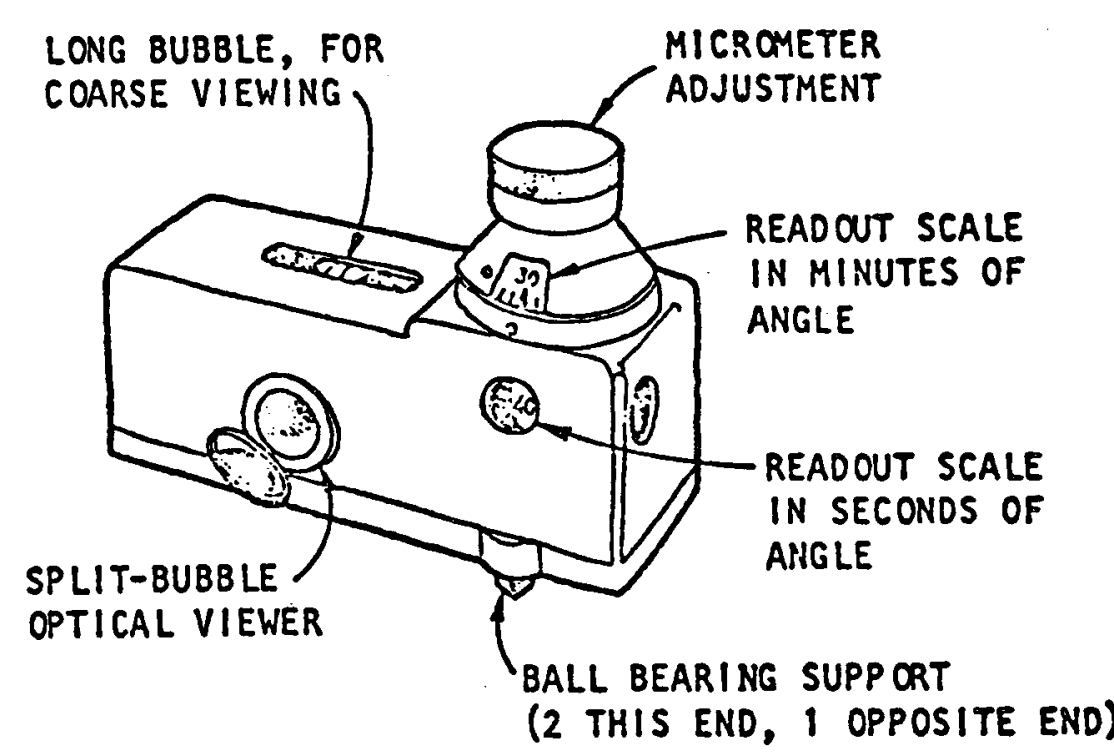

FIGURE D-7 - MECHANICAL SPIRIT LEVEL TILT METER AND LEVELLING PLATE

(from 0'Rourke et al, 1977) 


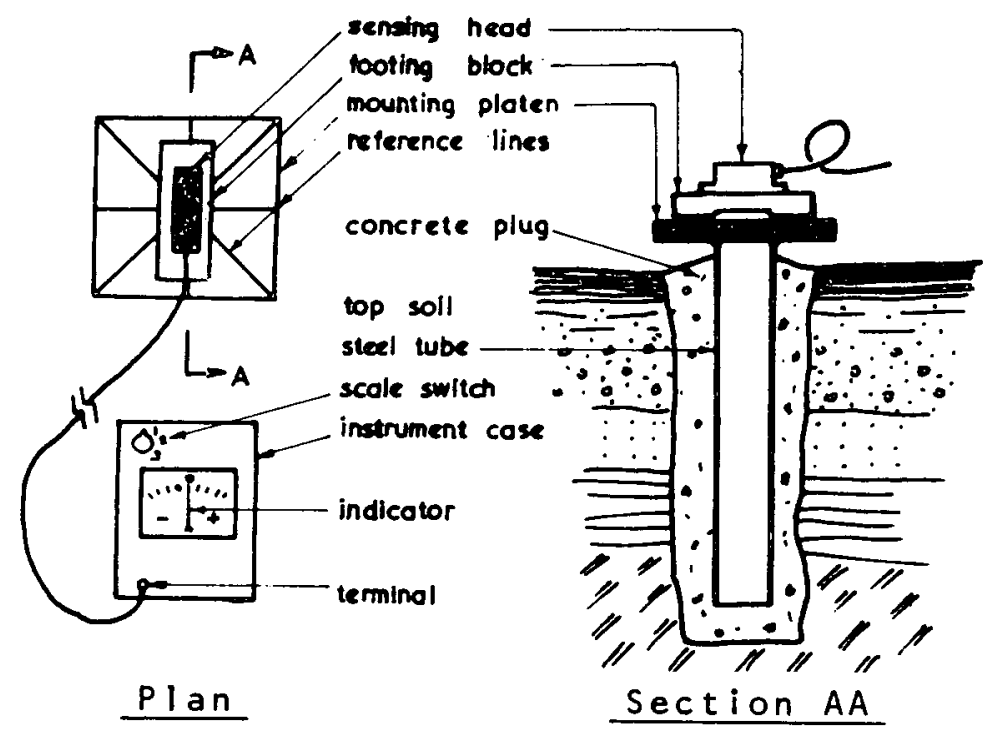
a) Field Set-up
b) Section through Field Station

METHOD OF MEASURING GROUND TILT WITH PORTABLE ELECTROLYTIC SPIRIT LEVEL (Whittaker \& Forrester, 1974)

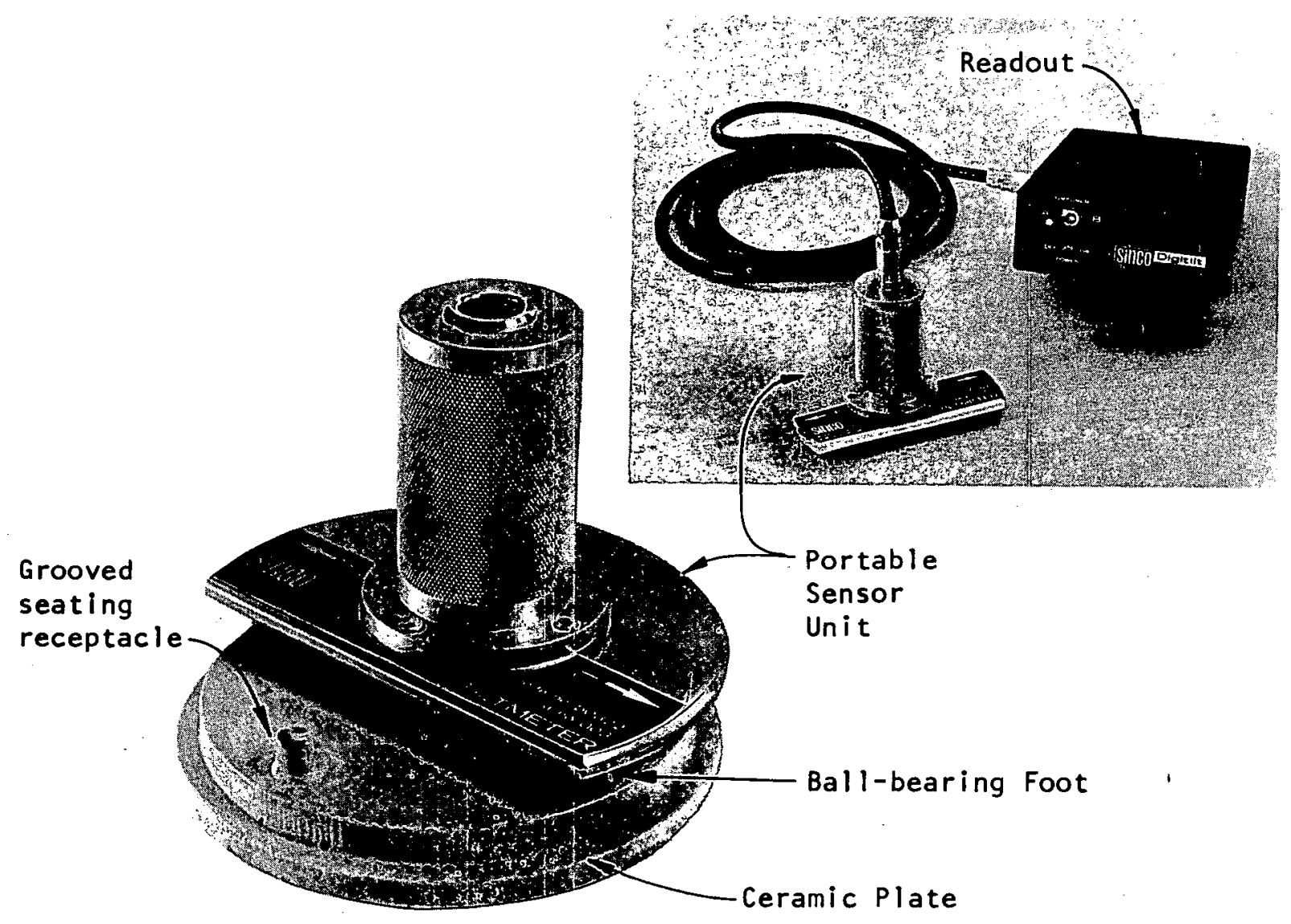

$\frac{\text { ELECTRONIC SENSOR IN READING POSITION ON CERAMIC TILT PLATE }}{(\text { SinCO, 1977) }}$
FIGURE D-8 -
E L E E C T R
T I L T M E T E R 


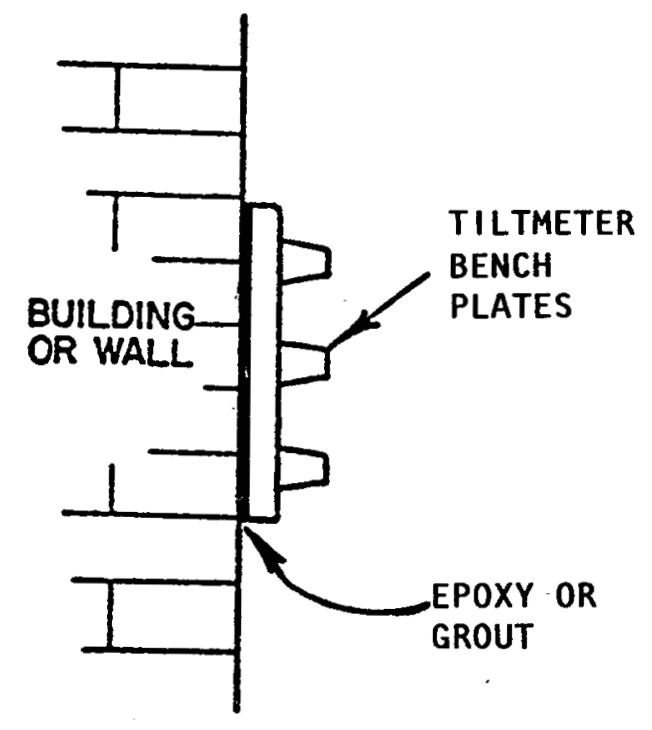

A - FIXED TO WALL OR VERTICAL ROCK OUTCROP

$\frac{1}{\text { के }}$

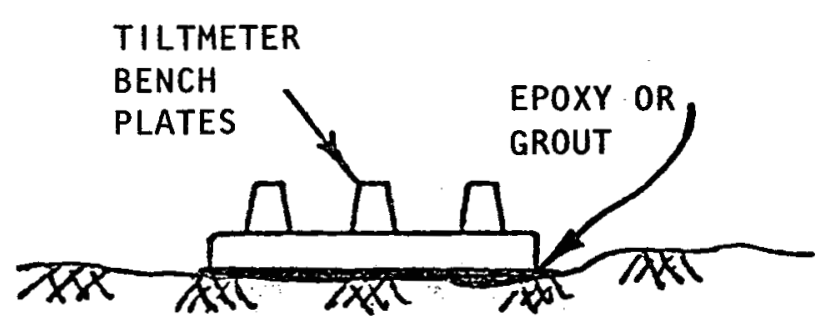

B - FIXED TO SOIL OR HORIZONTAL ROCK OUTCROP

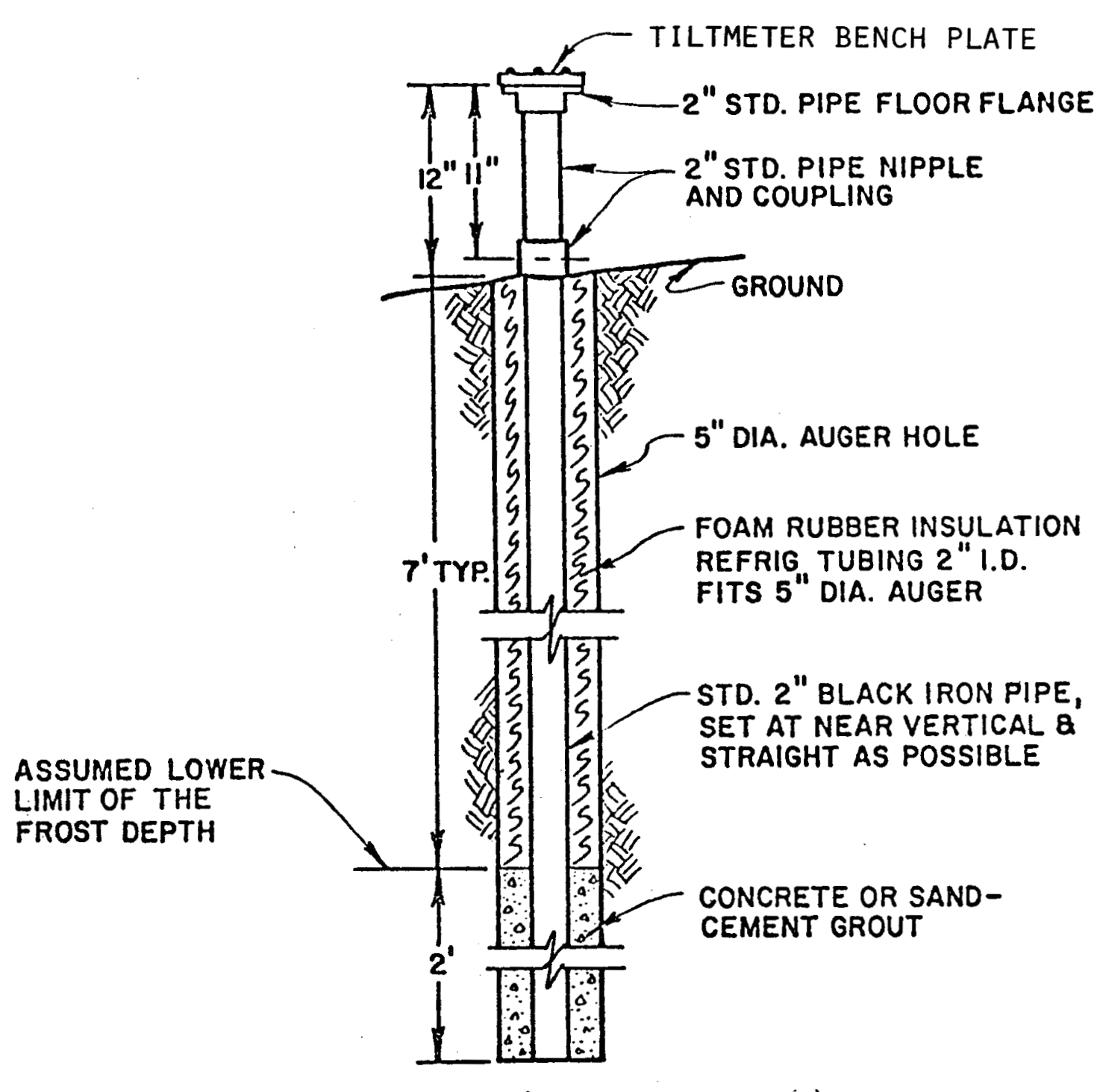

C - DRILLED INTO SOIL (ALSO CAN BE DRIVEN)

FIGURE D-9 - TYPICAL TILTMETER INSTALLATIONS (after Bomola, 1978) 
Monitoring the tilt of a large area with permanent tiltmeters would not be practical. The portable instruments give as good or better accuracy than permanent ones, and require only one sensor-readout apparatus to monitor as many bench plates as are needed to characterize the tilt in the area.

\section{3 BENCH MARKS}

Bench marks are permanent or semi-permanent physical marks whose elevation and horizontal placement are known, or, for surface monitoring purposes, whose elevation and horizontal placement are periodically redetermined. They usually consist of a bronze or brass cap, suitably inscribed for identification, and fixed in place by means such as grouting into rock or the foundation of a structure, casting into a concrete post in soil,

or fastening to the top of a pipe or rod driven into the ground. Professional survey firms usually will install bench marks in the course of performing survey services, and will have the background and experience to advise regarding suitable designs for an area.

Special bench mark designs may be required in certain environments. For example, where frost penetration is unusually deep or where there is a substantial layer of expansive soils, a special bench mark of the type described in Figure D-10 may be used. The design is based on the requirements of a cold environment as described by the National Geodetic Survey (Rappleye, 1948), the British Geotechnical Society (Builand \& Moore, 1973), and the United States Army (Sanger, 1969). (The 24 feet of pipe below the frost zone is considered to be an adequate anchor against the effects of freezing and thawing and is probably adequate to avoid any extraneous surficial distortions occurring in or around geothermal fields). The plastic grout should have a 7-day strength of about one-quarter the strength of the ground around it to ensure that the grout will not act as a local reinforcement. 




FIGURE D-10 - STABLE BENCH MARK FOR DEEP FROST PENETRATION AREAS 
Special bench mark designs may also be required by a corrosive environment. Geothermal steam and high-temperature water are characteristically high in certain dissolved chemicals. When the steam is released into the atmosphere (as at the Geysers in California) the chemicals are also released. In sufficient concentration, these chemicals can damage materials used for bench marks. The chemicals that do the most damage are hydrogen sulfide $\left(\mathrm{H}_{2} \mathrm{~S}\right)$ and carbon dioxide $\left(\mathrm{CO}_{2}\right)$. The bronze or brass disc is particularly susceptible to corrosion by $\mathrm{H}_{2} \mathrm{~S}$, therefore use of another metal may be warranted. Possible replacements are austentic stainless steel, titanium, and chromium plating (Marshall \& Braithwaite, 1973). In a moist, oxidizing environment $\mathrm{H}_{2} \mathrm{~S}$ is converted to sulfurous acid which will slowly disintegrate concrete. However, a more serious problem for concrete is $\mathrm{CO}_{2}$, which can cause permanent shrinkage, and when mixed with water to form carbonic acid, can slowly disintegrate it. To avoid damage to concrete, protective coatings such as epoxys, neoprenes, or vinyls are recommended (ACI Committee 515, 1966).

\section{D.4 INSTRUMENT RATINGS}

Table D-1 is a summary of the capabilities of instruments which have applications in surface monitoring of geothermal subsidence. Separate sections of this table describe surveying instruments, extensometers, tube profile devices, and tiltmeters. In general, surveying instruments are used in establishing the regional network and in establishing and monitoring the local network, although they would have applications in special monitoring also. Extensometers are applicable to monitoring of horizontal movements between relatively closely-spaced points, for example, in ground cracking, movements across fault lines, relative movements between points on a structure. Tube profile devices have applicability to monitoring of vertical movements between relatively closely-spaced points, primarily points which are inaccessible to other methods of measurement. Tiltmeters are used for point monitoring, and by means of a network of points, may be used to monitor areal movements.

The instruments included in Table D-1 were selected from a comprehensive list developed for the project cited in the table. This list was developed from quantitative data, qualitative experience, and judgements reported in the literature. The selections for use here were made on 
TABLE D-1 - IMSTRUMENT CAPABILITIES

(SUMmaRIzEd fROM "SUBSIDENCE MONITORING SYSTEMS FOR

Undermimed Areas" J. E. O'Rourke et aL, HCC, 1977)

\begin{tabular}{|c|c|c|c|c|c|c|c|}
\hline \multirow[b]{2}{*}{ Instranent } & \multirow[b]{2}{*}{ AVAILABILITY } & \multirow[b]{2}{*}{ 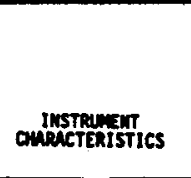 } & \multicolumn{2}{|c|}{$\begin{array}{l}\text { Data } \\
\text { coltection } \\
\text { chacter } \\
\text { ISTICS } \\
\end{array}$} & \multirow[b]{2}{*}{ Runere } & \multirow[b]{2}{*}{ accuracr } & \multirow[b]{2}{*}{  } \\
\hline & & & $\begin{array}{l}\text { RDPTE } \\
\text { OIRECT }\end{array}$ & $\begin{array}{l}\text { EmtER } \\
\text { supsio } \\
\text { EncE } \\
\text { Mes }\end{array}$ & & & \\
\hline $\begin{array}{l}\text { stol tipe } \\
\text { (structure and } \\
\text { surface strain, } \\
\text { surfice and } \\
\text { structure crack } \\
\text { novement) }\end{array}$ & $\begin{array}{l}\text { Torixin: } \\
\text { Chesterimen: } \\
\text { Kusffel } \\
\text { o Esser }\end{array}$ & $\begin{array}{l}\text { Porteble, ruges, } \\
\text { long life }\end{array}$ & Direct & Yes & $\begin{array}{l}\text { loort. } \\
\text { usually; } \\
\text { swallabie } \\
\text { in } 3 \text { to } \\
300 \text { it } \\
\text { lengths }\end{array}$ & $90.01 \mathrm{ft}$ & $\begin{array}{l}\text { Teperature; wind: } \\
\text { tension }\end{array}$ \\
\hline $\begin{array}{l}\text { Invar tape } \\
\text { (structure and } \\
\text { surface strain, } \\
\text { surface ind } \\
\text { structure crack } \\
\text { wovenent) }\end{array}$ & $\begin{array}{c}\text { Kauffel } \\
\text { I Esser }\end{array}$ & $\begin{array}{l}\text { Porteble, prone } \\
\text { to breaking }\end{array}$ & Otrect & res & $\begin{array}{l}50 \mathrm{ft} \\
100 \mathrm{ft}\end{array}$ & $20.005 \mathrm{ft}$ & Mind; tenston \\
\hline $\begin{array}{l}\text { Prec1sion level } \\
\text { (euteantic or } \\
\text { tilting with } \\
\text { eptical ulcro- } \\
\text { ter) with } \\
\text { fnvar rod } \\
\text { (structure and } \\
\text { surface settle- } \\
\text { int; with tape } \\
\text { or tepe extenso- } \\
\text { wter for ground } \\
\text { tilt) }\end{array}$ & $\begin{array}{l}\text { Jenopt1k; } \\
\text { Rern; } \\
\text { Mild; } \\
\text { Leitz; } \\
\text { Zeiss: }\end{array}$ & $\begin{array}{l}\text { Porteble, rugged. } \\
\text { long life }\end{array}$ & Direet & Yes. & $\begin{array}{l}\text { Maxima } \\
\text { chenge } \\
\text { in } \\
\text { elevation } \\
\text { between } \\
\text { slghts } \\
\text { opprox. } \\
\text { i3 ft; } \\
\text { sight } \\
\text { length } \\
\text { greater } \\
\text { then ift } \\
\text { and less } \\
\text { then } \\
150 \mathrm{ft}\end{array}$ & $\begin{array}{l}20.002 \mathrm{ft} \\
\text { to } 20.005 \\
\text { ft over } \\
\text { aile } \\
\text { efreult }\end{array}$ & $\begin{array}{l}\text { Wind; brifot } \\
\text { sunifigt }\end{array}$ \\
\hline 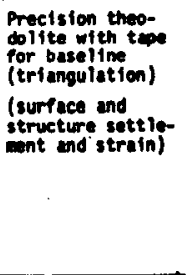 & $\begin{array}{l}\text { Kern; } \\
\text { Wild; } \\
\text { Jenoptik: } \\
\text { Leltz }\end{array}$ & As above & Direct & no & & $\begin{array}{l}\text { 1 sec } \\
\text { instrument } \\
\text { read to } 0.2 \\
\text { sec by } \\
\text { angle } \\
\text { repetition: } \\
1: 20,000 \text { to } \\
1: 50,000 ; \\
\text { best } \\
\text { positional } \\
\text { accurecy } \\
\pm 0.001 \text { in } \\
\pm 0.005 \mathrm{ft}\end{array}$ & $\begin{array}{l}\text { Temerature; wind; } \\
\text { vibratton; direct } \\
\text { sun; teporature } \\
\text { sensitivity } \\
\text { ainimal with } \\
\text { inver ;tope }\end{array}$ \\
\hline 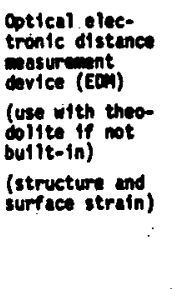 & $\begin{array}{l}\text { First } \\
\text { deviloperd } \\
\text { 1948; } \\
\text { hesi } \\
\text { Karn }\end{array}$ & $\begin{array}{l}\text { Porteble; retro- } \\
\text { reflectors wy } \\
\text { be portable or } \\
\text { fixed to } \\
\text { reforence polnt }\end{array}$ & Oirect & $\begin{array}{l}\text { res- } \\
\text { rod } \\
\text { onily }\end{array}$ & $\mathrm{ft}^{20,000}$ & 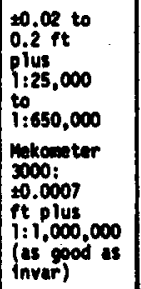 &  \\
\hline $\begin{array}{l}\text { Infrared en } \\
\text { (use with theo- } \\
\text { olite if not } \\
\text { ouitit-in) } \\
\text { (structure and } \\
\text { surfoce strand } \\
\text { ond settienent) }\end{array}$ & 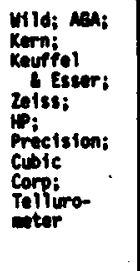 & As nowe & Direct & $\begin{array}{l}\text { Yos- } \\
\text { rod } \\
\operatorname{man} \\
\text { only }\end{array}$ & $\begin{array}{l}1000 \text { to } \\
16,000 \\
\text { fti } \\
\text { olnimini } \\
\text { i ft }\end{array}$ & $\begin{array}{l}\text { Typlcelly } \\
0.02 \mathrm{ft} \\
\text { pius } \\
1: 100,000 \\
\text { to } \\
\text { l: } 300,000 ; \\
\text { Telluro- } \\
\text { eter } \\
\text { in } 100 ; \\
0.002 \mathrm{ft} \\
\text { over } \\
300 \mathrm{ft}\end{array}$ & $\begin{array}{l}\text { Temarature and } \\
\text { prossures ieas } \\
\text { sensitive then } \\
\text { other Eow's; cen } \\
\text { use day or nitht } \\
\text { and in bright } \\
\text { sun }\end{array}$ \\
\hline 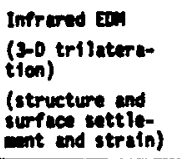 & As bove & As coove & Olrect & 100 & As above & As above & As above \\
\hline $\begin{array}{l}\text { Laser edn } \\
\text { (strueture and } \\
\text { surfece strain) }\end{array}$ & $\begin{array}{l}\text { Doweloped } \\
\text { late } \\
\text { ieso's; } \\
\text { ind }\end{array}$ & As above & DIrect & $\begin{array}{l}\text { res- } \\
\text { rad } \\
\text { monly }\end{array}$ & $\begin{array}{l}\operatorname{son}_{20,000} \text { to } \\
f t\end{array}$ & $\begin{array}{l}20.01 \text { to } \\
0.08 \mathrm{ft} \\
\text { and } \\
1: 1,000,000 \mathrm{i} \\
\pm 0.015 \\
\text { over } \\
\text { ig. }\end{array}$ & $\begin{array}{l}\text { Teporature and } \\
\text { pressure; ango: } \\
\text { dust; fogi afr } \\
\text { turbulence; } \\
\text { senstive to } \\
\text { vibration }\end{array}$ \\
\hline 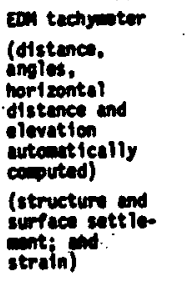 & 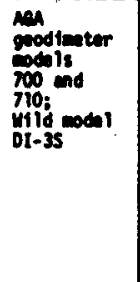 & Portable & 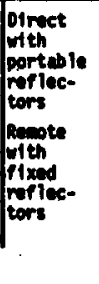 & $\begin{array}{l}\text { Yos- } \\
\text { rod } \\
\text { enly } \\
\text { only }\end{array}$ & $\begin{array}{l}1000 \text { to } \\
15,000 \\
p t\end{array}$ & $\begin{array}{l}.02 \mathrm{ft} \\
\text { plus } \\
1: 1,000,000 \\
\text { to } .02 \text { fe } \\
\text { plus } \\
5: 1,000,000\end{array}$ & $\begin{array}{l}\text { Temprature; } \\
\text { pressure; } \\
\text { vibration; } \\
\text { dust }\end{array}$ \\
\hline
\end{tabular}


Table D-1 (side 2)

\begin{tabular}{|c|c|c|c|c|c|}
\hline $\begin{array}{l}\text { CM IERATION } \\
\text { ANO } \\
\text { MINTEMANCE }\end{array}$ & $\begin{array}{l}\text { EASE/COST } \\
\text { OF } \\
\text { IMSTRLLATIOW }\end{array}$ & $\begin{array}{l}\text { EASE/COST } \\
\text { OF } \\
\text { OPERATIOK }\end{array}$ & $\begin{array}{l}\text { PONER } \\
\text { REQUIREIENTS }\end{array}$ & $\begin{array}{c}\text { EASE/COST } \\
\text { Of } \\
\text { OATA REOUCTION }\end{array}$ & $\begin{array}{c}\text { COST } \\
\text { of } \\
\text { InSTRUAENT }\end{array}$ \\
\hline $\begin{array}{l}\text { Perlodically } \\
\text { clean, ofl, and } \\
\text { calbrate } \\
\text { against } \\
\text { standard tepe }\end{array}$ & $\begin{array}{l}\text { Install } \\
\text { reference } \\
\text { points }\end{array}$ & $\begin{array}{l}2 \text { tepemen plus } \\
1 \text { mon to set } \\
\text { stakes; use } \\
\text { with tenston- } \\
\text { ing device. } \\
\text { toping pins, } \\
\text { plumboob }\end{array}$ & Mone & Sinole & $\begin{array}{l}100 \mathrm{ft}: \$ 30 \mathrm{to} \\
\$ 300\end{array}$ \\
\hline $\begin{array}{l}\text { Clean } \\
\text { pertodically }\end{array}$ & As above & $\begin{array}{l}2 \text { tepenen; use } \\
\text { with tension } \\
\text { fr woss and } \\
\text { wolghts; for } \\
\text { high accuracy } \\
\text { repeat readings } \\
\text { with } 3 \text { tapes }\end{array}$ & None & Simple & $\begin{array}{l}100 \mathrm{ft}: \$ 300 \\
150 \mathrm{ft}: \$ 400\end{array}$ \\
\hline $\begin{array}{l}\text { Check } \\
\text { te lescope } \\
\text { ilignent } \\
\text { annually }\end{array}$ & $\begin{array}{l}\text { Install } \\
\text { reference } \\
\text { points and } \\
\text { bench marks }\end{array}$ & $\begin{array}{l}1 \text { instrument } \\
\text { man; } 1 \text { rod man }\end{array}$ & None & $\begin{array}{l}\text { Sim le; need } \\
1 \text { engineer; may } \\
\text { use computer } \\
\text { to reduce large } \\
\text { volume of dati }\end{array}$ & $\begin{array}{l}\text { Leve1: } \$ 850 \\
\text { to } \$ 1500: \\
\text {.rod: } \$ 700\end{array}$ \\
\hline As above & $\begin{array}{l}\text { Install } \\
\text { reference } \\
\text { polnts and } \\
3 \text { Instrument } \\
\text { stations }\end{array}$ & $\begin{array}{l}1 \text { surveyor: } \\
\text { and I rod man } \\
\text { if targets not } \\
\text { f1 xed; } 2 \text { men } \\
\text { needed for } \\
\text { taping of } \\
\text { beselfines } \\
\text { between } \\
\text { Instrument } \\
\text { piers }\end{array}$ & Mone & $\begin{array}{l}\text { As above; } \\
\text { computer } \\
\text { programs } \\
\text { readily } \\
\text { avallable }\end{array}$ & $\begin{array}{l}\text { Prectstion } \\
\text { Theodoltte: } \\
\$ 3000 \text { to } \\
\$ 9000\end{array}$ \\
\hline $\begin{array}{l}\text { Collorate } \\
\text { aguinst so } \\
\text { eter invar } \\
\text { tepe every } \\
\text { two years }\end{array}$ & $\begin{array}{l}\text { Instell } \\
\text { reference } \\
\text { points }\end{array}$ & $\begin{array}{l}\text { I surveyor } \\
\text { plus I Yaborer } \\
\text { if retro- } \\
\text { roriectors } \\
\text { portable or } \\
\text { adjus table: } \\
\text { lomer cost par } \\
\text { afle of trav- } \\
\text { erse than } \\
\text { conventional } \\
\text { wothods }\end{array}$ & $\begin{array}{l}\text { Rechargeable } \\
\text { battery for } \\
\text { I day's work }\end{array}$ & $\begin{array}{l}\text { Oistence } \\
\text { ususily } \\
\text { autoantic; } \\
\text { ifew provide } \\
\text { only phase } \\
\text { shift ind } \\
\text { surveyor wist } \\
\text { convert to } \\
\text { distance }\end{array}$ & $\begin{array}{l}\text { Typtcal ED: } \\
\text { Mekometer } 3000 \text { : } \\
\$ 34,000 \text {; } \\
\text { refiectors: } \\
\text { \$0.50 to \$110 }\end{array}$ \\
\hline As above & As above & As above & $\begin{array}{l}\text { Rechargable } \\
\text { ottery for } \\
1 \text { cay's work }\end{array}$ & $\begin{array}{l}\text { Oistance usually } \\
\text { automatic: most } \\
\text { have eutomatic } \\
\text { correction for } \\
\text { tempertiure end } \\
\text { pressure }\end{array}$ & 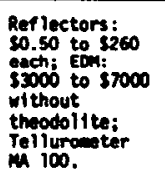 \\
\hline As above & $\begin{array}{l}\text { Install } \\
\text { reference } \\
\text { points and } \\
\text { Instrument } \\
\text { stations }\end{array}$ & 1 surveyor & As abow & $\begin{array}{l}\text { As above; } \\
\text { reduce } \\
\text { distances to } \\
\text { EOH to } \\
\text { coordinates }\end{array}$ & As ebove \\
\hline As above & As sbove & $\begin{array}{l}1 \text { surveyor } \\
\text { and I roo } \\
\text { and }\end{array}$ & $\begin{array}{l}\text { Lowr power } \\
\text { consuption } \\
\text { then other } \\
\text { Eon's; } \\
\text { rechargable } \\
\text { bettery' for } \\
1 \text { day's wort }\end{array}$ & $\begin{array}{l}\text { Distance auto } \\
\text { antic }\end{array}$ & . \\
\hline As above & $\begin{array}{l}\text { Install } \\
\text { reference } \\
\text { points; } \\
\text { 1nstali } \\
\text { Instrument } \\
\text { stat ions } \\
\text { If used }\end{array}$ & $\begin{array}{l}\text { I surveyor } \\
\text { and i rod } \\
\text { min, if } \\
\text { targets } \\
\text { not fixed }\end{array}$ & $\begin{array}{l}\text { Rechargable } \\
\text { pattery. for } \\
\text { i duy's } \\
\text { operetion }\end{array}$ & 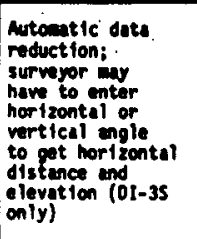 & $\begin{array}{l}\$ 18,000 ; \\
\$ 10, \infty 000 \text { (01-35 } \\
\text { ut thout } \\
\text { theodolite); } \\
\text { ref lectors } \\
\$ 0.50 \text { to } \\
\$ 260 \text { each }\end{array}$ \\
\hline
\end{tabular}




\begin{tabular}{|c|c|c|c|c|c|c|c|}
\hline \multirow[b]{2}{*}{ INSTRUMENT } & \multirow[b]{2}{*}{ AVAILABILITY } & \multirow[b]{2}{*}{$\begin{array}{c}\text { INSTRUMENT } \\
\text { CHARACTERISTICS } \\
\end{array}$} & \multicolumn{2}{|c|}{$\begin{array}{l}\text { DATA } \\
\text { COLLECTION } \\
\text { CHARACTER- } \\
\text { ISTICS }\end{array}$} & \multirow[b]{2}{*}{ RANGE } & \multirow[b]{2}{*}{ ACCURACY } & \multirow[b]{2}{*}{$\begin{array}{c}\text { SENSITIVITY } \\
\text { TO } \\
\text { ENVIRONMENT } \\
\end{array}$} \\
\hline & & & $\begin{array}{l}\text { REMTE } \\
\text { OR } \\
\text { DIRECT } \\
\end{array}$ & $\begin{array}{c}\text { ENTER } \\
\text { SUBSID- } \\
\text { ENCE } \\
\text { AREA } \\
\end{array}$ & & & \\
\hline $\begin{array}{l}\text { Rod extensometer } \\
\text { with dial gauge } \\
\text { (ground or } \\
\text { structure strain } \\
\text { and crack } \\
\text { movement) }\end{array}$ & $\begin{array}{l}\text { Terrametrics; } \\
\text { Structural } \\
\text { Behavior } \\
\text { Engineering } \\
\text { Laboratories } \\
\text { or user } \\
\text { fabricated; } \\
\text { Nason (197i) }\end{array}$ & $\begin{array}{l}\text { Permanent for } \\
\text { monitoring } \\
\text { period; } \\
\text { recoverable } \\
\text { rugged and } \\
\text { dependable }\end{array}$ & Direct & Yes & $\begin{array}{l}\text { Displace- } \\
\text { ment } \\
\text { ranges to } \\
1.0 \text { in., } \\
\text { resettable } \\
\text { gauge } \\
\text { length } \\
10 \text { in. to } \\
20 \text { in.; if } \\
\text { user fab- } \\
\text { ricated } \\
\text { gauge } \\
\text { length may } \\
\text { be } 10 \text { feet }\end{array}$ & $\begin{array}{l}\text { Sensitivity } \\
\text { of } 0.0001 \\
\text { in. }\end{array}$ & $\begin{array}{l}\text { Susceptible to } \\
\text { vandalism unless } \\
\text { protected; } \\
\text { sensitive to } \\
\text { temperature }\end{array}$ \\
\hline $\begin{array}{l}\text { Steel tape } \\
\text { extensometer } \\
\text { (ground or } \\
\text { structure strain, } \\
\text { convergence) }\end{array}$ & $\begin{array}{l}\text { Sinco; } \\
\text { Irad; } \\
\text { Terrametrics; } \\
\text { Interfelis; } \\
\text { Solltest }\end{array}$ & $\begin{array}{c}\text { Portable; } \\
\text { dependable } \\
\qquad:\end{array}$ & Direct & Yes & $\begin{array}{l}\text { Disp lace- } \\
\text { ment ranges } \\
\text { of } 0.01 \text { in. } \\
\text { to } 100 \mathrm{ft} \text {; } \\
\text { gauge } \\
\text { length } 2 \mathrm{ft} \\
\text { to } 100 \mathrm{ft}\end{array}$ & $\pm 0.01 \mathrm{in}$. & $\begin{array}{l}\text { Reference points } \\
\text { susceptible to } \\
\text { damage; sensitive } \\
\text { to temperature }\end{array}$ \\
\hline $\begin{array}{l}\text { Invar wire } \\
\text { extensometer. } \\
\text { (ground or } \\
\text { structure strain, } \\
\text { convergence) }\end{array}$ & $\begin{array}{l}\text { Telemac; } \\
\text { Kern }\end{array}$ & Portable & Remote & Yes & $\begin{array}{l}\text { Displace- } \\
\text { ment ranges } \\
\text { of } 2.5 \mathrm{ln} . \\
\text { to } 4.0 \mathrm{in} . \mathrm{i} \\
\text { gauge } \\
\text { length of } \\
3 \mathrm{ft} \text { to } \\
150 \mathrm{ft}\end{array}$ & $\begin{array}{l} \pm 0.0008 \\
\text { in. to } \\
0.002 \text { in. }\end{array}$ & $\begin{array}{l}\text { Reference points } \\
\text { susceptible to } \\
\text { damage; } \\
\text { insignificant } \\
\text { temperature } \\
\text { effects }\end{array}$ \\
\hline $\begin{array}{l}\text { Rod extensiometer } \\
\text { with LVDT } \\
\text { (ground and } \\
\text { structure strain } \\
\text { and crack } \\
\text { movement) }\end{array}$ & $\begin{array}{l}\text { User } \\
\text { fabricated; } \\
\text { Kennedy } \\
(1971)\end{array}$ & $\begin{array}{l}\text { Permanent for } \\
\text { monitoring } \\
\text { pertod; may be } \\
\text { recoverable; } \\
\text { suitable for } \\
\text { long-term } \\
\text { monitoring }\end{array}$ & Remote & No & $\begin{array}{l}\text { Displace- } \\
\text { ment ranges } \\
\text { of } 0.10 \mathrm{in} . \\
\text { to } 6 \mathrm{in.;} \\
\text { gauge } \\
\text { length } \\
5 \mathrm{ft} \text { to } \\
10 \mathrm{ft}\end{array}$ & $\begin{array}{l} \pm 0.001 \\
\text { in. pos- } \\
\text { sibie: } \\
\text { infinite } \\
\text { resolution }\end{array}$ & $\begin{array}{l}\text { Electronics not } \\
\text { very sensitive to } \\
\text { vibration or } \\
\text { temperature, but } \\
\text { susceptible to } \\
\text { changes in line } \\
\text { resistance, cable } \\
\text { length, or input } \\
\text { voltage variance; } \\
\text { may be subject to } \\
\text { corrosion, } \\
\text { vandalism and } \\
\text { sensitive to } \\
\text { temperature }\end{array}$ \\
\hline $\begin{array}{l}\text { Rod extensoneter } \\
\text { wt th machinist's } \\
\text { scale } \\
\text { (ground and } \\
\text { structure strain } \\
\text { and crack } \\
\text { movement) }\end{array}$ & $\begin{array}{l}\text { User } \\
\text { fabricated; } \\
\text { Utter and } \\
\text { Tescn } \\
(1965)\end{array}$ & $\begin{array}{l}\text { May be } \\
\text { permanent for } \\
\text { monitoring } \\
\text { period or may } \\
\text { be portable }\end{array}$ & Direct & Yes & $\begin{array}{l}\text { Oisplace- } \\
\text { ment ranges } \\
\text { of } 0.1 \mathrm{in} . \\
\text { to } 10 \mathrm{ft} \text {; } \\
\text { typ ical } \\
\text { gauge } \\
\text { length } \\
3 \mathrm{ft} \text { to } \\
10 \mathrm{ft}\end{array}$ & $\begin{array}{l}\text { Sensitivity } \\
\text { of } 0.01 \text { in. }\end{array}$ & $\begin{array}{l}\text { Susceptible to } \\
\text { corrosion, } \\
\text { vandalism and } \\
\text { sensitive to } \\
\text { temperature }\end{array}$ \\
\hline $\begin{array}{l}\text { Rod extensometer } \\
\text { with micrometer } \\
\text { (surface or } \\
\text { structure strains } \\
\text { and crack } \\
\text { movement) }\end{array}$ & $\begin{array}{l}\text { Micro- } \\
\text { precision } \\
\text { Engineering } \\
\text { Livermore, } \\
\text { CA } \\
\text { Burland and } \\
\text { Moore, } \\
1973\end{array}$ & Portable & Direct & Yes. & $\begin{array}{l}\text { Displace- } \\
\text { ment ranges } \\
\text { of } 0.001 \text { in } \\
\text { to } 3.0 \text { in.; } \\
\text { typical } \\
\text { gauge } \\
\text { length } \\
10 \mathrm{ft}\end{array}$ & $\begin{array}{l} \pm 0.005 \\
\text { in.; } \\
\text { sensitivity } \\
\text { of } 0.0004 \\
\text { in. }\end{array}$ & $\begin{array}{l}\text { Reference points } \\
\text { suscept ible to } \\
\text { damage; sensitive } \\
\text { to temperature } \\
\text { unless invar }\end{array}$ \\
\hline
\end{tabular}


Table D-1 (side 2)

\begin{tabular}{|c|c|c|c|c|c|}
\hline $\begin{array}{c}\text { CALIBRATION } \\
\text { AND } \\
\text { MAINTENANCE }\end{array}$ & $\begin{array}{l}\text { EASE / COST } \\
\text { OF } \\
\text { INSTALLATION }\end{array}$ & $\begin{array}{c}\text { EASE/COST } \\
\text { OF } \\
\text { OPERATION }\end{array}$ & $\begin{array}{c}\text { POWER } \\
\text { REQUIREMENTS }\end{array}$ & $\begin{array}{c}\text { EASE / COST } \\
\text { OF } \\
\text { DATA REDUCTION }\end{array}$ & $\begin{array}{c}\text { COST } \\
\text { OF } \\
\text { INSTRUMENT } \\
\end{array}$ \\
\hline $\begin{array}{l}\text { Calibrate with } \\
\text { standard } \\
\text { reference bar; } \\
\text { easy to replace }\end{array}$ & $\begin{array}{l}\text { Embed reference } \\
\text { points in soll, } \\
\text { rock or } \\
\text { structure and } \\
\text { attach bar; } \\
\text { provide } \\
\text { protection for } \\
\text { instrument }\end{array}$ & $\begin{array}{l}\text { Simple; one } \\
\text { person to } \\
\text { read; can use } \\
\text { camera } \\
\text { recorder and } \\
\text { replace film } \\
\text { periodically }\end{array}$ & $\begin{array}{l}\text { Battery for } \\
\text { canera }\end{array}$ & $\begin{array}{l}\text { Convert dial } \\
\text { readings to } \\
\text { displacement; } \\
\text { temperature } \\
\text { correction }\end{array}$ & $\$ 100$ to $\$ 800$ \\
\hline $\begin{array}{l}\text { Problems with } \\
\text { tape breaking; } \\
\text { calibrate with } \\
\text { standard } \\
\text { reference bar; } \\
\text { ofl period- } \\
\text { ically and } \\
\text { check } \\
\text { tensioning } \\
\text { device }\end{array}$ & $\begin{array}{l}\text { Embed } \\
\text { reference } \\
\text { points in } \\
\text { soll, rock } \\
\text { or structure }\end{array}$ & $\begin{array}{l}\text { Simple; one } \\
\text { or two } \\
\text { people to } \\
\text { attach } \\
\text { extensometer } \\
\text { to reference } \\
\text { points, apply } \\
\text { tension and } \\
\text { read; two } \\
\text { people need } \\
\text { two hours } \\
\text { for is } \\
\text { readings }\end{array}$ & None & $\begin{array}{l}\text { Direct readout } \\
\text { of distance } \\
\text { makes data } \\
\text { reduction } \\
\text { simple; } \\
\text { temperature } \\
\text { corrections }\end{array}$ & $\$ 500$ to $\$ 1500$ \\
\hline $\begin{array}{l}\text { Calibrate with } \\
\text { standard } \\
\text { reference bar; } \\
\text { clean } \\
\text { periodically } \\
\text { and check } \\
\text { tensioning } \\
\text { device as well } \\
\text { as zero drift } \\
\text { of readout }\end{array}$ & As above & As above & 12 VDC & $\begin{array}{l}\text { Digital } \\
\text { readout of } \\
\text { distance } \\
\text { makes data } \\
\text { reduction } \\
\text { simple }\end{array}$ & $\$ 4800$ \\
\hline $\begin{array}{l}\text { Check for zero } \\
\text { drift; easy to } \\
\text { replace; } \\
\text { calibrate with } \\
\text { standard } \\
\text { reference bar }\end{array}$ & $\begin{array}{l}\text { Embed } \\
\text { reference } \\
\text { points in } \\
\text { soil, rock } \\
\text { or structure, } \\
\text { and attach } \\
\text { bar; provide } \\
\text { protection } \\
\text { for } \\
\text { instrument; } \\
\text { establish } \\
\text { zero reading; } \\
\text { enclose in } \\
\text { telescoping. } \\
\text { casing for } \\
\text { monitoring } \\
\text { convergence }\end{array}$ & $\begin{array}{l}\text { Simple, one } \\
\text { person to } \\
\text { take reading }\end{array}$ & None & $\begin{array}{l}\text { Direct } \\
\text { reading of } \\
\text { distance } \\
\text { makes data } \\
\text { reduction } \\
\text { simple; } \\
\text { apply. } \\
\text { temperature } \\
\text { correction }\end{array}$ & $\begin{array}{l}\text { LVDT \$200; } \\
\text { transducer } \\
\text { amplif ier } \\
\text { and } \\
\text { recorder } \\
\text { readout } \\
5800 ; \\
\text { cable } \\
\$ 14 / 20 \mathrm{ft}\end{array}$ \\
\hline $\begin{array}{l}\text { Clean } \\
\text { perfodically, } \\
\text { calibrate } \\
\text { with } \\
\text { standard. } \\
\text { reference } \\
\text { bar: easy } \\
\text { to repair }\end{array}$ & $\begin{array}{l}\text { Embed reference } \\
\text { points in soil, } \\
\text { rock or } \\
\text { structure; } \\
\text { provide } \\
\text { protection for } \\
\text { instrument }\end{array}$ & $\begin{array}{l}\text { Simple: one } \\
\text { person to } \\
\text { take reading }\end{array}$ & Mone & As above. & $\begin{array}{l}\text { Materials } \\
\text { and labor } \\
\$ 500\end{array}$ \\
\hline $\begin{array}{l}\text { Clean } \\
\text { perlodically; } \\
\text { calibrate } \\
\text { with } \\
\text { standard } \\
\text { reference } \\
\text { bar; easy } \\
\text { to repair }\end{array}$ & $\begin{array}{l}\text { Embed reference } \\
\text { points in soll, } \\
\text { rock, or } \\
\text { structure }\end{array}$ & $\begin{array}{l}\text { One or two } \\
\text { people to move } \\
\text { bar, adjust } \\
\text { micrometer } \\
\text { and take } \\
\text { reading }\end{array}$ & $\begin{array}{l}\text { Penlight } \\
\text { battery }\end{array}$ & $\begin{array}{l}\text { Direct readout } \\
\text { of distance } \\
\text { makes data } \\
\text { reduction } \\
\text { simple, } \\
\text { temperature } \\
\text { correction }\end{array}$ & $\begin{array}{l}\text { Materials } \\
\text { and labor } \\
\$ 600\end{array}$ \\
\hline
\end{tabular}




\begin{tabular}{|c|c|c|c|c|c|c|c|}
\hline INSTRUMENT & AVAILABILITY & $\begin{array}{l}\text { INSTRLWENT } \\
\text { CHARACTER ISTICS }\end{array}$ & 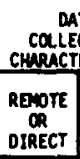 & $\begin{array}{l}\text { TA } \\
\text { CTION } \\
\text { ERISIICS } \\
\text { ENTER } \\
\text { SUBSID- } \\
\text { EMCE } \\
\text { AREA } \\
\text { AREA }\end{array}$ & RAMGE & ACCuRACY. & $\begin{array}{l}\text { SEWSIITIVITY } \\
\text { ENT } \\
\text { ENTRONEEMT }\end{array}$ \\
\hline 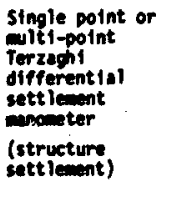 & $\begin{array}{l}\text { Serata: } \\
\text { Galitieo }\end{array}$ & 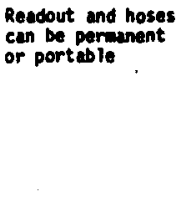 & Direct & Yes & $\begin{array}{l}\text { wp to } 50 \\
\text { ft of } \\
\text { settlement; } \\
\text { distances } \\
\text { p to } 1000 \\
\text { ft between } \\
\text { reference } \\
\text { points }\end{array}$ & $\pm 0.25 \mathrm{in}$. &  \\
\hline $\begin{array}{l}\text { Singie point } \\
\text { siple hose } \\
\text { manceater } \\
\text { (structure or } \\
\text { surfuce } \\
\text { settifent) }\end{array}$ & $\begin{array}{l}\text { So11 und } \\
\text { rock } \\
\text { instrumen- } \\
\text { tation; } \\
\text { also user } \\
\text { fubrcated; } \\
\text { ounncliliff } \\
\text { (1971) }\end{array}$ & $\begin{array}{l}\text { Permanent for } \\
\text { ponttoring } \\
\text { pertod; may be } \\
\text { recoverable }\end{array}$ & Direct & $\begin{array}{c}\text { Mo. } \\
\text { if } \\
\text { hose } \\
\text { is } \\
\text { long } \\
\text { enough }\end{array}$ & $\begin{array}{l}\text { Ip to } 20 \mathrm{ft} \\
\text { of settle- } \\
\text { ment }\end{array}$ & $\pm 0.50 \mathrm{in}$. & As above \\
\hline 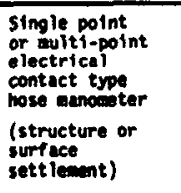 & $\begin{array}{l}\text { Soll and Rock } \\
\text { instrumeno- } \\
\text { tat lon; Soil } \\
\text { instruments }\end{array}$ & As above & Oirect & $\begin{array}{l}\text { As } \\
\text { above }\end{array}$ & $\begin{array}{l}\text { Wo to } 3 \mathrm{ft} \\
\text { of settle- } \\
\text { ment }\end{array}$ & $\pm 0.10 \mathrm{ln}$ & $\begin{array}{l}\text { As above; problems } \\
\text { with esectrontes } \\
\text { ikely: marcury is } \\
\text { used in freezing } \\
\text { temperatures }\end{array}$ \\
\hline $\begin{array}{l}\text { Single point } \\
\text { overf low type } \\
\text { mencemter } \\
\text { (structure or } \\
\text { surf face } \\
\text { settiement) }\end{array}$ & $\begin{array}{l}\text { Teleanc: } \\
\text { Sot1 } \\
\text { Instruments: } \\
\text { Galirieo }\end{array}$ & As above & Direct & $\begin{array}{c}\text { As } \\
\text { woove }\end{array}$ & $\begin{array}{l}\text { Lp to } 3 \mathrm{ft} \\
\text { of sett le- } \\
\text { ment }\end{array}$ & $\$ 0.20 \mathrm{in}$. & 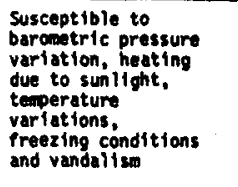 \\
\hline  & Telemec & $\begin{array}{l}\text { Permenent for } \\
\text { monitoring } \\
\text { pertod; } \\
\text { recoverable }\end{array}$ & Direct & $\begin{array}{c}\text { As } \\
\text { above }\end{array}$ & $\begin{array}{l}\text { Lp to } 10 \mathrm{ft} \\
\text { of settle- } \\
\text { ment }\end{array}$ & $20.30 \mathrm{ln}$ & As above \\
\hline $\begin{array}{l}\text { Full profile } \\
\text { a1r balloon } \\
\text { in liquid filled } \\
\text { tube settlement } \\
\text { device } \\
\text { (structure or } \\
\text { surfece } \\
\text { settlement) }\end{array}$ & $\begin{array}{l}\text { Soil } \\
\text { Instruments }\end{array}$ & $\begin{array}{l}\text { Probe and } \\
\text { readout are } \\
\text { portable }\end{array}$ & Direct & $\begin{array}{c}\text { As } \\
\text { ebove }\end{array}$ & $\begin{array}{l}\text { up to } 10 \mathrm{ft} \\
\text { of sett le- } \\
\text { ment }\end{array}$ & $\pm 0.60 \mathrm{in}$. &  \\
\hline $\begin{array}{l}\text { Full proftle } \\
\text { two liquid } \\
\text { pressure bal ance } \\
\text { monometer } \\
\text { (structure or } \\
\text { surface } \\
\text { sett lement) }\end{array}$ & $\begin{array}{l}\text { User } \\
\text { fabricated; } \\
\text { of Rourte } \\
\text { (1977) }\end{array}$ & $\begin{array}{l}\text { Peraanent for } \\
\text { Ponitorting } \\
\text { pertod; may be } \\
\text { precover able }\end{array}$ & $\begin{array}{l}\text { Direct } \\
\text { or } \\
\text { Remote }\end{array}$ & $\begin{array}{l}\text { As } \\
\text { above }\end{array}$ & $\begin{array}{l}\text { up to } 20 \mathrm{ft} \\
\text { of settle- } \\
\text { ment }\end{array}$ & $\pm 0.25 \mathrm{in}$. & As above \\
\hline $\begin{array}{l}\text { Ppi with fixed } \\
\text { electrolytic } \\
\text { level sensors } \\
\text { (surface } \\
\text { settient) }\end{array}$ & $\begin{array}{l}\text { User } \\
\text { fabricated; } \\
\text { Cooke and } \\
\text { Price } \\
(1973)\end{array}$ & $\begin{array}{l}\text { Peraunent for } \\
\text { penitoring } \\
\text { period; } \\
\text { recoverto le }\end{array}$ & Renoto & no & $\begin{array}{l}30 \text { minutes: } \\
\text { can be } \\
\text { mechlcantcally } \\
\text { extended to } \\
6 \text { degreas } \\
\text { doun, } 3 \\
\text { degrees up }\end{array}$ & 3 min. & $\begin{array}{l}\text { Sensitive to molsture, } \\
\text { changes in ilne } \\
\text { resistsance and cable } \\
\text { length; teaperature } \\
\text { does not affect } \\
\text { calibration, but } \\
\text { zero reading is } \\
\text { sensitive to } \\
\text { temperature } \\
\text { verlation and twist } \\
\text { of cosing }\end{array}$ \\
\hline
\end{tabular}


Table D-1 (side 2)

\begin{tabular}{|c|c|c|c|c|c|}
\hline $\begin{array}{l}\text { CNLIBRATION } \\
\text { AMO } \\
\text { MIITEMMCE }\end{array}$ & $\begin{array}{l}\text { EASE/COST } \\
\text { Of } \\
\text { INSTALLATION }\end{array}$ & $\begin{array}{l}\text { EASE/COST } \\
\text { OPR } \\
\text { OPRATION }\end{array}$ & $\begin{array}{c}\text { POUER } \\
\text { REQUIREMENTS }\end{array}$ & $\begin{array}{c}\text { EASE/COST } \\
\text { OF } \\
\text { OATA REDUCTION }\end{array}$ & $\begin{array}{c}\text { COST } \\
\text { of } \\
\text { IMSTRLMENT } \\
\end{array}$ \\
\hline $\begin{array}{l}\text { Hoses must be } \\
\text { free of air } \\
\text { bubbles, dirt. } \\
\text { algae, irttie } \\
\text { difficulty to } \\
\text { repalr or } \\
\text { replace hoses; } \\
\text { survey elevat ion } \\
\text { of readout } \\
\text { stat fons before } \\
\text { each } \\
\text { observation }\end{array}$ & $\begin{array}{l}\text { Install } \\
\text { reference } \\
\text { points on } \\
\text { structure; } \\
\text { provide } \\
\text { protection } \\
\text { for readout } \\
\text { and hoses } \\
\text { if permanent } \\
\text { installation }\end{array}$ & $\begin{array}{l}\text { Stople: two } \\
\text { techn tians } \\
\text { for portable } \\
\text { system, one } \\
\text { for permanent } \\
\text { installot ton; } \\
\text { repeat } \\
\text { measurement } \\
\text { for each } \\
\text { data point. } \\
\text { and allow: } \\
\text { ample time } \\
\text { for stilling } \\
\text { osetillations }\end{array}$ & None & $\begin{array}{l}\text { Convert pressure } \\
\text { differences or } \\
\text { graduated scale } \\
\text { reading to } \\
\text { elevation }\end{array}$ & $\begin{array}{l}\text { Multiple points } \\
\text { and terminal } \\
\text { point apparatus } \\
\text { \$150 to } \$ 500 \\
\text { deatiring unit } \\
\$ 300 \text { to } \$ 800\end{array}$ \\
\hline $\begin{array}{l}\text { Hoses must be } \\
\text { free of alr } \\
\text { bubbles. dirt. } \\
\text { algage: } \\
\text { difficult tc } \\
\text { repair or re. } \\
\text { place hoses; } \\
\text { survey } \\
\text { elevation of } \\
\text { readout } \\
\text { stat ion } \\
\text { before each } \\
\text { observation }\end{array}$ & $\begin{array}{l}\text { Hose placed } \\
\text { in trench of } \\
\text { uniform } \\
\text { grade be low } \\
\text { frost depth } \\
\text { and buried; } \\
\text { provide } \\
\text { protect ton } \\
\text { for readout } \\
\text { dervce; } \\
\text { readout } \\
\text { must be } \\
\text { installed } \\
\text { below } \\
\text { lowest } \\
\text { point } \\
\text { along hose }\end{array}$ & $\begin{array}{l}\text { Simple: one } \\
\text { persoon to } \\
\text { take reading }\end{array}$ & Mone & As above & $\begin{array}{l}\text { Readout } \$ 150 ; \\
\text { tubing } \$ 0.30 / \mathrm{ft} \\
\text { deatring unit } \\
\$ 3300 \text { to } \$ 800\end{array}$ \\
\hline As above & $\begin{array}{l}\text { As above; } \\
\text { install } \\
\text { readout at } \\
\text { same } \\
\text { elevation } \\
\text { as } \\
\text { manometer } \\
\text { hose }\end{array}$ & $\begin{array}{l}\text { Simple; one } \\
\text { person to } \\
\text { adjust } \\
\text { readout, } \\
\text { establish } \\
\text { estectric } \\
\text { contact, } \\
\text { and take } \\
\text { reading }\end{array}$ & Battery & As above & $\begin{array}{l}100 \mathrm{ft} \text { long } \\
\text { manometer wi th } \\
\text { readout, } \\
\text { electron ics, } \\
\text { mercury and } \\
\text { nitrogen } \\
\text { regulation, } \\
\text { single point } \\
\text { \$250, } \\
\text { multi-point } \\
\text { S45; } \\
\text { deatring unit } \\
\$ 300 \text { to } \$ 800\end{array}$ \\
\hline As above & $\begin{array}{l}\text { As above; } \\
\text { overf low } \\
\text { cell is } \\
\text { buried; } \\
\text { readout } \\
\text { must be } \\
\text { installed } \\
\text { be low } \\
\text { lowest } \\
\text { point } \\
\text { along hose }\end{array}$ & $\begin{array}{l}\text { Simple, one } \\
\text { person to } \\
\text { dod water, } \\
\text { conf itm } \\
\text { overf low } \\
\text { and get } \\
\text { reading }\end{array}$ & Mone & $\begin{array}{l}\text { Convert graduated } \\
\text { standp pe or } \\
\text { pressure gage } \\
\text { reading to } \\
\text { e levation }\end{array}$ & $\begin{array}{l}\text { Overf low cell } \\
\$ 32 ; \text { graduated } \\
\text { standpipe } \$ 35 ; \\
\text { tubing } \\
\$ 25 / 100 \text { ft: } \\
\text { deairing unit } \\
\$ 300 \text { to } \$ 800\end{array}$ \\
\hline As above & $\begin{array}{l}\text { Casing is } \\
\text { placed in } \\
\text { trench and } \\
\text { buried; } \\
\text { readout and } \\
\text { pulley } \\
\text { system } \\
\text { instailed } \\
\text { in pit with } \\
\text { protection } \\
\text { provided } \\
\end{array}$ & $\begin{array}{l}\text { One person } \\
\text { to move } \\
\text { prove, add } \\
\text { water, } \\
\text { confirm } \\
\text { overf low } \\
\text { and get } \\
\text { reading }\end{array}$ & Mone & As above & $\begin{array}{l}\text { Readout: } \\
\text { manual } \$ 3000 ; \\
\text { digital } \$ 4500\end{array}$ \\
\hline $\begin{array}{l}\text { Periodic } \\
\text { calibration } \\
\text { of trans- } \\
\text { ducer; } \\
\text { calibrate } \\
\text { steel tape } \\
\text { with } \\
\text { reference } \\
\text { tape or bar; } \\
\text { survey } \\
\text { elevation at } \\
\text { each readout } \\
\text { stattion } \\
\text { before each } \\
\text { observation }\end{array}$ & $\begin{array}{l}\text { Tube placed } \\
\text { along } \\
\text { trench, } \\
\text { kept } \\
\text { stratght. } \\
\text { brought to } \\
\text { surface on } \\
\text { gent le on } \\
\text { curve, and } \\
\text { buried }\end{array}$ & $\begin{array}{l}\text { One person } \\
\text { to move } \\
\text { probe and } \\
\text { take } \\
\text { reading }\end{array}$ & Battery & $\begin{array}{l}\text { Convert electric } \\
\text { readouts to } \\
\text { e levation }\end{array}$ & $\begin{array}{l}\text { Available with } \\
\text { e lectromagnetic } \\
\text { torpedo to } \\
\text { monitor } \\
\text { horizontal } \\
\text { movement } \$ 1500 ; \\
\text { casing } \$ 3 / \mathrm{ft}\end{array}$ \\
\hline $\begin{array}{l}\text { As above; } \\
\text { callbration } \\
\text { risers along } \\
\text { tube allow } \\
\text { for tn-situ } \\
\text { callibration } \\
\text { slong } \\
\text { profile }\end{array}$ & $\begin{array}{l}\text { Tubing with } \\
\text { calibration } \\
\text { rtssers. } \\
\text { placed along } \\
\text { trench of } \\
\text { uniform } \\
\text { grade below } \\
\text { frost depth } \\
\text { and buried } \\
\end{array}$ & $\begin{array}{l}\text { One person } \\
\text { to move two } \\
\text { liquid } \\
\text { interf ace } \\
\text { along tube. } \\
\text { calibrate } \\
\text { and take } \\
\text { readings }\end{array}$ & $\begin{array}{l}\text { Mone for } \\
\text { manual } \\
\text { readout; } \\
\text { battery for } \\
\text { auteanatic } \\
\text { readout }\end{array}$ & $\begin{array}{l}\text { Convert readings } \\
\text { on pressure gage } \\
\text { to elevation for } \\
\text { manual readout. } \\
\text { Automatic } \\
\text { readout gives } \\
\text { sealed chart } \\
\text { recording of } \\
\text { tubing elevat ion } \\
\end{array}$ & $\begin{array}{l}\text { Tubing } \$ 0.30 / \mathrm{ft}^{\prime} \\
\text { manual readout } \\
\text { \$4000; } \\
\text { sutomatic } \\
\text { readout } \\
\$ 5500\end{array}$ \\
\hline $\begin{array}{l}\text { Mone: } \\
\text { difficult } \\
\text { to remove } \\
\text { sensors for } \\
\text { repair or } \\
\text { replacenent }\end{array}$ & $\begin{array}{l}\text { Install } \\
\text { sensors in } \\
\text { flextble } \\
\text { casing along } \\
\text { trench and } \\
\text { bury }\end{array}$ & $\begin{array}{l}\text { Simple, one } \\
\text { person to } \\
\text { adjust } \\
\text { levels and } \\
\text { take reading }\end{array}$ & $D-25$ & $\begin{array}{l}\text { Convert voltage } \\
\text { or digit ai } \\
\text { readout to } \\
\text { displacement }\end{array}$ & \\
\hline
\end{tabular}


TABLE D-1 - InStRUMENT CAPABILItIES (CONTINUED)

\begin{tabular}{|c|c|c|c|c|c|c|c|}
\hline INSTRUMENT & AVAILABILITY & $\begin{array}{l}\text { INSTRLMENT } \\
\text { CHARACTERISTICS }\end{array}$ & $\begin{array}{c}\text { COLLE } \\
\text { CHARACTE } \\
\text { REMOTE } \\
\text { OR } \\
\text { DIRECT }\end{array}$ & $\begin{array}{l}\text { ATA } \\
\text { ECTION } \\
\text { ERISTICS } \\
\text { ENTER } \\
\text { SUBSID- } \\
\text { ENCE } \\
\text { AREA } \\
\end{array}$ & RANGE & ACCURACY & $\begin{array}{l}\text { SENSITIVITY } \\
\text { TO } \\
\text { ENVIRONMENT }\end{array}$ \\
\hline $\begin{array}{l}\text { Electrolytic type } \\
\text { tlltmeter } \\
\text { (ground } t i 1 t \text { ) }\end{array}$ & BAC & $\begin{array}{l}\text { Portable; long } \\
\text { service records; } \\
\text { permanent } \\
\text { installation for } \\
\text { best accuracy }\end{array}$ & Renote & Yes & $\begin{array}{l}0.5 \text { to } 1.0 \\
\text { degree }\end{array}$ & $\begin{array}{l}1.0 \text { to } 2.0 \\
\text { seconds of } \\
\text { arc }\end{array}$ & $\begin{array}{l}\text { Sensitive to } \\
\text { temperature; possible } \\
\text { electric problens } \\
\text { including zero drift } \\
\text { due to residual } \\
\text { instability of metals } \\
\text { and cements; } \\
\text { permanent installation } \\
\text { may be subject to } \\
\text { vandalism }\end{array}$ \\
\hline $\begin{array}{l}\text { Soirit level } \\
\text { type tiltmeter } \\
\text { (ground } t(1 t)\end{array}$ & Galileo & $\begin{array}{l}\text { Portable; rugged } \\
\text { long operating } \\
\text { life }\end{array}$ & Direct & Yes & $\begin{array}{l}0.5 \text { to } 1.0 \\
\text { degree }\end{array}$ & $\begin{array}{l}5.0 \text { to } \\
10.0 \\
\text { seconds of } \\
\text { arc }\end{array}$ & $\begin{array}{l}\text { Moderately sensitive } \\
\text { to temperature; } \\
\text { reference points may } \\
\text { be subject to } \\
\text { vandalism }\end{array}$ \\
\hline $\begin{array}{l}\text { Vibrating wire } \\
\text { type tiltmeter } \\
\text { (ground tilt) }\end{array}$ & $\begin{array}{l}\text { Telemac; } \\
\text { Maihak }\end{array}$ & $\begin{array}{l}\text { Portable, rugged } \\
\text { long term } \\
\text { stability }\end{array}$ & Remote & Yes & 1.5 degree & $\begin{array}{l}0.3 \text { to } \\
10.0 \\
\text { seconds of } \\
\text { arc }\end{array}$ & $\begin{array}{l}\text { Relatively insensitive } \\
\text { to temperature or } \\
\text { moisture; reference } \\
\text { points may be subject } \\
\text { to vandalism }\end{array}$ \\
\hline $\begin{array}{l}\text { Rod extenso- } \\
\text { meter with } \\
\text { micrometer and } \\
\text { spirit level } \\
\text { (ground tilt) }\end{array}$ & $\begin{array}{l}\text { Micro } \\
\text { Precision } \\
\text { Engrg; } \\
\text { Galileo }\end{array}$ & Portable; rugged & Remote & Yes & $\begin{array}{l}0.5 \text { to } 1.0 \\
\text { degree }\end{array}$ & $\begin{array}{l}5.0 \text { to } \\
10.0 \\
\text { seconds of } \\
\text { arc }\end{array}$ & $\begin{array}{l}\text { Moderately sensitive } \\
\text { to temperature; } \\
\text { reference points may } \\
\text { be subject to } \\
\text { vandalism }\end{array}$ \\
\hline $\begin{array}{l}\text { Rod extenso- } \\
\text { meter with } \\
\text { leveling } \\
\text { bubble and } \\
\text { levelling } \\
\text { screw, and } \\
\text { linear } \\
\text { potent fometer, } \\
\text { Lvot, or dial } \\
\text { gauge } \\
\text { (ground tilt) }\end{array}$ & $\begin{array}{l}\text { User } \\
\text { fabricated; } \\
\text { Hendron, } \\
\text { et al, } \\
(1975) \\
\text { Nason }(1971)\end{array}$ & $\begin{array}{l}\text { Permanent for } \\
\text { monitoring } \\
\text { period }\end{array}$ & Direct & Yes & $\begin{array}{l}5.0 \\
\text { degrees }\end{array}$ & $\begin{array}{l}50.0 \\
\text { seconds of } \\
\text { arc }\end{array}$ & $\begin{array}{l}\text { Susceptible to } \\
\text { corrosion and } \\
\text { vandalism unless } \\
\text { protected }\end{array}$ \\
\hline
\end{tabular}


Table D-1 (side 2)

\begin{tabular}{|c|c|c|c|c|c|}
\hline $\begin{array}{c}\text { CAL IBRATION } \\
\text { AND } \\
\text { MAINTENANCE }\end{array}$ & $\begin{array}{c}\text { EASE/COST } \\
\text { OF } \\
\text { INSTALLATION }\end{array}$ & $\begin{array}{l}\text { EASE/COST } \\
\text { OF } \\
\text { OPERATION }\end{array}$ & $\begin{array}{c}\text { POWER } \\
\text { REQUIREMENTS }\end{array}$ & $\begin{array}{c}\text { EASE/COST } \\
\text { OF } \\
\text { DATA REDUCTION }\end{array}$ & $\begin{array}{c}\text { COST } \\
\text { OF } \\
\text { INSTRUAENT }\end{array}$ \\
\hline $\begin{array}{l}\text { Check for } \\
\text { zero drift }\end{array}$ & $\begin{array}{l}\text { Install base } \\
\text { plates on } \\
\text { reference } \\
\text { stations }\end{array}$ & $\begin{array}{l}\text { One person } \\
\text { with } \\
\text { moderate } \\
\text { training } \\
\text { to take } \\
\text { reading; } \\
\text { portable } \\
\text { device must } \\
\text { be mounted } \\
\text { on base } \\
\text { plate for } \\
\text { each } \\
\text { reading }\end{array}$ & Battery & $\begin{array}{l}\text { Convert digital } \\
\text { readout to tilt } \\
\text { angle }\end{array}$ & $\begin{array}{l}\text { readout } \$ 1500 ; \\
\text { stations to } \\
\text { S100 each }\end{array}$ \\
\hline $\begin{array}{l}\text { Check zero } \\
\text { by readings } \\
\text { at } 180 \\
\text { degrees. }\end{array}$ & As above & $\begin{array}{l}\text { Simple; one } \\
\text { person to } \\
\text { mount level } \\
\text { and read }\end{array}$ & None & $\begin{array}{l}\text { Simple; direct } \\
\text { readout of tilt } \\
\text { angle is given }\end{array}$ & $\begin{array}{l}\text { readout } \$ 1200 ; \\
\text { stations to } \\
\$ 100 \text { each }\end{array}$ \\
\hline None & As above & $\begin{array}{l}\text { One person } \\
\text { to mount } \\
\text { tiltmeter } \\
\text { and take } \\
\text { reading; } \\
\text { time and } \\
\text { training } \\
\text { required } \\
\text { depends on } \\
\text { readout } \\
\text { device used }\end{array}$ & Battery & $\begin{array}{l}\text { Convert vibrating } \\
\text { frequency, analog } \\
\text { reading, or } \\
\text { digital readout } \\
\text { to tilt angle }\end{array}$ & $\begin{array}{l}\text { Tiltmeter } \$ 1200 \text {; } \\
\text { readout } \$ 3000 \\
\text { to } \$ 4500\end{array}$ \\
\hline Mone & As above & $\begin{array}{l}\text { One person } \\
\text { with } \\
\text { moderate } \\
\text { training to } \\
\text { mount } \\
\text { tiltmeter } \\
\text { and take } \\
\text { reading }\end{array}$ & Battery & $\begin{array}{l}\text { Convert digital } \\
\text { readout to tilt } \\
\text { angle }\end{array}$ & $\begin{array}{l}\text { Tiltmeter } \\
\$ 2900 ; \\
\text { readout } \\
\$ 1100\end{array}$ \\
\hline $\begin{array}{l}\text { Check zero } \\
\text { by readings } \\
\text { at } 180 \\
\text { degrees }\end{array}$ & $\begin{array}{l}\text { Reference } \\
\text { points } \\
\text { embedded in } \\
\text { soil, rock } \\
\text { or structure }\end{array}$ & $\begin{array}{l}\text { One person } \\
\text { with } \\
\text { moderate } \\
\text { training to } \\
\text { mount bar, } \\
\text { adjust leve } 1 \\
\text { and read }\end{array}$ & None & $\begin{array}{l}\text { Simple; direct } \\
\text { readout of tilt } \\
\text { angle is given }\end{array}$ & $\$ 3500$ \\
\hline None & $\begin{array}{l}\text { Extensoneter } \\
\text { mounted on } \\
\text { reference } \\
\text { points } \\
\text { embedded in } \\
\text { soll, rock } \\
\text { or structure }\end{array}$ & $\begin{array}{l}\text { Simple, one } \\
\text { person to } \\
\text { adjust screw } \\
\text { and take } \\
\text { reading }\end{array}$ & Mone & $\begin{array}{l}\text { Convert leveling } \\
\text { screw reading } \\
\text { to tilt angle }\end{array}$ & $\$ 1500$ to $\$ 3500$ \\
\hline
\end{tabular}


the basis of relevancy to monitoring of surface movements at producing geothermal fields. The data and comments are intended to indicate the capabilities of the instruments when used in a typical program of conscientious field operations. Also, the listed capabilities are an assessment of a type of instrument (e.g., rod extensometer or wire extensometer) and do not apply specifically to any individual manufacturer's product. Thus, by special care and skill in the selection, installation, and use of instruments in the field, accuracy greater than that given in the table for the instrument type may be obtained.

In some instances one or more manufacturers or suppliers names or equipment model are given. This is for the purpose of simplifying the description of the instrument type, and is not to be construed as an endorsement of the equipment, manufacturer, or supplier.

Since, in many instances, more than one type of equipment may be used to perform a specific monitoring function, it would be helpful to rate these instruments in terms of the comparative ability to perform the specific function. Table $0-2$ presents a system for such comparison of capabilities of instrument systems. For this table, five monitoring functions are recognized: network monitoring of horizontal movements and of vertical movements, and special monitoring of horizontal strain, of vertical movements in inaccessible locations, and of surface tilt. In arriving at a numerical rating twe ive variables were considered, as described below:

1. Availability - the availability of the instrument from commercial manufacturers. Since only instruments which are available are included here, delivery time is a primary factor in considering relative availability.

2. Physical characteristics - such characteristics as portability, permanence of installation, ruggedness, and operating life are considered. 


\begin{tabular}{|c|c|c|c|c|c|c|c|c|c|c|c|c|c|c|}
\hline & Weighting Factor & & 1 & 2 & 1 & 2 & 3 & 3 & 2 & 2 & 2 & 1 & 3 & 3 \\
\hline 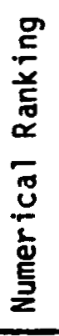 & $\begin{array}{l}\text { A - VERTICAL } \\
\text { MOVEMENTS }\end{array}$ & $\begin{array}{l}\vec{a} \\
\leftarrow \\
⺊ \\
0 \\
\vdash\end{array}$ & 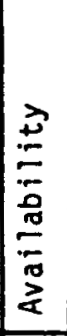 & 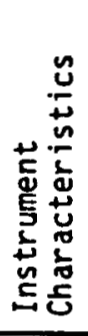 & 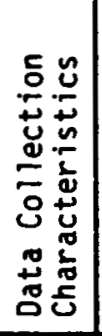 & 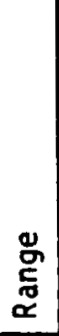 & 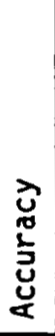 & 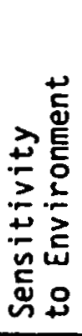 &  &  & 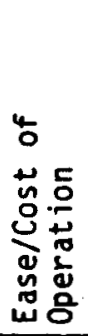 & 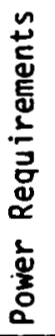 & 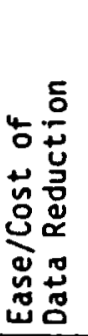 & 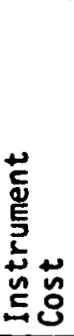 \\
\hline 1 & $\begin{array}{l}\text { Precision Level and } \\
\text { Invar rod }\end{array}$ & 61 & 3 & 3 & 1 & 3 & 3 & 3 & 2 & 2 & 2 & 3 & 2 & 2 \\
\hline 2 & Theodolite (as level) & 56 & 3 & 2 & 1 & 3 & 2 & 3. & 2 & 2 & 2 & 3 & 2 & 2 \\
\hline
\end{tabular}

\begin{tabular}{|c|c|c|c|c|c|c|c|c|c|c|c|c|c|c|}
\hline & \multicolumn{2}{|c|}{ Weighting Factor } & 1 & 2 & 1 & 2 & 3 & 3 & 2 & 2 & 2 & 1 & 3 & 3 \\
\hline 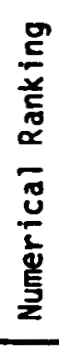 & $\begin{array}{l}\text { B - HORIZONTAL } \\
\text { MOVEMENTS }\end{array}$ & $\begin{array}{l}1 \\
5 \\
5 \\
5\end{array}$ & 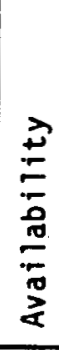 & 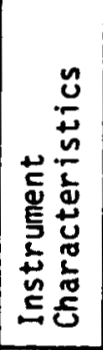 &  &  & 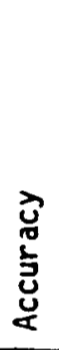 &  &  & 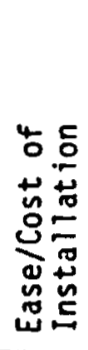 & 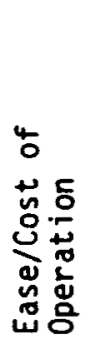 & 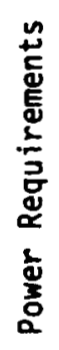 &  & 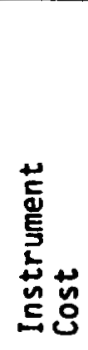 \\
\hline 1 & $\begin{array}{l}\text { Infrared EDM and Theodolite } \\
\text { (trilateration) }\end{array}$ & 54 & 3 & 3 & 2 & 3 & 2 & 2 & 2 & 2 & 3 & 2 & 1 & 2 \\
\hline 3 & $\begin{array}{l}\text { Optical ECM and Theodolite } \\
\text { (trilateration) }\end{array}$ & 50 & 2 & 3 & 2 & 3 & 2 & 2 & 2 & 2 & 3 & 2 & 1 & 1 \\
\hline 4 & $\begin{array}{l}\text { Laser EDM and Theodolite } \\
\text { (trilateration) }\end{array}$ & 47 & 2 & 3 & 2 & 3 & 2 & 1 & 2 & 2 & 3 & 2 & 1 & 1 \\
\hline 2 & $\begin{array}{l}\text { Precision Theodolite and Tape } \\
\text { (triangulation) }\end{array}$ & 52 & 3 & 3 & 1 & 3 & 1 & 3 & 3 & 2 & 1 & 3 & 1 & 2 \\
\hline
\end{tabular}

TABLE D-2 - COMPARISON OF CAPABILITIES OF INSTRUMENT SYSTEMS

(Surmarized from "Subsidence Monitoring Systems for Undermined Areas" J. E. O'Rourke et a1, WCC, 1977) 


\begin{tabular}{|c|c|c|c|c|c|c|c|c|c|c|c|c|c|c|}
\hline & & Weighting Factor & 1 & 2 & 1 & 2 & 3 & 3 & 2 & 2 & 2 & 1 & 3 & 3 \\
\hline 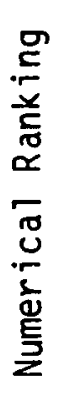 & $\begin{array}{c}C-\text { SPECIAL MONITORING } \\
\text { HORIZONTAL STRAIN }\end{array}$ & 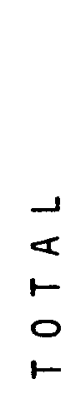 & 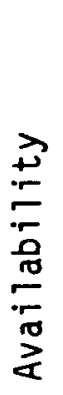 & 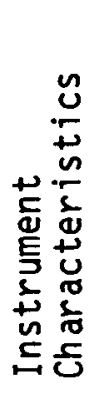 & 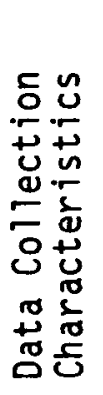 & 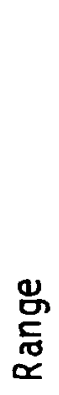 & 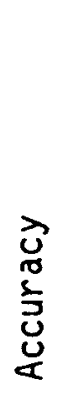 & 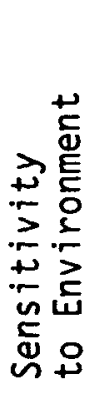 & 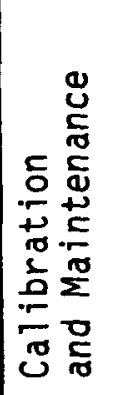 &  & 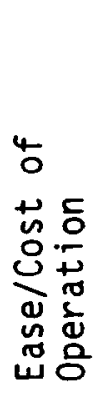 &  & 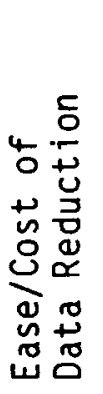 & 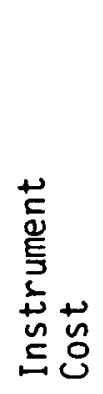 \\
\hline 1 & Steel Tape & 64 & 3 & 3 & 1 & 3 & 2 & 2 & 3 & 3 & 3 & 3 & 2 & 3 \\
\hline 2 & Invar Tape & 63 & 3 & 3 & 1 & 3 & 3 & 3 & 2 & 3 & 2 & 3 & 2 & 2 \\
\hline 3 & Steel Tape Extensometer & 58 & 3 & 3 & 1 & 2 & 3 & 2 & 3 & 1 & 3 & 3 & 2 & 2 \\
\hline 6 & Invar Wire Extensometer & 53 & 2 & 2 & 1 & 2 & 3 & 3 & 3 & 1 & 2 & 3 & 2 & 1 \\
\hline 5 & $\begin{array}{l}\text { Rod Extensometer with } \\
\text { Machinist's Scale }\end{array}$ & 54 & 1 & 2 & 1 & 2 & 3 & 2 & 3 & 1 & 3 & 3 & 2 & 2 \\
\hline 6 & $\begin{array}{l}\text { Rod Extensometer with } \\
\text { Micrometer }\end{array}$ & 53 & 2 & 3 & 1 & 1 & 3 & 2 & 3 & 1 & 2 & 3 & 2 & 2 \\
\hline 4 & $\begin{array}{l}\text { Rod Extensometer with } \\
\text { Dial Gauge }\end{array}$ & 55 & 2 & 2 & 1 & 2 & 3 & 2 & 3 & 1 & 3 & 3 & 2 & 2 \\
\hline 9 & Rod Extensometer with LVDT & 43 & 1 & 1 & 2 & 1 & 3 & 1 & 2 & 1 & 2 & 2 & 2 & 2 \\
\hline 8 & $\begin{array}{l}\text { Rod Extensometer with Linear } \\
\text { Potentiometer }\end{array}$ & 46 & 2 & 1 & 2 & 2 & 3 & 1 & 2 & 1 & 2 & 2 & 2 & 2 \\
\hline
\end{tabular}

TABLE D-2 - COMPARISON OF CAPABILITIES OF INSTRUMENT SYSTEMS (Continued) 


\begin{tabular}{|c|c|c|c|c|c|c|c|c|c|c|c|c|c|c|}
\hline & & Weighting Factor & \multirow{2}{*}{ 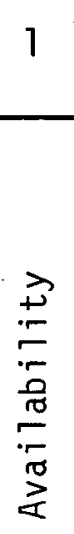 } & \multirow{2}{*}{  } & \multirow{2}{*}{  } & \multirow{2}{*}{$\begin{array}{l}2 \\
\\
\end{array}$} & \multirow{2}{*}{$\begin{array}{l}3 \\
\\
\\
\\
\grave{0} \\
0 \\
\vdots \\
0 \\
0 \\
\vdots\end{array}$} & \multirow{2}{*}{ 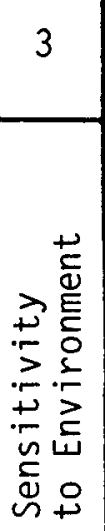 } & \multirow{2}{*}{ 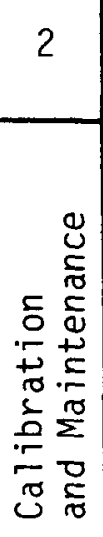 } & \multirow{2}{*}{ 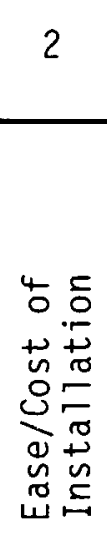 } & \multirow{2}{*}{ 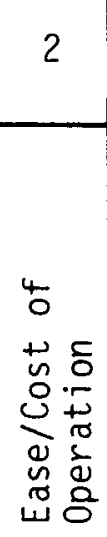 } & \multirow{2}{*}{ 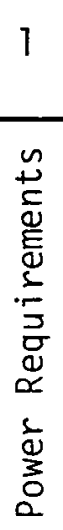 } & \multirow{2}{*}{  } & \multirow{2}{*}{ 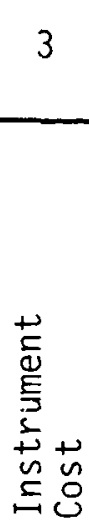 } \\
\hline  & $\begin{aligned} D- & \text { SPECIAL MONITORING } \\
& \text { VERTICAL, INACCESSIBLE }\end{aligned}$ & $\begin{array}{l}-1 \\
\alpha \\
\vdash \\
0 \\
1\end{array}$ & & & & & & & & & & & & \\
\hline 2 & $\begin{array}{l}\text { M.P. Terzaghi Differential } \\
\text { Settlement Manometer }\end{array}$ & 56 & 3 & 2 & 2 & 3 & 1 & 2 & 2 & 3 & 2 & 3 & 2 & 3 \\
\hline 1 & S.P. Simple Hose Manometer & 60 & 3 & 1 & 2 & 3 & 3 & 2 & 2 & 2 & 3 & 3 & 2 & 3 \\
\hline 7 & $\begin{array}{l}\text { S.P. Electrical contact-type } \\
\text { Hose Manometer }\end{array}$ & 45 & 2 & 1 & $?$ & 1 & 2 & 1 & 2 & 2 & 3 & 2 & 2 & 2 \\
\hline 2 & S.P. Overflow type Manometer & 56 & 3 & 1 & 2 & 1 & 3 & 2 & 2 & 2 & 3 & 3 & 2 & 3 \\
\hline 2 & F.P. Overflow type Manometer & 56 & 2 & 1 & 2 & 3 & 3 & 2 & 2 & 2 & 3 & 3 & 2 & 2 \\
\hline 5 & $\begin{array}{l}\text { F.P. Two Liquid Pressure } \\
\text { Balance Manometer }\end{array}$ & 48 & 1 & 1 & 2 & 3 & 3 & 2 & 2 & 1 & 2 & 3 & 2 & 1 \\
\hline 9 & $\begin{array}{l}\text { F.P. Air Balloon in Liquid } \\
\text { Filled Tube Settlement Device }\end{array}$ & 39 & 2 & 1 & 2 & 3 & 1 & 1 & 2 & 1 & 2 & 2 & 2 & 1 \\
\hline 8 & $\begin{array}{l}\text { F.P. Inclinometer with Reed } \\
\text { Switch Torpedo (Horizontal casing) }\end{array}$ & 44 & 2 & 2 & 2 & 3 & 2 & 1 & 2 & 1 & 2 & 2 & 2 & 1 \\
\hline 5 & $\begin{array}{l}\text { F.P. Inclinometer with Electro- } \\
\text { magnetic Torpedo (Horiz. casing) }\end{array}$ & 48 & 3 & 2 & 2 & 3 & 2 & 1 & 2 & 1 & 2 & 2 & 2 & 2 \\
\hline
\end{tabular}

TABLE D-2 - COMPARISON OF CAPABILITIES OF INSTRUMENT SYSTEMS (Continued) 


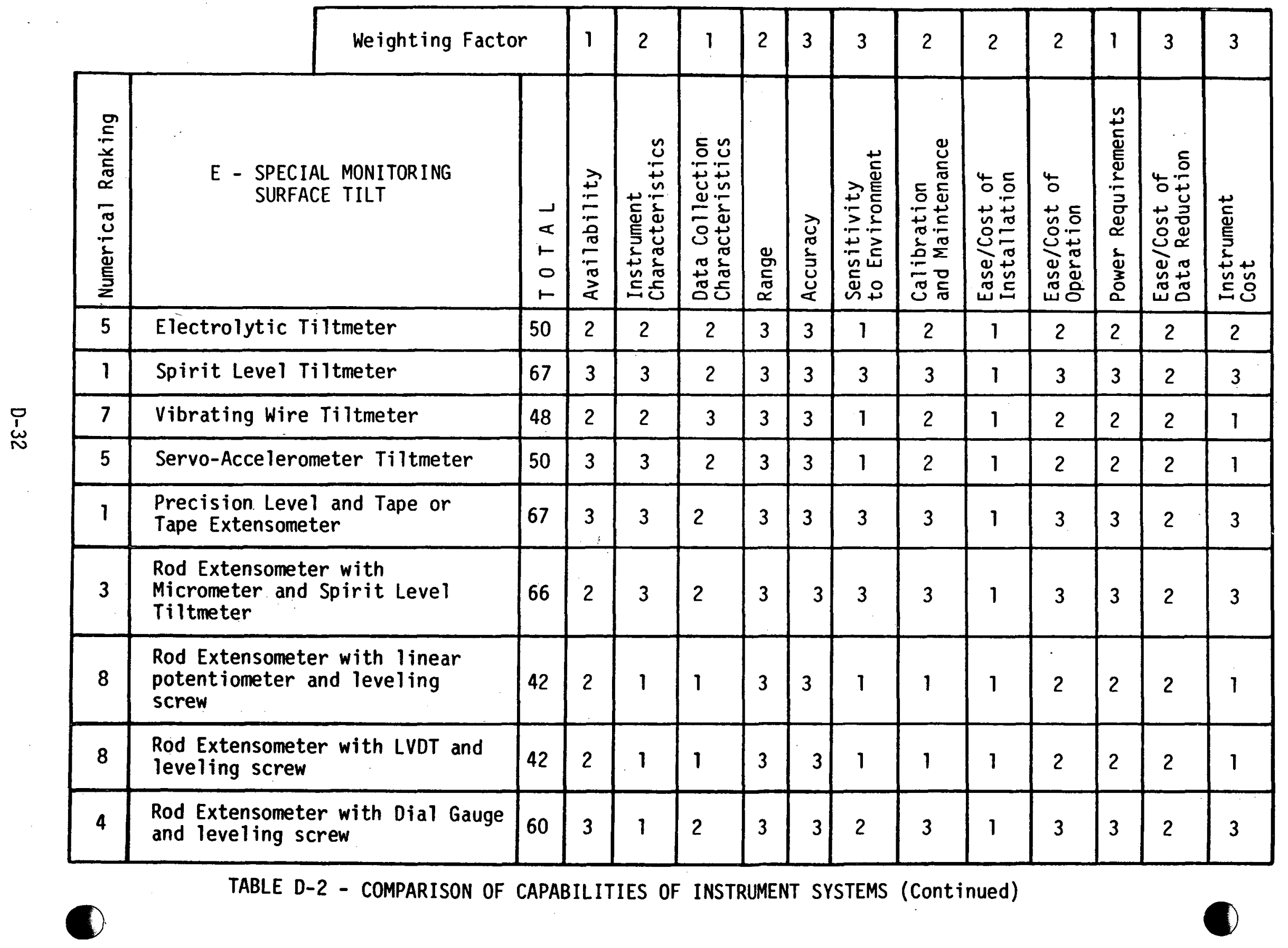


3. Data collection characteristics - considered are such factors as manual reading and recording, remote reading and recording, or automatic reading and recording, and the general degree of difficulty in collecting and recording the data.

4. Range - the difference between the minimum and maximum values of a measurement which can be obtained. For instruments which have unlimited range by repetition of measurements, the limits of an individual measurement and the difficulty of repeating measurements are considered.

5. Accuracy - the expected range of the difference between measured values and the true value.

6. Sensitivity to environment - the effect of such environmental factors as temperature, humidity, pressure, corrosive soil or atmosphere, shock, accidental damage, and dust or other pollutants on the instrument in such terms as life, maintenance cost, or accuracy.

7. Calibration and maintenance - the frequency of the need for calibration and maintenance, and the effects in terms of costs and periods of unavailability.

8. Ease and cost of installation - the relative skill and training required to install or otherwise place in readiness for operation, and the associated requirement for equipment and man-hours.

9. Ease and cost of operation - the relative skill and training required, and the time required for taking measurements.

10. Power requirements - the power required for instrument operation in the field, which may range from none to extensive requirements, such as for powered vehicles and continuous high voltage electrical power. 
11. Ease and cost of data reduction - the relative skill and training required in data reduction, and the associated requirement for auxiliary equipment and data such as computers and borehole data for correlation.

12. Instrument costs - the comparative initial cost of instruments and their associated hardware, such as readout devices, amplifiers, cables, and conduit.

Each instrument type is given a rating of 1, 2 or 3 for each of these twelve variables. These ratings are primarily judgmental, with 3 being most desirable, 2 about average, and 1 least desirable in terms of the variable considered. For example, the least costly of the instruments being compared would be rated as 3 , and the most expensive as 1 .

Since these variables are not considered to be of equal importance, a weighting factor was assigned to each. The greatest weight, a factor of 3, was assigned to four variables: accuracy, sensitivity to environment, ease and cost of data reduction, and instrument cost. The least weight, a factor of 1, was assigned to three variables: availability, data collection characteristics, and power requirements. An intermediate weighting factor of 2 was assigned to the remaining five variables: instrument characteristics, range, calibration and maintenance, ease and cost of installation, and ease and cost of operation. The rating given to an instrument for each variable is multiplied by the weighting factor for the variable, and the sum of these weighted ratings is taken as the overall rating for the instrument.

The ratings arrived at by means of this system should be considered as. examples only, since they do not apply to a specific site or set of conditions. However, the system may be readily used for a specific site by assigning ratings and weighting factors considered to be most appropriate to the site. The revised totals will then aid in identifying the instruments which best reflect the priorities of the site. 
The basic data obtained in monitoring of surface movements are the results of periodic determinations of the elevation and of the position of the bench marks comprising the level network. It is assumed that conventional survey procedures will be used for these determinations, and that these procedures will include field data recording and the associated calculations. In this appendix are presented suggested formats for tabulation and for graphical representation of the results of monitoring surveys.

\section{E.1 VERTICAL MEASUREMENTS}

Figure E-1 illustrates a general format which is suggested for use in tabulation of bench mark elevations, of the differences in elevation between successive elevation determinations, and of the total difference in elevation for the monitoring period. The first column is provided for the bench mark number or other identifying symbol. The elevation determined for each bench mark during the initial survey is entered in the second column. For each additional survey round three columns are provided: one for the measured elevation; one for the difference between the measured elevation and that for the immediate prior round; and one for the difference between the measured elevation and that for the first round, i.e., the tota 1 difference in elevation since the start of monitoring. If data from a number of adjacent bench marks are to be "grouped," a separate line may be assigned to each identified group and the calculated average values entered in the appropriate columns for each test round.

Figure E-2 presents, in the format of Figure E-1, a tabulation of the results of a portion of a fictional example of a level survey. In Figure E-3, the data from Figure E-2 is used to demonstrate how "contour" maps of equal vertical movements may be prepared. For exampie, in Figure E-3a the elevation differences between rounds $n$ and $(n+1)$ (from column 4 in Figure E-2) are plotted at the plan location of the bench mark. Contour lines are then 


\begin{tabular}{|c|c|c|c|c|c|c|c|c|c|}
\hline \multirow[b]{2}{*}{$\begin{array}{c}\text { Bench } \\
\text { Mark } \\
\text { Number } \\
\end{array}$} & \multicolumn{9}{|c|}{ Elevations and Elevation Differences, units } \\
\hline & $\begin{array}{c}\text { Elevation } \\
\text { Round A } \\
\text { (date) }\end{array}$ & \begin{tabular}{|c|} 
Elevation \\
Round B \\
(date) \\
\end{tabular} & $\begin{array}{c}\text { Elevation } \\
\text { Difference, } \\
\text { A to B } \\
\end{array}$ & $\begin{array}{l}\text { Elevation } \\
\text { Round C } \\
\text { (date) }\end{array}$ & $\begin{array}{c}\text { Elevation } \\
\text { Difference, } \\
\text { B to C }\end{array}$ & $\begin{array}{c}\text { Elevation } \\
\text { Difference, } \\
\text { A to C }\end{array}$ & $\begin{array}{l}\text { Elevat ion } \\
\text { Round D } \\
\text { (date) } \\
\end{array}$ & $\begin{array}{c}\text { Elevation } \\
\text { Difference, } \\
\text { C to D } \\
\end{array}$ & $\begin{array}{l}\text { Elevation } \\
\text { Difference, } \\
\text { A to D }\end{array}$ \\
\hline & & & & & & & & & \\
\hline & & & & & & & & & \\
\hline & & & & & & & & & \\
\hline & & & & & & & & & \\
\hline & & & & & & & & & \\
\hline & & & & & & & & & \\
\hline & & & & & & & & & \\
\hline & & & & & & & & & \\
\hline & & & & & & & & & \\
\hline & & & & & & & & & \\
\hline & & & & & & & & & \\
\hline & & & & & & & & & \\
\hline & & & & & & & & & \\
\hline & & & & & & & & & \\
\hline
\end{tabular}

FIGURE E-1 - FORMAT FOR TABULATION OF RESULTS OF LEVEL SURVEYS AND CALCULATION OF VERTICAL MOVEMENTS 


\begin{tabular}{|c|c|c|c|c|c|c|c|c|c|}
\hline \multirow[b]{2}{*}{$\begin{array}{c}\text { Bench } \\
\text { Mark } \\
\text { Number }\end{array}$} & \multicolumn{9}{|c|}{ Elevations and Elevation Differences, units } \\
\hline & $\begin{array}{l}\text { Elevation } \\
\text { Round n } \\
\text { (date) } \\
\end{array}$ & $\begin{array}{c}\text { Elevation } \\
\text { Round ( }(n+1) \\
\text { (date) } \\
\end{array}$ & $\begin{array}{c}\text { Elevation } \\
\text { Difference, } \\
n \text { to (n+i) } \\
\end{array}$ & $\begin{array}{c}\text { Elevation } \\
\text { Round }(n+2) \\
\text { (date) }\end{array}$ & $\begin{array}{c}\text { Elevation } \\
\text { Difference } \\
(n+1) \text { to }(n+2) \\
\end{array}$ & $\begin{array}{c}\text { Elevation } \\
\text { Difference, } \\
\text { n to }(n+2) \\
\end{array}$ & $\begin{array}{c}\text { Elevation } \\
\text { Round }(n+3) \\
\text { (date) } \\
\end{array}$ & $\begin{array}{c}\text { Elevation } \\
\text { Difference, } \\
(n+2) \text { to }(n+3) \\
\end{array}$ & $\begin{array}{l}\text { Elevation } \\
\text { oifference, } \\
n \text { to }(n+3) \\
\end{array}$ \\
\hline 101 & 272 & 261 & ו1- & 259 & -2 & -13 & 256 & -3 & -16 \\
\hline 102 & 270 & 263 & -7 & 261 & -2 & -9 & 257 & -4 & -13 \\
\hline 103. & 261 & 254 & -7 & 253 & -1 & -8 & 251 & -2 & -10 \\
\hline 104 & 279 & 271 & -8 & 270 & -1 & -9 & 268 & -2 & -11 \\
\hline 105 & 273 & 269 & -4 & 266 & -3 & -7 & 264 & -2 & -9 \\
\hline 106 & 270 & 270 & $-0-$ & 266 & -4 & -4 & 262 & -4 & -8 \\
\hline 107 & 282 & 278 & -4 & 277 & -1 & -5 & 274 & -3 & -8 \\
\hline 108 & 281 & 281 & $-0-$ & 278 & -3 & -3 & 275 & -3 & -6 \\
\hline 109 & 281 & 281 & $-0-$ & 281 & $-0-$ & $-0-$ & 279 & -2 & -2 \\
\hline & & & & & & & & & \\
\hline & & & & & & & & & \\
\hline & & & & & & & & & \\
\hline & & & & & & & & & \\
\hline
\end{tabular}

FIGURE E-2 - TABULATION OF THE RESULTS OF A PORTION OF A FICTIONAL EXAMPLE OF A LEVEL SURVEY 
drawn through points of equal elevation difference determined by interpolation between adjacent bench marks. Figures E-3-b and E-3-C are similarly developed for the same area for total elevation differences from rounds $n$ to $(n+2)$ and $n$ to $(n+3)$, respectively. Such "contour" maps should be helpful in visualizing the extent of the area subject to vertical subsidence, the shape of the subsidence basin, and areas of maximum subsidence.

In order to better visualize the rate, or changes in the rate, of vertical subsidence, a graph of time vs total subsidence may be prepared. A stylized example of such a graph is presented in Figure E-4. The total vertical subsidence measured during each survey round is plotted against elapsed time since the initial survey round. A separate graph may be prepared for each bench mark; the data from more than one bench mark may be plotted as separate lines on the same graph; or the average values for a group of bench marks may be plotted, either on a separate graph or together with plots of the data for the bench marks represented by the average.

\section{E.2 HORIZONTAL MEASUREMENTS}

Figure E-5 illustrates a general format which is suggested for use in tabulation of horizontal movements. As in Figure E-1, the bench mark number or other identifying symbol is entered in the first column. The magnitude and direction of horizontal movement between survey rounds $A$ and $B$ are entered in the first double column. Two double columns are provided for data from each additional survey round - one for the magnitude and direction of horizontal movements since the immediate prior round, and the second for the magnitude and direction of horizontal movements since the first round, i.e., total movements since the start of monitoring. It should be noted that the magnitude of movements are not necessarily additive from round to round since movements at a bench mark may not continue in the same direction.

Horizontal movements may be more easily compared if plotted. Figure E-6 is a simplified example of a graphical representation of horizontal movements as determined by five successive survey rounds. In this plot total movements 


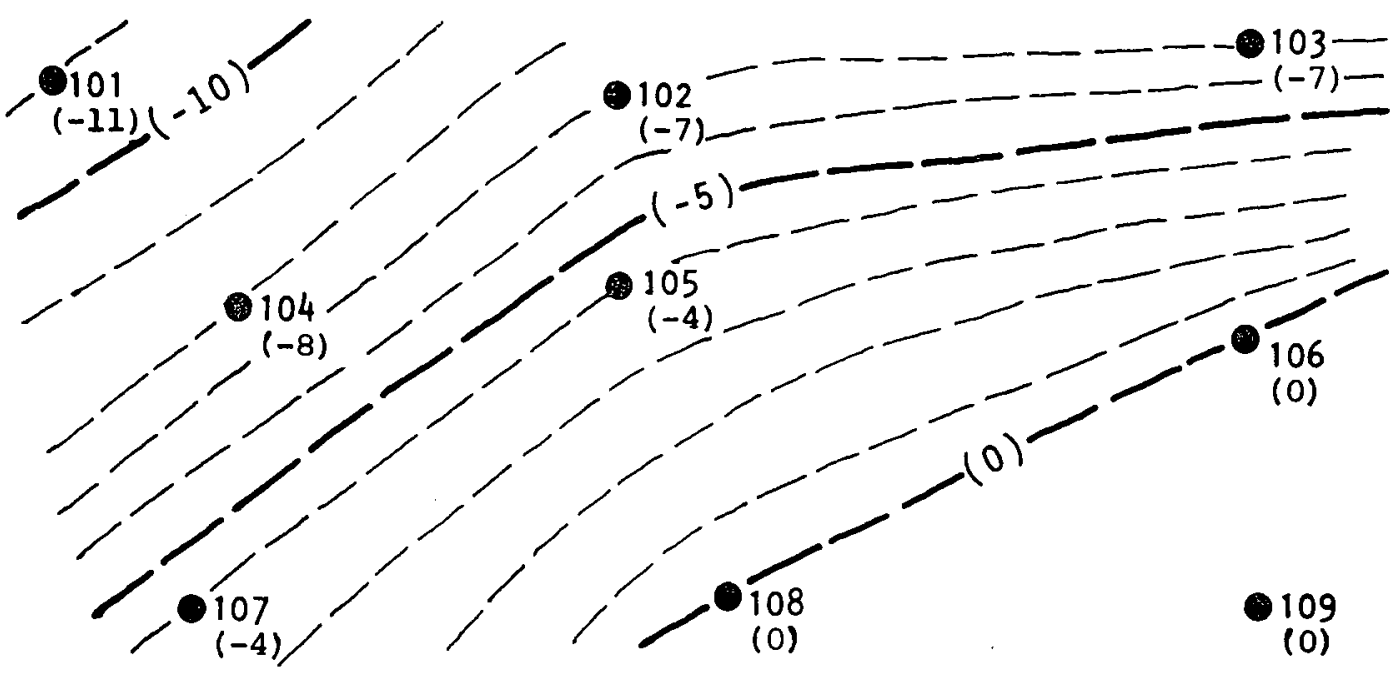

Figure $3 a$ - Round $n$ to $(n+1)$

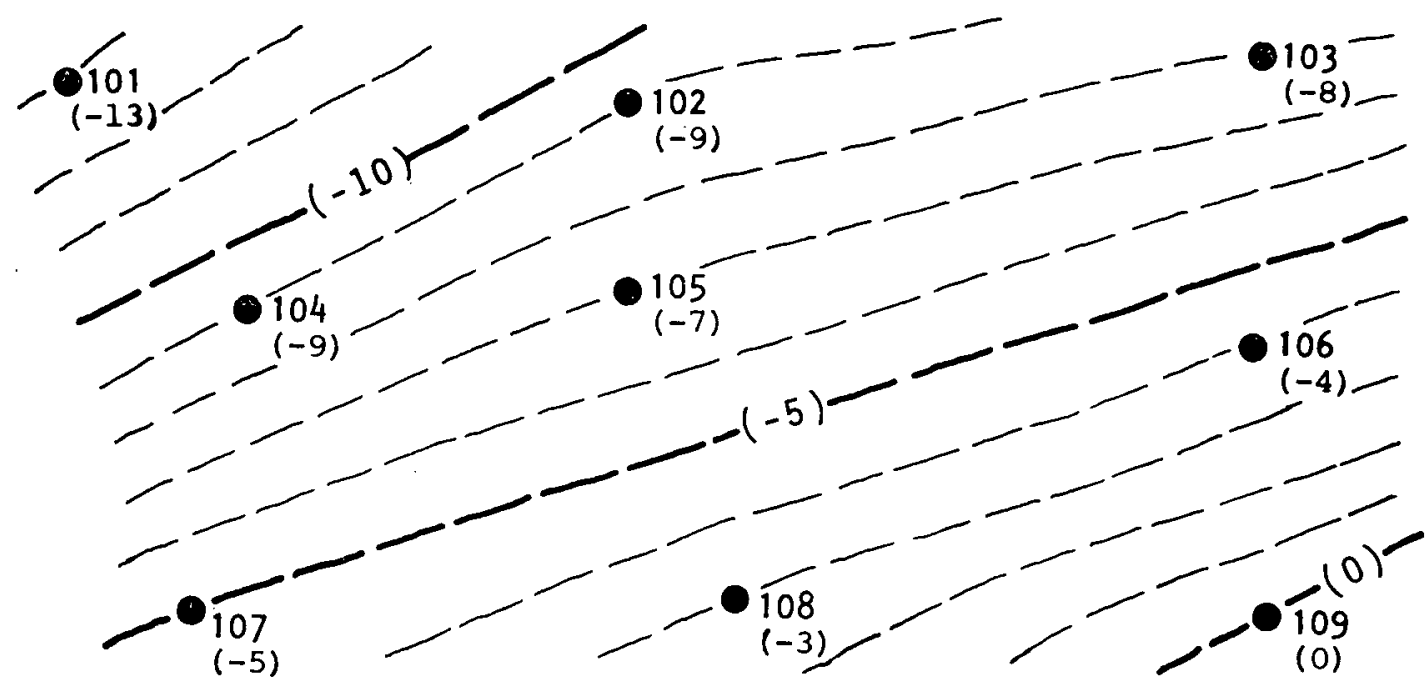

Figure $3 b$ - Round $n$ to $(n+2)$

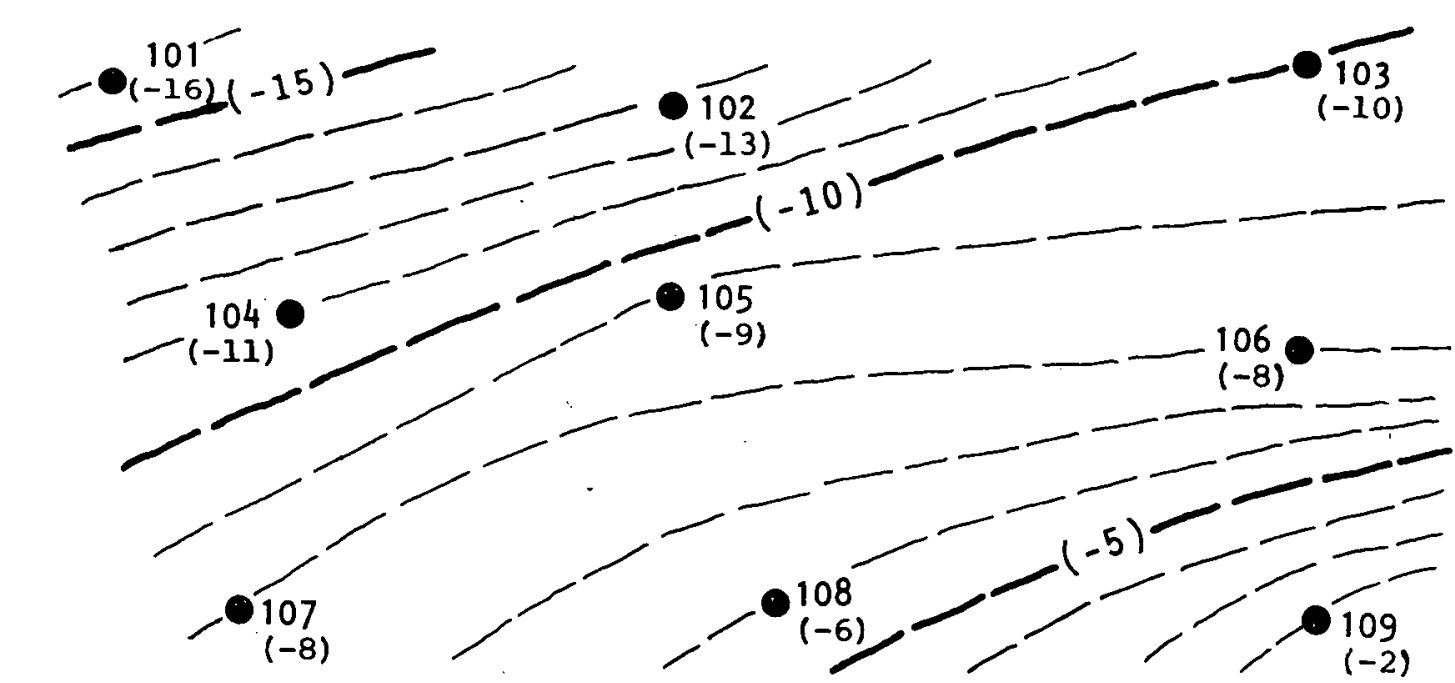

Figure $3 c$ - Round $n$ to $(n+3)$

FiguRE E-3 - SUBSIDENCE "CONTOURS" PLOTTED fROM TABULATION IN FIGURE 2 $\mathrm{E}-5$ 


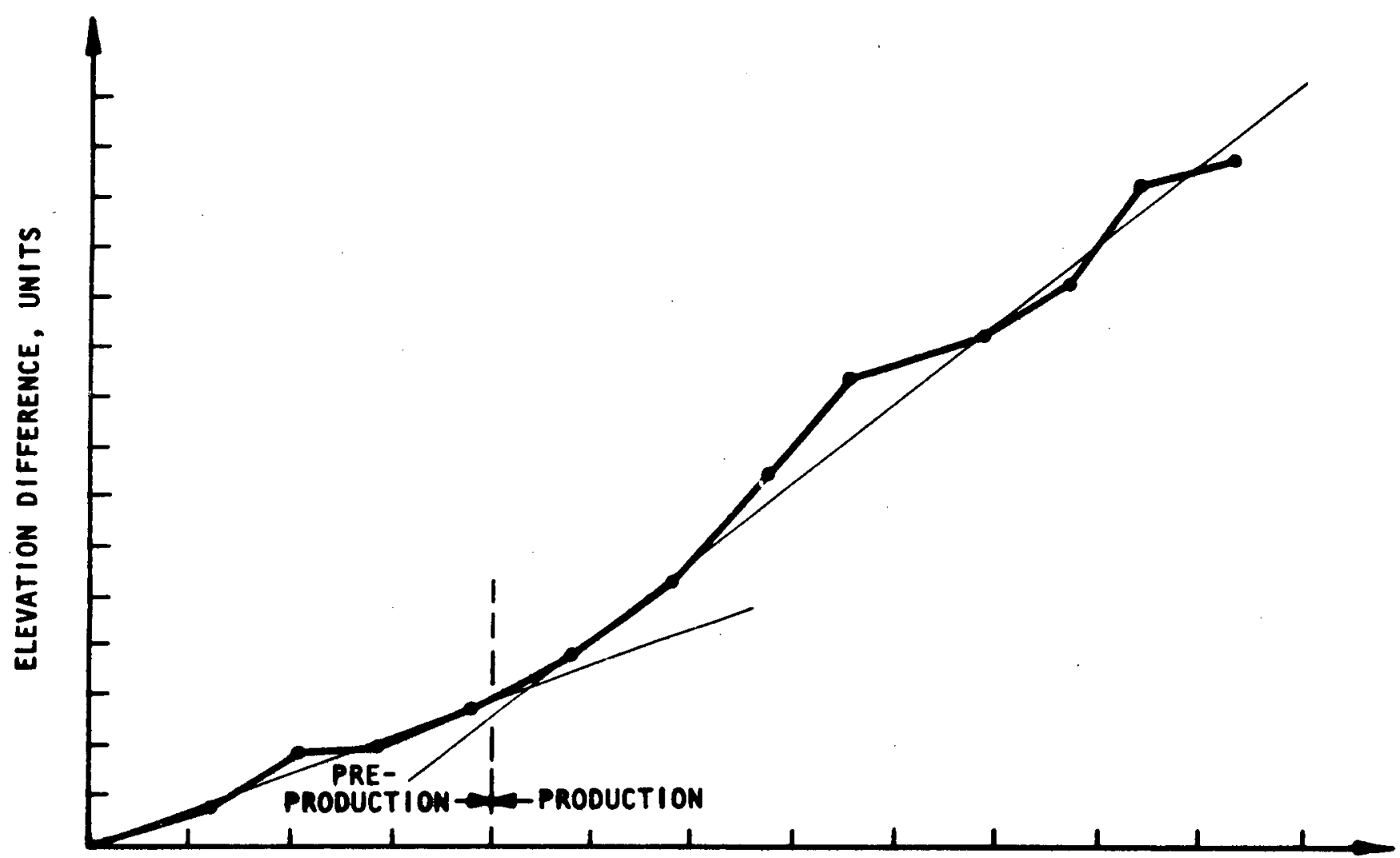

TIME UNITS

FIGURE E-4 - SIMPLIFIED EXAMPLE OF GRAPHICAL PRESENTATION OF RESULTS OF LEVEL SURVEY

$$
E-6
$$




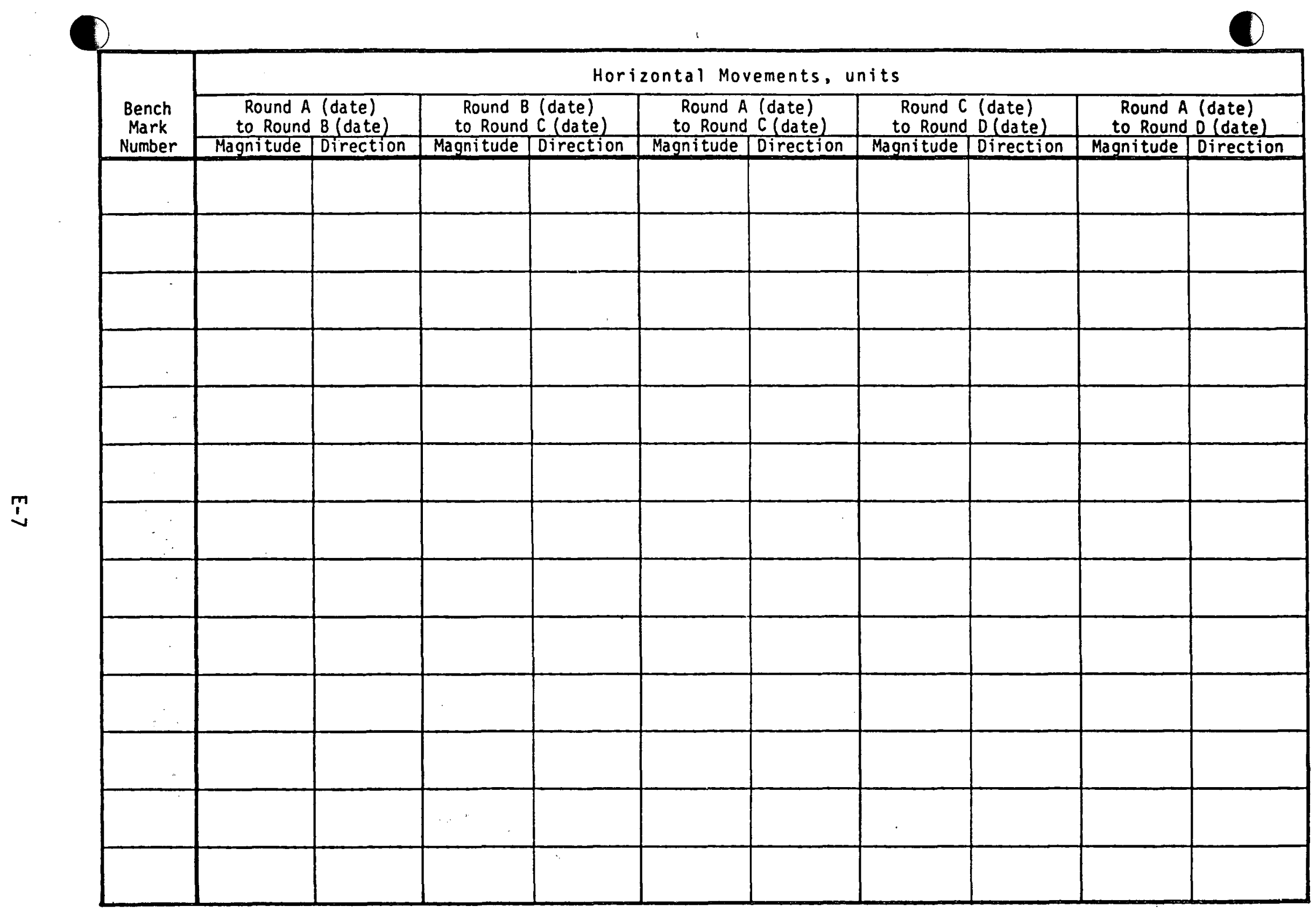

FIGURE E-5 - FORMAT FOR TABULATION OF RESULTS OF SURVEYS FOR DETERMINATION OF HORIZONTAL MOVEMENTS 


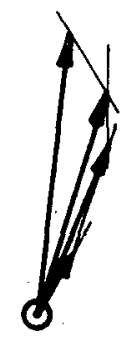

107
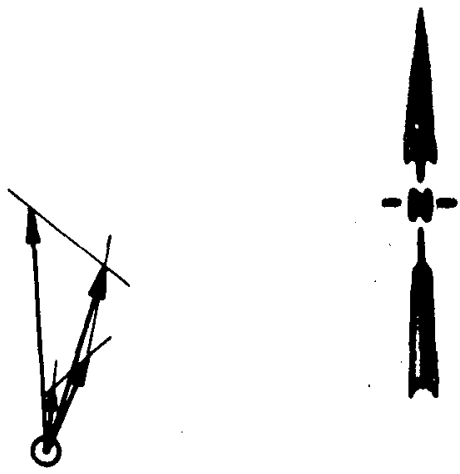

104
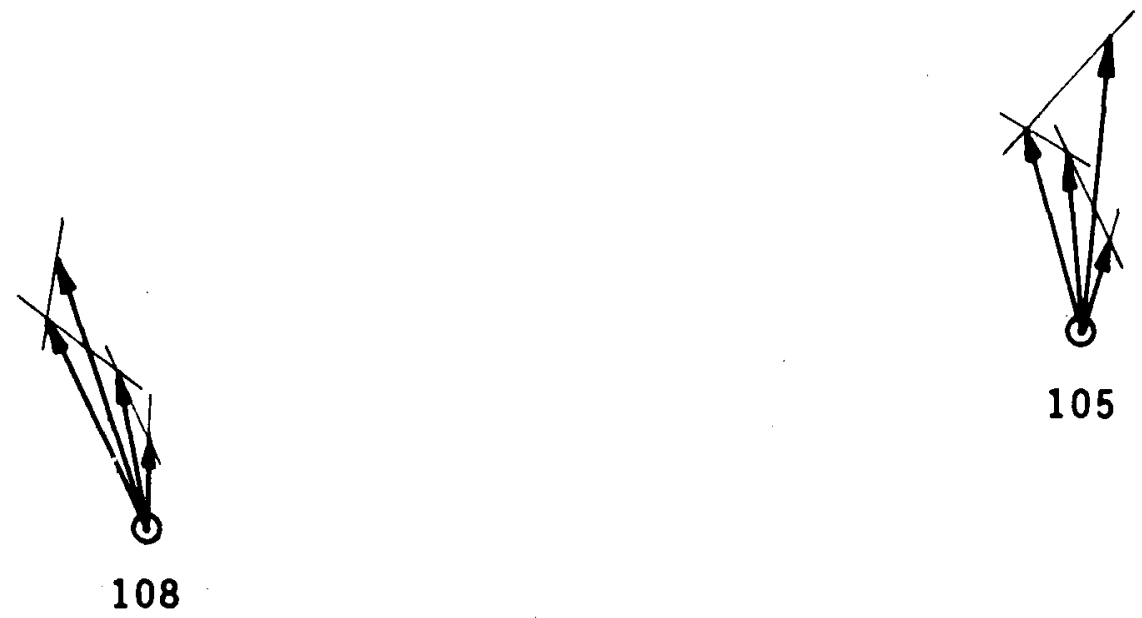

105

FIGURE E-6 - SIMPLIFIED EXAMPLE OF GRAPHICAL PRESENTATION OF HORIZONTAL MOVEMENTS

\section{$E-8$}


are represented by a vector whose origin is at the original map position of the bench mark and whose length represents the magnitude of total movement to some convenient exaggerated scale.

\section{E.3 ADDITIONAL DATA}

Data obtained from special monitoring, such as, from extensometers, tube profile devices, or tiltmeters, should be presented separately. No examples of format are presented here, since the method of tabulation or graphical presentation will be highly dependent on the arrangement and number of instruments, and the purpose of the instrumentation installation. It is suggested, however, that the general principle of tabulation of data separately for each survey interval and cumulatively to the date of survey be followed, if possible.

Graphical representation of data from special monitoring may also be helpful." For example, tiltmeter data may be presented in vector form (analogous to that illustrated in Figure E-6 for horizontal movements) or, if a considerable number of tiltmeters are used to give area coverage, it may be possible to develop "contour" maps of equal tilt (analogous to that illustrated in Figure E-3 for equal subsidence). 
APPENDIX $F$

STATISTICAL ANALYSES

\section{F. 1 NUMBER OF PRE-PRODUCTION OBSERVATIONS}

A study was made for the purpose of establishing guidelines for the determination of the minimum number of observations that should be performed prior to the start of geothermal production. In this context, "observation" refers to a determination of the horizontal or vertical position of a bench mark, or to the determination of a length, elevation, or position by means of special monitoring instruments. If a second observation is made at some later time, the difference in position is the movement which has occurred at that point during that period of time. Additional periodic observations may result in information which can be used to deduce changes in rate of movement with time.

The objective of these pre-production observations is to develop a historical record of movements which have occurred in the geothermal reservoir area from sources other than geothermal production. This record is used to establish a "base line" against which movements after production may be compared and the net movements attributable to geothermal production determined. The period of time available to establish a base line may be limited by the desire to start production at an early date. Thus a problem in planning the monitoring program is to determine the minimum number of periodic observations and the optimum period of time between observations necessary to establish a suitable base line. A detailed statistical analys is of this problem is relatively complex and may require a number of simplifying assumptions. However, some general guidelines have been suggested to estimate a reasonable number of observations. For example, D. R. Cox (Neter and Wasserman, 1974) has suggestions regarding the number of observations in a series which must be made for different purposes. These suggestions can be applied to subsidence monitoring as follows: 
1. Two observations - to determine if movement exists.

2. Three observations - when description of the time-movement curve by its approximate slope or curvature is adequate.

3. Four observations - when examination of the shape of the curve is desired.

4. Five or more observations - to estimate the detailed shape of the curve, or to show features (such as cyclic movements) not adequately described by slope and curvature.

In order to project base line movements into the future, it would be desirable to have the detail which can be obtained by five or more observations. Where time is available, and movements are relatively small, these observations should be made at intervals of at least a year. Where less time is available, the interval may be reduced in the interest of obtaining a greater number of observations, although there seems to be little advantage in making observations at intervals of less than six months because the movement in a smaller interval may not be significant. Within these constraints and under the assumptions that more than six years would seldom be available for pre-production monitoring and that less than two years would not provide an adequate base line, many alternative schedules are possible. Presented below are examples of some possible schedules, presented in decreasing order of preference. in each instance, observations would be made both at the beginning and at the end of the period, and at uniform intervals of either one year or six months.

1. Six year period, one year intervals, 7 observations

2. Five year period, one year intervals, 6 observations

3. Four year period, one year intervals, 5 observations

4. Three year period, 6 month intervals, 7 observations

5. Three year period, one year intervals, 4 observations

6. Two year period, 6 month intervals, 5 observations

7. Two year period, one year intervals, 3 observations 


\section{F.2 AVERAGING OF OBSERVATIONS}

In the previous section, it was assumed that each series of observations on a bench mark would be evaluated separately, i.e., that movements at each such point would be determined independently. If the desired accuracy cannot be obtained in this manner, greater accuracy may be obtainable by averaging a group of observations from adjacent bench marks. In order to do this, it must be assumed that the area represented by the group is moving as a unit, and the group, once selected, must remain intact throughout the monitoring period.

A statistical procedure is available for determining the level of confidence that the average value determined is within the desired accuracy. Following are definitions of the terms used in this procedure, as applied to subsidence monitoring as discussed in this report:

1. $n=$ the number of observations included in the group to be averaged.

2. $\bar{x}=$ the arithmetic average of the observations of the group, i.e., the sum of these observations divided by their number, $n$.

3. $s^{2}=$ the variance, a measure of the dispersion, or scatter, of the observations used to calculate $\bar{x}$

$$
s^{2}=\frac{1}{n} \sum_{i=1}^{n}\left(x_{i}-\bar{x}\right)^{2}
$$

4. $S=$ the standard deviation, another measure of the dispersion of the observations used to calculate $\bar{x}$

$$
S=+\sqrt{s^{2}}
$$

5. $C_{v}=$ coefficient of variation, the standard deviation divided by the average

$$
c_{v}=\frac{S}{\bar{x}}
$$


6. $P=$ percent accuracy, the range of values (in percent) in
which it is desired that the average be included

7. $F=$ confidence leve1, the probability (in percent) that the average lies within the range of the accuracy desired.

Table F-1 can be used to determine the level of confidence that an average value is within the desired accuracy. This table was constructed by computing the number of samples required to obtain a given level of confidence $(F)$ for a given coefficient of variation $\left(C_{V}\right)$ and percent accuracy $(P)$. For example, assume that the difference between two successive observations at 16 bench marks $(n=16)$ have been averaged, the coefficient of variation $\left(C_{v}\right)$ determined to be $2 \%$, and that the accuracy desired is $1 \%(P=1.0)$. By inspection it is seen that section $b$ of the table indicates that 16 observations are required for a coefficient of variation of $2 \%$ and an accuracy of $1.0 \%$-- and that this set of conditions gives a confidence level of $95 \%$.

A confidence level of $95 \%$ would usually be acceptable. However, the situation may arise where the confidence level is inacceptably low. It may be that the desired accuracy is unreasonably high and should be re-examined. Or examination of the data may show that a higher confidence level may be obtained by regrouping the observations to reduce the scatter, i.e., to obtain a lower coefficient of variation. It should again be pointed out that a group, once established, must remain the same throughout the monitoring period, including preproduction, production, and post-production.

\section{F.3 ANALYZING SUBSIDENCE DATA}

As discussed in Section F.1, it is essential that the monitoring schedule provide for sufficient measurements to be taken during the period immediately prior to production. The primary purpose of pre-production monitoring is to document any movements which may be occurring from sources other than withdrawal of geothermal fluids. Pre-production data thus establishes a "baseline" from which movements from geothermal production may be determined. 
TABLE F-1 - NUMBER OF OBSERVATIONS REQUIRED TO OBTAIN A GIVEN LEVEL OF CONFIDENCE FOR A CALCULATED COEFFICIENT OF VARIATION (CV) AND DESIRED PERCENT ACCURACY (P)

4-a $\quad 99 \%$ Confidence Leve]

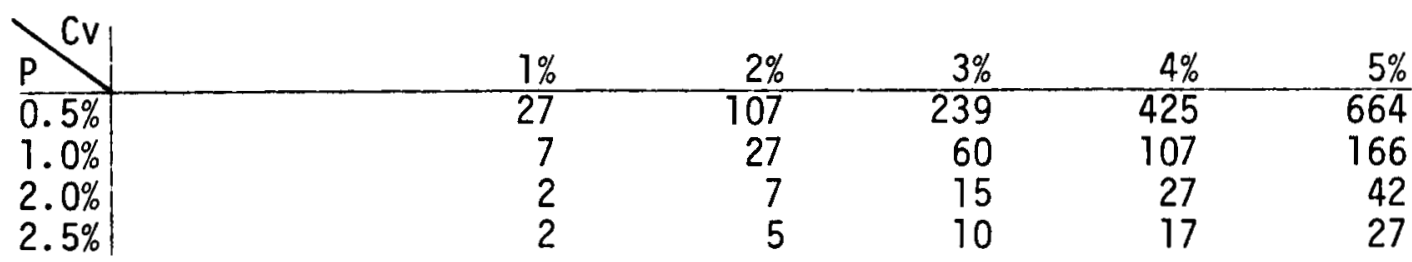

4-b $\quad 95 \%$ Confidence Leve1

\begin{tabular}{lrrrrr} 
& & & & \\
$\mathrm{P}$ & $1 \%$ & $2 \%$ & $3 \%$ & $4 \%$ & $5 \%$ \\
\hline $0.5 \%$ & 16 & 62 & 139 & 246 & 385 \\
$1.0 \%$ & 4 & 16 & 35 & 62 & 97 \\
$2.0 \%$ & 1 & 4 & 9 & 16 & 25 \\
$2.5 \%$ & 1 & 3 & 6 & 10 & 16
\end{tabular}

4-c $\quad 90 \%$ Confidence Leve 1

\begin{tabular}{rrrrrr}
$P$ & & & & & \\
$P$ & $1 \%$ & $2 \%$ & $3 \%$ & $4 \%$ & $5 \%$ \\
\hline $0.5 \%$ & 11 & 44 & 98 & 174 & 271 \\
$1.0 \%$ & 3 & 11 & 25 & 44 & 68 \\
$2.0 \%$ & 1 & 3 & 7 & 17 & 17 \\
$2.5 \%$ & 1 & 2 & 4 & 7 & 11
\end{tabular}

4-d $\quad 85 \%$ Confidence Leve 1

\begin{tabular}{rrrrrr} 
& & & & & \\
$\mathrm{P}$ & $1 \%$ & $2 \%$ & $3 \%$ & $4 \%$ & $5 \%$ \\
\hline $0.5 \%$ & 9 & 34 & 75 & 133 & 208 \\
$1.0 \%$ & 3 & 9 & 79 & 34 & 52 \\
$2.0 \%$ & 1 & 3 & 5 & 9 & 13 \\
$2.5 \%$ & 1 & 2 & 3 & 6 & 9
\end{tabular}


If no measurable movements occur prior to production, the problem is relatively simple, since, barring any unusual occurrences, all movements determined following initiation of production are assumed to result from the production. If movements are measured during the pre-production period, these movements are extrapolated into the production period to form the "baseline." The movements attributable to geothermal sources are then assumed to be the total measured movements after production, minus the "baseline" movements. Although this approach is simple, its application may not be so simple because movements cannot be expected to be the same at all bench marks and the rate of movements will vary with time. Plotting of results (see Appendix E, Figure E-4) may be helpful in visualizing the data, but a statistical approach will usually be indicated.

The basic statistical approach applicable to this problem is to perform a regression analysis for the pre-production data; to use the resulting regression model to estimate the baseline movement at some time, $t$, during the production period; and to compare this base line estimate with the measured total movement at that time. The difference between the estimated base line value and the measured total value is the assumed value of movement associated with geothermal production. If this difference is small, it is possible that the base line movements have deviated from the predicted model. A simple statistical approach may be used to determine the probability that a measured production value belongs to the family of movements recorded before production. The applicable statistical procedures and a numerical example are presented in the following sections. Also presented is a method for determination of the statistical correlation between measured rate of subsidence and rate of geothermal production.

\section{F.3.1 Regression Models}

If observation of two variables are available, correlation between the two variables can be estimated by statistical analysis of the data. Generally employed for this purpose are regression models which provide 
a relationship for predicting average values of one variable for various values of the other. The strength of the relationship is indicated by a correlation coefficient obtained from the results of regression anaiysis.

A general regression model for two variables, $X$ and $Y$, can be represented as follows:

$$
Y_{i}=f\left(X_{i}\right)+E_{i}
$$

where: $\quad x_{i}=i^{\text {th }}$ value of $x$

$$
\begin{aligned}
Y_{i} & =\text { value of } Y \text { corresponding to } X_{i} \\
f\left(X_{i}\right) & =\text { functional form of the regression equation } \\
E_{i} & =\text { a random error term }
\end{aligned}
$$

The random error terms are generally assumed to be independent and normally distributed with a mean value equal to zero and a variance, $\sigma^{2}$. Though the functional form $f\left(x_{i}\right)$ can be any complex form, linear or quadratic functions are usually satisfactory approximations. The linear and quadratic regression models are represented by equations $1 \mathrm{a}$ and $1 \mathrm{~b}$, respectively:

$$
\begin{aligned}
& Y_{i}=\beta_{0}+\beta_{1} X_{i}+E_{i} \\
& Y_{i}=\beta_{0}+\beta_{1} X_{i}+\beta_{2} X_{i}{ }^{2}+E_{i}
\end{aligned}
$$

Where $\beta_{0}, \beta_{1}$, and $B_{2}$ are regression coefficients, and $Y_{i}, X_{i}$, and $E_{i}$ are as defined above.

The regression analysis begins by estimating the regression coefficients and the variance of the random error term from sample data. In this report, sample data are a series of subsidence measurements, and the linear regression model is assumed to be a satisfactory approximation for this data. 
The least squares estimators of the regression coefficients for the linear model are given by:

$$
\begin{aligned}
& b_{1}=\frac{\sum_{i=1}^{n}\left(X_{i}-\bar{X}\right)\left(Y_{i}-\bar{Y}\right)}{\sum_{\substack{i=1 \\
n}}^{n}\left(X_{i}-\bar{X}\right)^{2}} \\
& b_{0}=\bar{Y}-b_{1} \bar{X}
\end{aligned}
$$

where:

$$
\begin{aligned}
b_{0}, b_{1} & =\text { estimated values of } \beta_{0} \text { and } \beta_{1}, \text { respectively } \\
\bar{X} & =\text { mean value of } X \\
\bar{Y} & =\text { mean value of } Y \\
n & =\text { number of measurements taken }
\end{aligned}
$$

The random error, $E_{i}$, is assumed to have a mean value equal to zero with a variance of $\sigma^{2}$. An unbiased estimator of this variance of the random error term is:

$$
s^{2}=\frac{\Sigma\left(y_{i}-b_{0}-b_{1} x_{i}\right)^{2}}{n-2}
$$

\section{F.3.2 Separating Baseline Movements}

Two statistical procedures for separating baseline movements from movements measured by monitoring during production are presented here. In both procedures, baseline movements are represented by a linear regression model, and a statistical analysis is used to determine the probability that the movements measured after production belong to the model of baseline movements.

The first procedure is used for comparing a single determination (or the average of a group of determinations) of movement at some time during production with an estimate of the baseline value at that time. The 
procedure consists of estimating the average value of the baseline movement at the time the production measurement was made, and of determining intervals about this average corresponding to one or more confidence levels. If the production movement lies within an interval, it is assumed with the confidence level corresponding to that interval that the production measurement belongs to the baseline model, i.e. that geothermal production has not affected the pattern of movement represented by the baseline model. Following is an outline of this procedure:

1. With $x_{h}$ being the time when the production measurement was made, an estimate of the average value of the baseline movement at that time is determined from:

$$
\hat{y}_{h}=b_{0}+b_{1} x_{h}
$$

where: $\quad \hat{Y}_{h}=$ estimated average value of the baseline movement at time $x_{h}$

$$
\begin{aligned}
b_{0}, b_{1}= & \text { estimates of } \beta_{0} \text { and } \beta_{1} \text { for the baseline } \\
& \text { data, as determined by Equations } 3 \text { and } 2, \\
& \text { respectively. }
\end{aligned}
$$

Note that Equation 5 is of the form of Equation la with the random error, $E$, omitted. Since the random error was defined as having an average value of 0 , Equation 5 will give an estimate of the average value of the estimated base line value at time $x_{h}$.

2. Select one or more significance levels, $\alpha$, for the analysis, say 1,5 , and 10 percent. The significance level is equivalent to stating that the level of confidence for the interval determined is $(1-\alpha)$ percent, i.e., 99,95 , and 90 percent for the significance levels of 1,5 , and 10 percent, respectively.

3. Determine the intervals, corresponding to these levels of confidence, that the measured production movement should lie within to be considered characteristic of baseline movements. Each interval is determined as follows: 


$$
\hat{Y}_{h}-t S \leq Y_{h} \leq \hat{Y}_{h}+t S
$$

where: $\quad t=$ the "Student's $t$ distribution" corresponding to $\left(1-\frac{\alpha}{2}\right.$ ) and $n-2$. (The mechanics of determining " $t$ " and of using the distribution table can be found in any basic statistics text book)

$n=$ number of data points used in determining the regression model for baseline movements

$\alpha=$ the significance level selected

$Y_{h}=$ the measured movement during production at time $X_{h}$

$S=+\sqrt{S^{2}}$, with $S^{2}$ determined by Equation 4

The second procedure is used for comparing a series 'of determinations of movements at successive measurement rounds during production with estimates of baseline values for the time of each round. Following is an outline of this second procedure:

1. Using Equation 5, determine the estimated average baseline value for the time, $x_{h}$, of each of the production test rounds.

2. Determine simultaneous prediction intervals for each of the average baseline values determined in 1 , above. Each interval is determined as follows:

$$
\hat{Y}_{h}-\left(S^{*} \cdot S\right) \leq Y_{h} \leq \hat{Y}_{h}+\left(S^{*} \cdot S\right)
$$

where: $\quad \hat{\gamma}_{h}=$ the estimated average value of the basel ine movement at each time $x_{h}$

$$
\begin{aligned}
S^{*}= & +\sqrt{m \times F} \\
m= & \text { the number of production test rounds } \\
F= & \text { the "F distribution" corresponding to } \\
& (1-\alpha), m, \text { and }(n-2) \\
S= & \text { the standard distribution of } Y_{h} \\
n= & \text { number of data points used in determining } \\
& \text { the regression model for baseline movements } \\
Y_{h}= & \text { the measured movement during production } \\
& \text { at each time } X_{h} \\
\alpha= & \text { the significance level selected }
\end{aligned}
$$


If each production measurement lies within the prediction interval for the corresponding time of measurement, it is assumed with the confidence level corresponding to that interval that the production measurements belong to the baseline model, i.e., that geothermal production has not affected the pattern of movements represented by the baseline model.

\section{F.3.3 Numerical Example}

The following example illustrates the application to subsidence monitoring of the statistical procedures described in Section F.3.2.

1. Assume that the data in the following table represents the results of measurements of vertical movements during a monitoring problem. For simplification, it is assumed that measurements were made at six months intervals, and the measurements of vertical movements have been expressed as centimeters per six months since the immediately preceding measurement, i.e. not cummulative.

$x=$ time in months since the
beginning of monitoring

6

12

18

Pre- $\quad 24$

production 30 period (baseline)

36

42

48

Production period
54

60

66

$$
\begin{array}{r}
Y=\begin{array}{r}
\text { Rate of subsidence at } \\
X \text { in } \mathrm{cm} / 6 \text { morths }
\end{array} \\
\hline
\end{array}
$$

\section{5}

0.8

1.2

1.0

1.4

1.7

1.4

\section{0}

2.5

2.7

2.6

3.2 
2. Calculation of the regression model for the pre-production data by:

$$
Y-\beta_{0}+\beta_{1} X+E_{j}
$$

Estimating $\beta_{0}$ and $\beta_{1}$ :

$$
\begin{aligned}
& \sum_{i=1}^{n}\left(x_{i}-\bar{X}\right)\left(Y_{i}-\bar{Y}\right) \\
& b_{1}=\frac{i=1}{\sum \sum\left(X_{i}-\bar{X}\right)^{2}} \\
& b_{1}=0.028 \\
& i=1 \\
& b_{0}=\bar{Y}-b_{1} \bar{X} \\
& b_{0}=0.47
\end{aligned}
$$

Calculations of variance:

$$
s^{2}=\frac{\sum\left(Y_{i}-b_{0}-b_{j} X_{j}\right)^{2}}{n-2} \quad s^{2}=0.042
$$

3. Assume that a single production measurement is to be compared to the pre-production model, and that this is the value of $Y=2.0$ at $X=48$, the first measurement following the beginning of production. Then calculate the estimate of the average value, the standard deviation, and the "Student's $t$ " from:

$$
\begin{aligned}
& \hat{Y}_{h}=b_{0}+b_{1} X_{h} \\
& \hat{Y}_{h}=0.47+(0.028 .48)=1.874 \\
& S=+\sqrt{S^{2}}=\sqrt{0.042}=0.205 \\
& t=2.015 \quad \text { (for confidence level of } 0.95 \text { and } n=7, \\
& \text { determined from published } t \text { tables) }
\end{aligned}
$$

Calculate the prediction interval from:

$$
\begin{aligned}
\hat{Y}_{h}-t S & \leq Y_{h} \leq \hat{Y}_{h}+t S \\
1.814- & (2.015 \cdot 0.205) \leq 2.0 \leq 1.814+(2.015 \cdot 0.205) \\
& 1.401 \leq 2.0 \leq 2.227
\end{aligned}
$$

The prediction interval is 1.401 to 2.227 . Since the measured value of 2.0 lies within this interval, the measured value is assumed to be unaffected by geothermal production, with a confidence level of at 
least 95 percent. If desired, a prediction interval could be calculated for a higher confidence level, say 99 percent, to determine whether the measured value would also lie within this narrower interval.

4. Assume that the entire series of five production measurements are to be compared to the pre-production model.

Calculate the estimate of the average value at each of the production measurement times from:

$$
\hat{y}_{h}=b_{0}+b_{1} x_{h}
$$

The results are as follows:

\begin{tabular}{|c|c|}
\hline$x_{h}$ & $\hat{\gamma}_{h}$ \\
\hline $\begin{array}{l}48 \\
54 \\
60 \\
66 \\
72\end{array}$ & $\begin{array}{l}1.814 \\
1.982 \\
2.150 \\
2.318 \\
2.485\end{array}$ \\
\hline
\end{tabular}

Determine simultaneous prediction intervals for each of the average baseline values tabulated above from:

$$
\begin{aligned}
& \hat{Y}_{h}-\left(S^{*} \cdot S\right) \leq Y_{h} \leq \hat{Y}_{h}+\left(S^{*} \cdot S\right) \\
& F=5.05 \text { (for confidence level of } 0.95, m=5 \text {, } \\
& \text { and }(n-2)=5 \text {, determined from } \\
& \text { published } F \text { distribution tables) } \\
& S^{*}=+\sqrt{\mathrm{m} \times F}=\sqrt{5 \times 5.05}=5.02 \\
& S=0.205 \text { (as before) }
\end{aligned}
$$

Then, for $\hat{Y}_{h}=1.814$, the interval is:

$$
\begin{gathered}
1.814-(5.02 \cdot 0.205) \leq 2.0 \leq 1.814+(5.02 \cdot 0.203) \\
0.785 \leq 2.0 \leq 2.843
\end{gathered}
$$


Similarly the intervals for the other four times are calculated, with results as follows:

$\begin{array}{lrr}X_{h} & Y_{h} & \\ \overline{48} & \overline{2.0} & \frac{\text { Prediction Interval }}{0.785 \text { to } 2.843} \\ 54 & 2.5 & 0.953 \text { to } 3.011 \\ 60 & 2.7 & 1.121 \text { to } 3.179 \\ 66 & 2.6 & 1.289 \text { to } 3.347 \\ 72 & 3.2 & 1.456 \text { to } 3.514\end{array}$

Since, in all cases, the measured values, $Y_{h}$, lie within the corresponding prediction interval, the measured values are assumed to be unaffected by geothermal production, with a confidence level of at least 95 percent. Again, if desired, simultaneous prediction intervals could be calculated for a higher confidence level, say 99 percent, to determine whether the measured values would also lie within these marrow intervals.

\section{F.3.4 Subsidence and Production Rate Correlation}

Since it may be desirable to estimate the subsidence which may be expected from various approaches to future development of a geothermal field, a determination should be made as to whether or not there is a correlation between the measured subsidence rate to date and the rate of geothermal productions during the period in which the measurements were made. A relatively simple statistical procedure may be used to determine the correlation coefficient between subsidence rate and production rate. A linear regression model of the two rate variables is determined using this form of the equation presented in previous sections:

$$
Y_{t+t_{u}}=\beta_{0}+\beta_{1} X_{t}+E_{t}
$$

where: $\quad x_{t}=$ production rate at some time $t$

$$
\begin{aligned}
Y_{t+t_{u}=} & \text { rate of subsidence at some time } t+t_{u}, \text { where } t_{u} \\
& \text { is an appropriate time interval after which the } \\
& \text { effect of a change in production rate will be } \\
& \text { reflected in a change in the rate of subsidence } \\
B_{0}, E_{1}= & \begin{aligned}
\text { regression coefficients, determined as } \\
\text { previously described }
\end{aligned} \\
E_{t}= & \text { a random error term }
\end{aligned}
$$


The correlation is then calculated using the following equation.

$$
\begin{aligned}
& \sum_{i=1}^{n}\left(X_{i}-\bar{X}\right)\left(Y_{i}-\bar{Y}\right) \\
& =\frac{i=1}{n\left(X_{i}-\bar{X}\right)^{2} \sum_{i=1}^{n}\left(Y_{i}-\bar{Y}\right)^{2} 1 / 2} \\
r & =\text { correlation coefficient } \\
X_{j} & =\text { production rate } \\
Y_{i} & =\text { subsidence rate corresponding to that production rate } \\
\bar{X}, \bar{Y} & =\text { mean values of } X \text { and } Y
\end{aligned}
$$

The range of $r$ is from -1.0 to +1.0 . Higher absolute values of $r$ indicate stronger correlations between $X$ and $Y$. Also, $r^{2}$ indicates the proportion of the total variation in $Y$ explained by $X$.

Below is a simplified example of how data may be used to determine the correlation coefficient between the rate of geothermal production and the rate of subsidence. For purposes of this example, it is assumed that $t_{u}=6$ months.

Time, $t$, in months since the start of geothermal production

12

24

36

48

60

72

84

96 $x=$ Production Rate at time $t$ in

$\mathrm{kg} /$ day $\times 10^{7}$

1.0

1.5

1.5

2.0

3.0

3.0

3.5

3.5
$Y=$ Rate of Subsidence at time $t+6$ in

$\mathrm{cm} / 6$ months

0.4

1.0

1.2

1.6

2.5

2.7

3.4

4.5 
For this example, the regression model of $X$ and $Y$ is calculated as follows:

$$
\begin{aligned}
& \quad Y=\beta_{0}+\beta_{1} X+E \\
& b_{0}=-0.968 \\
& b_{1}=1.318 \\
& \text { variance, } S^{2}=0.192 \\
& \text { Correlation Coefficient } r=0.955
\end{aligned}
$$

Since the value of $r$ is relatively high, there is a positive correlation between the rate of production and the rate of subsidence. The square of $r$ is the percentage of $Y$ (rate of subsidence) that is related to $X$ (rate of production). In this case $r^{2}=91 \%$; therefore, it would be reasonable to estimate future rates of subsidence from the expected future rate of production of the geothermal plant. 


\section{APPENDIX}

REFERENCES AND SELECTE', BIBLIOGRAPHY

Atherton, R. W., et al, 1976, "The Analys is of Subsidence Associated with Geothermal Development", Volume I-Handbook, and Volume IIResearch Report, Reports 5139-1 and 5139-2, Systems Control, Inc., Palo Alto, California.

Bacon, C. F., 1976, "Blowout of a Geothermal Wel1", California Geology, v. 29 , no. 1 , p. 13-17.

Batzle, M. L., and Simmons, G., 1976, "Microfractures in Rocks from Two Geothermal Areas", Earth and Planetary Science Letters, v. 30, p. $71-93$.

Curtin, G., 1973, "Collapsing Soil and Subsidence", Geology, Seismicity and Environmental Impact, Special Publication, Association of Engineering Geologists, p. 89-100.

Dunrud, C. R., 1976, "Some Engineering Geologic Factors Controlling Mine Subsidence in Utah and Colorado", U. S. Geological Survey Paper 969, $39 \mathrm{p}$.

Finnemore, E. J. and Gillam, M. L., 1976, "Compaction Processes and Mathmatical Models of Land Subsidence in Geothermal Areas", Land Subsidence, Proceedings of the Second International

Symposium, IAHS-AIHS-UNESCO, December 13-17, 1976, Anaheim, California, p. 157-166.

Green, J. P., 1973, "An Approach to Analysing Multiple Causes of Subsidence", Geology, Seismicity and Environmental Impact, Special Publication, Association of Engineering Geologists, p. 79-87.

Hatton, J. W:, 1970, "Ground Subsidence of a Geothermal: Field During Exploitation", UN Symposium on the Development and Utilization of Geothermal Resources, Pisa, Geothermics, Special Issue 2, v. 2, p. 1294-1296.

Holzer, T. L., 1976, "Ground Failure in Areas of Subsidence Due to Ground-Water Decline in the United. States", Land Subsidence, Pro ceedings of the Second International Symposium, IAHS-AIHSUNESCO, December 13-17, 1976, Anaheim, California, p. 423-433.

House, P. A., Johnson, P. M., and Jowse, D. F., 1975, "Potential Power Generation and Gas Production from Gulf Coast Geopressure Reservoirs", California University, Lawrence Livermore Laboratory, Report 51813, 40 p.

Johnson, G. H. and Soule, J. H., 1963, "Measurement of Surface Subsidence, San Manuel Mine, Pinal Co., Arizona", U. S. Bureau of Mines, RI 6204.

Kennedy, B. A. and Niermeyer, K. E., 1970, "Slope Monitoring Systems Used in the Prediction of a Major Slope Failure at the Chuquicamata Mine, Chile", Proceedings, Open Pit Mining Symposium, Johannesburg, South Africa, p. 215-225. 
Lee, K. L. and Shen, C. K., "Horizontal Movements Related to Subsidence", Journal of the Soil Mechanics and Foundations Division, Proc. ASCE, SMI, Jan. 1969, p. 139-166.

Leonards, G. A., 1962, Foundation Engineering, McGraw-Hill Book Company, USA, p. 597 .

Lofgren, B. E., 1968, "Analysis of Stresses Causing Land Subsidence", U. S. Geological Survey Professional Paper 600-B, p. B219-B225.

Lofgren, B. E., 1969, "Field Measurement of Aquifer-System Compaction, San Joaquin Valley, Cal ifornia, USA", Land Subsidence, Proceedings, IAHS-AIHS-UNESCO, Tokyo, Japan, p. 272-284.

Lofgren, B. E., 1973, "Monitoring Ground Movement in Geothermal Areas", Hydraulic Engineering and the Environment, Proceedings, Hydrautics Division, ASCE, p. 437-447.

Lofgren, B. E., 1974, "Measuring Ground Movement in Geothermal Areas of Imperial Valley, California", Conference on Research for the Development of Geothermal Energy Resources, Jet Propulsion Laboratories, Pasadena, Calif., p. 128-138.

Lofgren, B. E., 1976, "Hydrogeologic Effects of Subsidence, San y Joaquin Valley, California", Land Subsidence, Proceedings of the Second International Symposium, IAHS-AIHS-UNESCO, December 13-17, 1976, Anaheim, Cal ifornia, p. 113-123.

Lucas, C. V. and James, L. B., 1976, "Land Subsidence and the California Water Project", Land Subsidence, Proceedings of the Second International Symposium, IAHS-AIHS-UNESCO, December 13-17, 1976, Anaheim, California, p. 533-543.

Moffit, F. H. and Bouchard, H., 1975, Surveying, Sixth Edition, Intext Educational Pubiishers, New York, New York, 879 p.

Papadopulos, S. S., et a1, 1975, "Assessment of Onshore GeopressuredGeothermal Resources in the Northern Gulf of Mexico Basin", White, D. E., and Williams, D. L. (eds.), Assessment of Geothermal Resources of the United States--1975: U.S. Geological Survey, Circular 726, p. 125-146.

Poland, J. F., 1969, "Land Subsidence in the Western States Due to Groundwater Overdraft", Proceedings, National Reclamation Association Convention, October, 1969, Spokane, Washington, p. $1-12$.

Poland, J. F., and Davis, G. H., 1969, "Land Subsidence Due to Withdrawal of Fluids", Reviews in Engineering Geology, Geological Society of America, v. 2, p. 187-270. 
Press, F. and Siever, R., 1974, Earth, W. H. Freeman and Company, San Francisco, California 945 p.

Real, C. R., and Bennett, J. H., 1976, "Palmdale Bulge", Cal ifornia Geology, August, 1976, p. 171-173.

Riley, F. S., 1969, "Analysis of Borehole Extensometer Data from Central Cal ifornia", Land Subsidence, Proceedings, IAHSAIHS-UNESCO, Tokyo, Japan, $\bar{p}$. 424-431.

Riley, F. S., 1970, "Land-Surface Tilting Near Wheeler Ridge, Southern San Joaquin Valley, California", U.S. Geological Survey Professional Paper 497-G, 29p.

Stephens, J. C. and Stewart, E. H., 1976, "Effect of Climate on Organic Soil Subsidence", Land Subsidence, Proceedings of the Second InternationaT Symposium, IAHS-AIHS-UNESCO, December 13-17, 1976, Anaheim, California, p. 647-655.

Terzaghi, K., and Peck, R. B., 1967, Soil Mechanics in Engineering Practice, John Wiley \& Sons, Inc., New York, 729 p.

Warde11, K., 1970, "The Effects of Mineral and Other Underground Excavations on the Overlying Ground Surface", AEG Symposium, Geological \& Geographical Problems of Areas of High Population Density, p. 201-217.

White, D. E., 1973, "Characteristics of Geothermal Resources", Kruger, P., and Otte,.C. (eds.), Geothermal Energy: Stanford University Press, Stanford, California, p. 69-94.

White, D. E., and Williams, D. L. (eds.), 1975, "Assessment of Geothermal Resources of the United States--1975": U.S. Geological Survey, Circular. 726, $155 \mathrm{p}$.

Whiting, R. L., 1973, "Possible Effects of Geothermal Water and Steam Production on the Subsurface Environment": Proceedings, 74th National Meeting of AIChE, New Orleans, Paper No. 50B, p. 762-771.

Wilson, J. S., Shepherd, B. P., and Kaufman, S., 1974, "An Analysis of the Potential Use of Geothermal Energy for Power Generation Along the Texas Gulf Coast", Dow Chemical U.S.A., Texas Division, $63 \mathrm{p}$.

Woodward-Clyde Consultants, 1977a, "Subsidence Monitoring Systems for Undermined Areas": unpublished report submitted to the U.S. Bureau of Mines, Denver, by Woodward-Clyde Consultants, San Francisco, Calif., 304 p. 
Woodward-Clyde Consultants, 1977b, "Available Subsurface Instrumentation for Geothermal Subsidence": unpublished report submitted to the Lawrence Berkeley Laboratory, Berkeley, California, by Woodward-Clyde Consultants, San Francisco, Cal ifornia, $83 \mathrm{p}$.

Yerkes, R. F. and Castle, R. 0., 1969, "Surface Deformation Associated with $0 i 1$ and Gas Field Operations in the United States", Land Subsidence, Proceedings, IAHS-AIHS-UNESCO, Tokyo, Japan, v. 7, p. 55-66. 